\title{
Potential for Volcanogenic Massive Sulfide Mineralization at the A6 Anomaly, North-West British Columbia, Canada: Stratigraphy, Lithogeochemistry, and Alteration Mineralogy and Chemistry
}

\author{
Stefanie M. Brueckner ${ }^{1, *}$, Gregory Johnson ${ }^{1}$, Stephanie Wafforn ${ }^{2}$, Harold Gibson ${ }^{3}$, Ross Sherlock ${ }^{3}$, \\ Christina Anstey ${ }^{2,+}$ and Ken McNaughton $2, \ddagger$
}

check for updates

Citation: Brueckner, S.M.; Johnson, G.; Wafforn, S.; Gibson, H.; Sherlock, R.; Anstey, C.; McNaughton, K. Potential for Volcanogenic Massive Sulfide Mineralization at the A6 Anomaly, North-West British Columbia, Canada: Stratigraphy, Lithogeochemistry, and Alteration Mineralogy and Chemistry. Minerals 2021, 11, 867. https://doi.org/ $10.3390 / \min 11080867$

Academic Editors: Steven P. Hollis, Jonathan Cloutier and Jean-Luc Pilote

Received: 1 July 2021

Accepted: 4 August 2021

Published: 11 August 2021

Publisher's Note: MDPI stays neutral with regard to jurisdictional claims in published maps and institutional affiliations.

Copyright: (c) 2021 by the authors Licensee MDPI, Basel, Switzerland. This article is an open access article distributed under the terms and conditions of the Creative Commons Attribution (CC BY) license (https:/ / creativecommons.org/licenses/by/ $4.0 /)$.
1 Department of Earth Sciences, University of Manitoba, Winnipeg, MB R3T 2N2, Canada; johns177@myumanitoba.ca

2 Four Bentall Centre, Pretivm Resources Inc., Vancouver, BC V7X 1L4, Canada; swafforn@pretivm.com (S.W.); christina.anstey@brixtonmetals.com (C.A.); kenmcnaughton123@gmail.com (K.M.)

3 MERC, Harquail School of Earth Sciences, Laurentian University, Greater Sudbury, ON P3E 2C6, Canada; hgibson@laurentian.ca (H.G.); rsherlock@laurentian.ca (R.S.)

* Correspondence: stefanie.brueckner@umanitoba.com

$+\quad$ Now at: Brixton Metals Corporation, Vancouver, BC V6C 1T2, Canada.

$\ddagger \quad$ Now at: P2 Gold Inc., Vancouver, BC V6C 2G8, Canada.

Abstract: The Middle Jurassic A6 Anomaly is located $30 \mathrm{~km}$ southeast of Eskay Creek, north-central British Columbia and consists of thick, altered felsic igneous rocks overlain by a mafic volcanosedimentary package. Lithogeochemistry on igneous rocks, X-ray diffraction on altered felsic units, and electron probe microanalysis and secondary ion mass spectrometry on illite and quartz were applied to explore the volcanogenic massive sulfide (VMS) potential, characterize alteration, and determine fluid conditions at the A6 Anomaly. Lithogeochemistry revealed calc-alkaline rhyodacite to trachyte of predominantly FII type, tholeiitic basalts with $\mathrm{Nb} / \mathrm{Yb}<1.6$ (i.e., Group A), and transitional to calc-alkaline basalts and andesites with $\mathrm{Nb} / \mathrm{Yb}>2.2$ (i.e., Group B). The felsic units showed weakly to moderately phyllic alteration (quartz-illite with minor orthoclase and trace chloritepyrite-calcite-barite-rutile). Illite ranged in composition from illite/smectite ( $\mathrm{K}=0.5-0.69 \mathrm{apfu})$ to almost endmember illite ( $\mathrm{K}=0.69-0.8 \mathrm{apfu}$ ), and formed from feldspar destruction by mildly acidic, relatively low temperature, oxidized hydrothermal fluids. The average $\delta^{18} \mathrm{O}$ composition was $10.7 \pm 3.0 \%$ and $13.4 \pm 1.3 \%$ relative to Vienna Standard Mean Ocean Water for illite and quartz, respectively. Geothermometry involving illite composition and oxygen isotope composition on illite and quartz yielded average fluid temperatures of predominantly $200-250{ }^{\circ} \mathrm{C}$. Lithogeochemical results showed that the A6 Anomaly occurred in a late-Early to Middle Jurassic evolving back-arc basin, further east then previously recognized and in which transitional to calc-alkaline units formed by crustal assimilation to enriched Mid-Ocean Ridge Basalt (EMORB) (i.e., felsic units, Group B), followed by thinning of the crust resulting in tholeiitic normalized MORB basalts (i.e., Group A) with a minor crustal component. The alteration assemblage is representative of distal footwall alteration, and metal transport in this zone was limited despite favorable temperature, $\mathrm{pH}$, and redox state, indicating a metal depleted source (i.e., felsic units).

Keywords: lithogeochemistry; alteration mineralogy and mineral chemistry; illite chemistry; oxygen isotope; geothermometry; exploration; stratigraphy; VMS; north-central British Columbia

\section{Introduction}

North-west British Columbia is a highly metal-endowed region, often colloquially dubbed the "Golden Triangle". The area hosts several high-grade mines and deposits including the Kerr-Sulphurets-Mitchell (KSM) porphyry camp, the epithermal Au Brucejack 
mine, and the Eskay Creek volcanogenic massive sulfide (VMS) deposit, among others. Mineralization in the area is hosted predominantly within the Lower to Middle Jurassic Hazelton Group (e.g., [1-3]). Although the area has been the focus of regional campaigns (e.g., [4-6]), steep terrain, poor exposures outside of the alpine and rapid facies changes in the volcanic units has made stratigraphic correlations between areas difficult, and hence, hindered exploration efforts to identify exploration targets. Among the known deposits in the region, the majority are porphyry and epithermal deposits formed in a volcanic arc in the Lower Jurassic (e.g., $[1,7,8])$. In contrast, known VMS deposits are relatively rare and occur predominantly in the southern portion of the "Golden Triangle" (e.g., Triassic Granduc deposit, Jurassic Anyox and Eskay Creek deposits; [9,10]). Nevertheless, more VMS occurrences haven been assumed for the area (e.g., [11,12]). Of particular interest for VMS exploration are lithologies in the Iskut River Formation of the Upper Hazelton Group, as these are interpreted to have formed, in part, in a late-Early to Middle Jurassic back arc rift which is a favorable VMS setting (e.g., [13-17]). The anomalous Au-rich Eskay Creek deposit is interpreted to have formed within a north-south trending back-arc rift (i.e., Eskay rift; $[10,18,19])$ in the Middle Jurassic. Exploration efforts targeting VMS systems have been following the trend of this rift but with little success so far.

In 2018 and 2019, Pretivm Resources Inc. targeted the A6 Anomaly, a greenfields exploration prospect, located about $15 \mathrm{~km}$ north northeast of the Brucejack mine and $30 \mathrm{~km}$ southeast of the Eskay Creek deposit. The targeting was based on: (1) the occurrence of the A6 Anomaly within strata of the Iskut River Formation [5]; (2) the volcanic-sedimentary lithologies indicating a submarine environment susceptible to VMS mineralization (e.g., [20-22]); and (3) its stratigraphic similarities on the surface (i.e., (pillow) basalt flows and sills alternating with mudstones) to the anomalously Au-rich Eskay Creek VMS deposit. Drilling in 2019 further revealed hydrothermally altered felsic flows and volcaniclastic rocks beneath the mafic volcano-sedimentary package [23]. U-Pb geochronology on the felsic strata confirmed the stratigraphic position of the A6 Anomaly within the Iskut River Formation of the Upper Hazelton Group.

Here, we present the stratigraphic results from logging ten drill cores from the A6 Anomaly and combine these results with detailed lithogeochemistry of the felsic, intermediate, and mafic igneous rocks, and alteration mineralogy and chemistry of the altered felsic units. The igneous rocks were analyzed for whole rock lithogeochemistry, and the altered felsic rocks underwent further analyses with focus on mineral assemblage (transmitted and scanned electron microscopy), mineral chemistry (electron microprobe analyses), and stable isotope geochemistry (i.e., oxygen isotopes via secondary ion mass spectrometry) to test the VMS potential of the A6 Anomaly and determine the conditions responsible for the hydrothermal alteration in order to provide a spatial context of the altered felsic flows (e.g., distal/proximal footwall alteration, hanging wall alteration). The stratigraphy provides insights into a poorly known area in the Iskut river region and adds to the stratigraphic framework of the Upper Hazelton Group. Moreover, stratigraphy and lithogeochemistry provide constraints on the tectonic setting of the A6 Anomaly, which extends late-Early to Middle Jurassic rifting $[10,18,19]$ further to the east than previously mapped. This contribution also characterizes the felsic, intermediate, and mafic igneous rocks geochemically based on their major, minor, and trace element geochemistry and uses these results to determine if the igneous lithological units are barren or fertile to VMS mineralization. Finally, alteration mineralogy and chemistry including mineral chemistry and $\mathrm{O}$ isotope geochemistry is used to quantify the degree of alteration (i.e., mass changes), define the alteration assemblage in the altered felsic units, and determine the hydrothermal fluid conditions $(\mathrm{T}, \mathrm{pH})$ responsible for the alteration. This study makes a significant contribution to the ongoing exploration efforts in north-central British Columbia, provides new stratigraphic, geochemical, and mineralogical insights into an under-studied area of the Iskut river region, and applies macro- to micro-scale techniques to determine the potential of the A6 Anomaly for VMS mineralization, which can be applied to other VMS greenfield exploration targets in the region and globally. 


\section{Geological Setting}

\subsection{Regional Geological Setting}

The North American Cordillera in western Canada is made up of five tectonic realms that are from east (oldest) to west (youngest): Ancestral North America (Laurentia), Intermontane Belt (peri-Laurentia) with Coastal Plutonic Complex, Arctic and Insular Terranes, and late accreted Pacific Terranes (Figure 1; e.g., $[8,24]$ ). The latter is more prominently developed in Alaska, and hence, not shown in Figure 1. Of these predominantly northsouth trending terranes, the Intermontane Belt is a complex collage of arcs, back-arcs, rifts, collisional environments, and sedimentary basins formed during the late-Paleozoic to early-Mesozoic (e.g., [8,25-27]). The largest of these terranes is the Stikine terrane (Stikinia) that extends for ca. $1000 \mathrm{~km}$ from southern British Columbia to the Yukon, flanked to the east by the Cache Creek terrane and to the west by the Coastal Plutonic Complex (Figure 1). Stikinia consists of Paleozoic to Mesozoic bimodal volcanic rocks, their plutonic counterparts, and siliciclastic and biologic sedimentary rocks (e.g., $[4,6,28,29])$. Stratigraphically, four assemblages and groups make up Stikinia, which are, from oldest to youngest: (1) Paleozoic Stikine assemblage, consisting of volcano-sedimentary rocks and limestone; (2) Triassic Stuhini Group, consisting of mostly mafic volcano-sedimentary rocks; (3) Early to Middle Jurassic Hazelton Group, consisting of mafic to felsic volcano-sedimentary rocks; and (4) Middle Jurassic to Early Cretaceous Bowser Lake Group, consisting of sedimentary rocks; (e.g., [4,6,12,28-31]).

Legend

Coast Plutonic Complex

Arctic-Northeast Pacific: Insular

Alexander

Wrangelia

Peri-Laurentia (Intermontane)

Cache Creek

Quesnelia

Stikina

Yukon-Tanana

Slide Mountain

Ancestral North America (Laurentia) Deformed Belt

Laurentian Platform and Craton

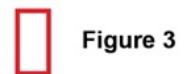

- Border Provinces/Territories

- - Border Canada-USA

AB Alberta BC British Columbia

NWT Northwest Territories YK Yukon

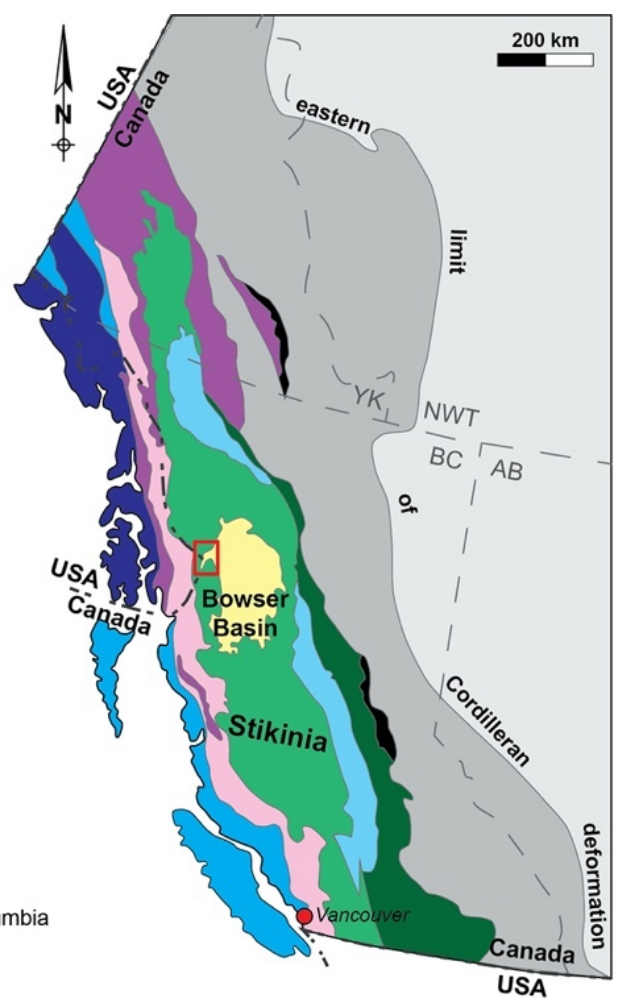

Figure 1. Simplified geological map of the Canadian Cordillera $[8,9]$.

The Paleozoic Stikine assemblage is not well exposed in Stikinia; it forms, however, the basement for younger arc-related strata [12]. The Upper Triassic Stuhini Group consists of several units that are not well defined stratigraphically due to difficulties to correlate these units continuously and the occurrence of similar lithological units at different stratigraphic levels (Figure 2; $[8,12])$. The units formed in marine environments based on fauna in sedimentary rocks [19]. The Hazelton Group lies unconformably to disconformable above the Stuhini Group, and has an Early to Middle Jurassic age (Figure 2; $[4,6,12,28,30,31]$ ), although an age as old as Upper Triassic has been postulated by Nelson et al. [8]. The 
stratigraphy of the Hazelton Group and its nomenclature has been inconsistent. Recent modifications by Gagnon et al. [4], Lewis [5], and Nelson et al. [6] form the basis for the summary given here. The Hazelton Group is divided into Lower and Upper Hazelton Group (Figure 2). These units together with the Stuhini Group host several precious and base metal mineral deposits in north-central British Columbia (e.g., Granduc and Snip in Stuhini Group; Anyox, KSM, Snowfield, Brucejack, Eskay Creek, Treaty Glacier in Hazelton Group). This exceptional metal endowment makes the Hazelton Group a prime target for exploration.

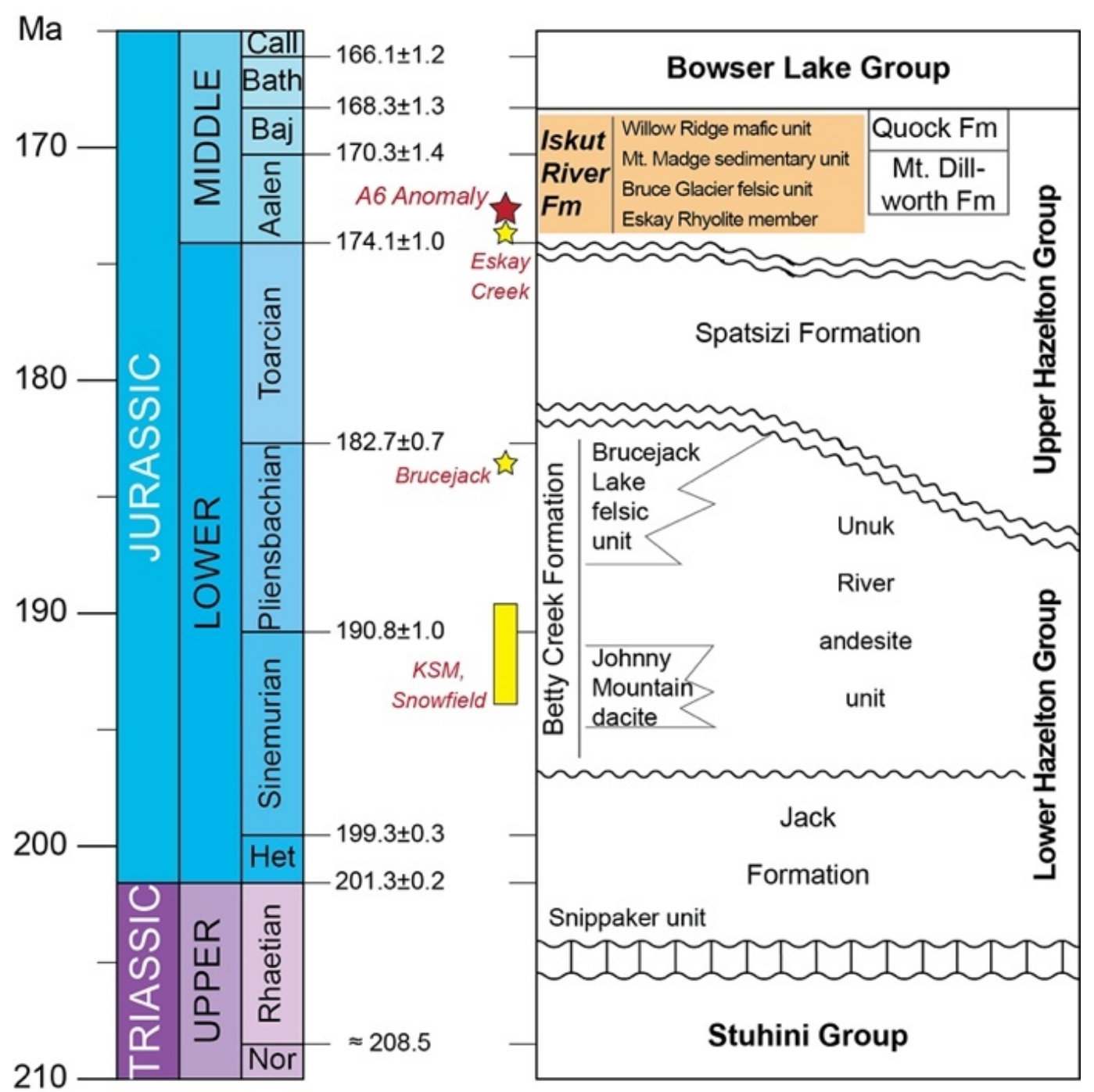

Figure 2. Stratigraphy of the Hazelton Group in the Iskut River area. Yellow stars and bar show the age of the deposits in this region, while the red star shows the U-Pb zircon age of altered felsic flows at the A6 Anomaly, Iskut River Formation (light orange is the stratigraphic level of interest in this study); see Table 1 for more detailed information on the age of mineral deposits, modified after Nelson et al. [6], with a stratigraphic chart after Cohen et al. [32]. Abbreviations: Baj-Bajocian, Bath-Bathonian, Call—Callovian, Fm-Formation, Het-Hettangian, Nor-Norian.

The stratigraphy of the Hazelton Group is complex with lateral facies variations, which make spatial correlations difficult. A basal conglomerate defines the lowermost Hazelton Group (i.e., Jack Formation), which is unconformably in contact with the underlying Triassic Stuhini Group. This unconformity is overlain by fine to coarse, intermediate volcaniclastic rocks (tuff to breccia) and andesitic to dacitic flows (i.e., Betty Creek Formation; [4,6,9,12,28,30,33]). Macdonald et al. [12] reported local felsic flows and volcaniclastic rocks above the intermediate volcanic rock succession. The uppermost Lower 
Hazelton Group is "capped" by a turbiditic siltstone to sandstone and heterolithic cobble conglomerate [12]. Numerous hydrothermal deposits are hosted in the volcanic and volcaniclastic sequences of the Lower Hazelton Group, including the Au-rich epithermal Brucejack mine and the KSM porphyry deposits (Figures 2 and 3, Table 1; [1,7,33-35]). The Lower Hazelton Group is interpreted as an arc complex similar to the modern-day Philippine archipelago, characterized by volcanic and volcaniclastic sequences $[8,28]$. The contact between Lower and Upper Hazelton Group has not been described in detail; it is reported to be commonly obscured by deformation, not exposed, or to display a conformable to disconformable contact [6]. The late-Early to Middle Jurassic Upper Hazelton Group includes a bimodal volcanic-sedimentary rift sequence of tholeiitic coherent and pillow basalt with lesser rhyolite, sandstone, and siltstone beds, especially near the top of the stratigraphic sequence (i.e., Iskut River Formation; $[4,6,9,11,12,36])$. The north-south trending back-arc rift (i.e., Eskay rift) hosts the Au-rich Eskay Creek VMS deposit. The deposit was mined from 1995 to 2001 by Homestake Canada, has historic grades of $1.9 \mathrm{Mt}$ @ $60.2 \mathrm{~g} / \mathrm{t} \mathrm{Au}, 2652 \mathrm{~g} / \mathrm{t} \mathrm{Ag}, 3.2 \mathrm{wt} \% \mathrm{~Pb}, 5.2 \mathrm{wt} \% \mathrm{Zn}$ and $0.7 \mathrm{wt} \% \mathrm{Cu}$ [37], current open pit (indicated and inferred) resources of 27,070 kt @ 6.6 g/t Au and $157 \mathrm{~g} / \mathrm{t} \mathrm{Ag} \mathrm{[38],} \mathrm{and}$ is currently owned by Skeena Resources Inc. Eskay Creek is characterized by thoeleiitic rhyolite flows overlain by thick basaltic, pillowed flows, and pillow breccia intercalated with black argillite [10-12,28,36,37,39-41]. East of the rift, Upper Hazelton Group lithofacies are characterized by epiclastic siltstones, sandstones, and conglomerates of the Spatzisi Formation and/or laterally extensive volcanic rocks of the Mt. Dilworth Formation $[4,6]$ that were deposited in a submarine environment. Intercalated black mudstone, grey siltstone, and brown tuff beds of the Middle to Late Jurassic Quock Formation conformably overlie the Iskut River Formation [29,31]. The epiclastic sediments of the Quock Formation mark background sedimentation and end of proximal volcanism prior to docking of Stikinia with the Cache Creek terrane. Fine- to coarse-grained siliciclastic sedimentary rocks of the Bowser Lake Group, which mark the onset of deposition of detritus shed from Stikinia-Cache Creek orogenic welt, overlie the Quock Formation and are most abundant in the Bowser Basin to the east [31]. The Hazelton Group underwent subgreenschist facies metamorphism and deformation including thrusting, faulting, and folding during the Cretaceous, when outboard terranes accreted onto the western Laurentian margin $[8,28]$. Cenozoic dikes crosscut the older stratigraphy in the Iskut river area.

Table 1. Age of mineral deposits in vicinity of study area and of the A6 Anomaly.

\begin{tabular}{cccc}
\hline Deposit/Prospect & Age [Ma] & Lithology & Reference \\
\hline KSM & $193.9 \pm 0.5$ to $190.3 \pm 0.8$ & Altered and mineralized diorite & [7,34,42] \\
Snowfield & $189.6 \pm 2.2$ & Porphyry & {$[43]$} \\
Brucejack & $\leq 184$ & Porphyritic lava flow & {$[1,44]$} \\
A6 Anomaly & $172.0 \pm 1.7$ & Felsic volcanic and volcaniclastic rocks (BR-65) & [45] \\
& $176.4 \pm 0.94^{*}$ & Heterolithic sandstone (BR-38) & \\
Eskay Creek & $177.0 \pm 1.2^{*}$ & Intermediate volcaniclastic rock (E flank from BR-69) & [2] \\
\hline
\end{tabular}

* Represent maximum deposition age due to the siliciclastic and volcaniclastic nature of sample.

\subsection{Stratigraphy of the A6 Anomaly}

The A6 Anomaly area is located circa $15 \mathrm{~km}$ north northeast of the epithermal Au Brucejack mine and approximately $30 \mathrm{~km}$ southeast of the Au-rich VMS Eskay Creek deposit (Figure 3a). Geochronological data by Pretivm Resources Inc. [45] revealed U$\mathrm{Pb}$ zircon ages of $172.0 \pm 1.7 \mathrm{Ma}$ for altered felsic flows beneath the retreating glacier and maximum deposition ages for heterolithic sandstone and intermediate lapilli tuff of $176.4 \pm 0.94 \mathrm{Ma}$ and $177.0 \pm 1.2 \mathrm{Ma}$ on the $\mathrm{W}$ and E flank, respectively (Table 1). These ages overlap with lithologies in the Upper Hazelton Group and felsic volcanic and volcaniclastic units in the Iskut River Formation (Figure 2). 
The stratigraphy of the A6 Anomaly is based on detailed field observations and core logging of ten drill holes done in 2018 and 2019 [23]. At the A6 Anomaly, several stratigraphic units have been identified including: (1) basaltic flows and/or lapilli tuff and tuff altered to chlorite \pm hematite; (2) altered felsic flows with minor volcaniclastic rocks occurring only beneath the retreating glacier; (3) a heterogeneous epiclastic sequence of siltstone to conglomerate; (4) massive to bedded mudstone that alternates with (5) basaltic to andesitic flows and sills and their volcaniclastic counterparts; and (6) mafic intrusions cross-cutting the aforementioned lithologies (Figure 4).

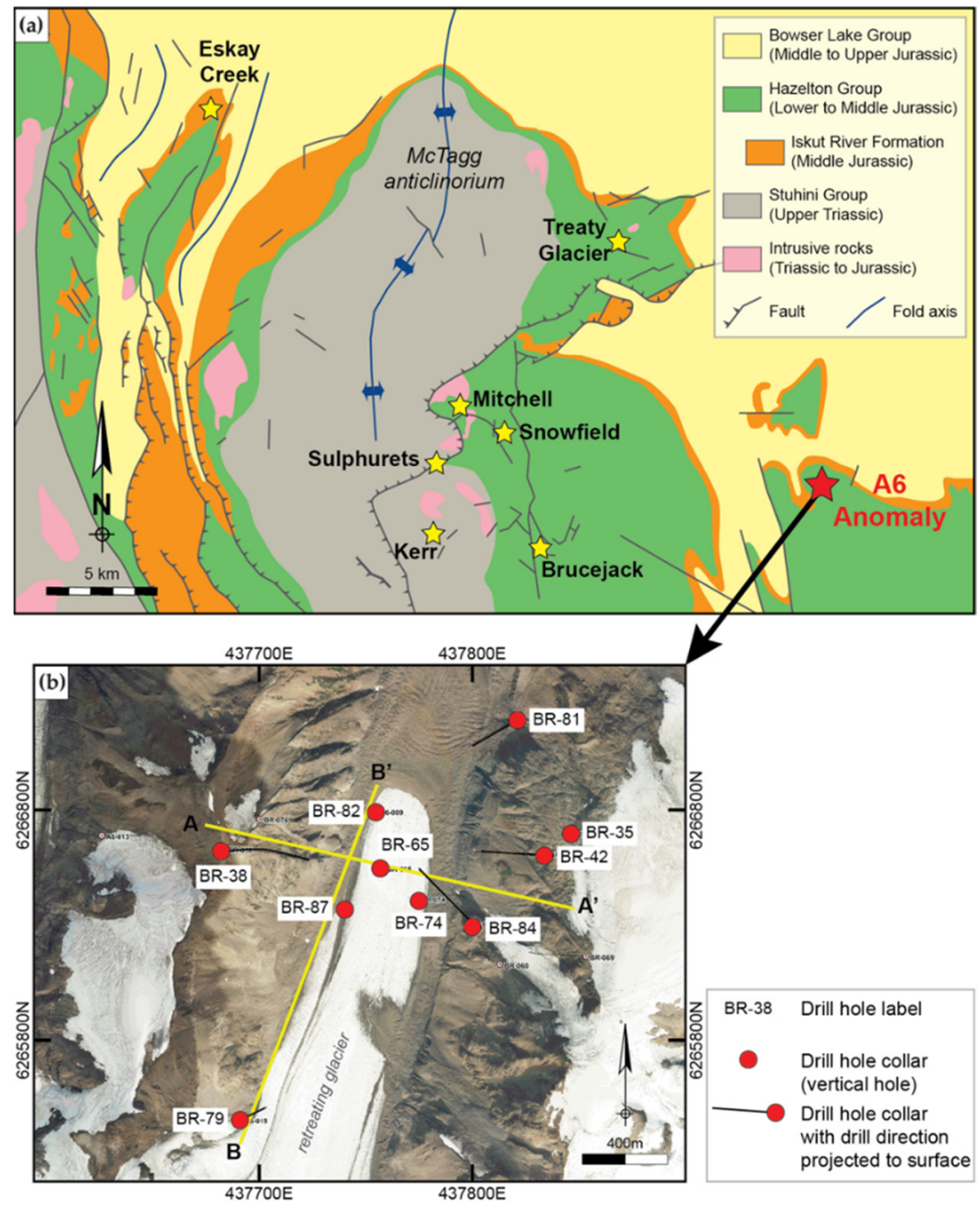

Figure 3. Geological map of study area and map of drill holes at A6 Anomaly. (a) Detailed geological map of Iskut River region with location of Eskay Creek, KSM, Snowfield, Brucejack, and Treaty Glacier deposits (yellow stars) and the A6 Anomaly (red star). In Map b (modified after Lewis [5] and Kirkham and Margolis [34]), the black arrow highlights (b) the location of drill holes at the A6 Anomaly investigated in this study; cross sections for A-A' and B-B' are shown in Figure 4. Their stratigraphic section of each drill hole is shown Figure 4, Easting and Northing after UTM NAD83 zone 9 . Details about geographic location and depth for each drill hole are summarized in Supplementary Materials Table S1a).

The oldest lithologies are strongly chlorite- and hematite altered, aphanitic basaltic flows, or fine-grained tuff to lapilli tuff (Figure 5a,b) that are at least $160 \mathrm{~m}$ thick and occur beneath altered felsic flows below the retreating glacier (Figure 4a). The stratigraphic position of this unit is unclear, since chlorite and hematite alteration are typical for the Betty Creek Formation of the Lower Hazelton Group (e.g., [4-6]). However, fine-grained tuffs have been reported in the Upper Hazelton Group at Eskay Creek, specifically below the altered Eskay rhyolite in the Lower Footwall unit (e.g., [40,41]). The contact towards overlying altered flows is sharp and marked by brittle deformation. 


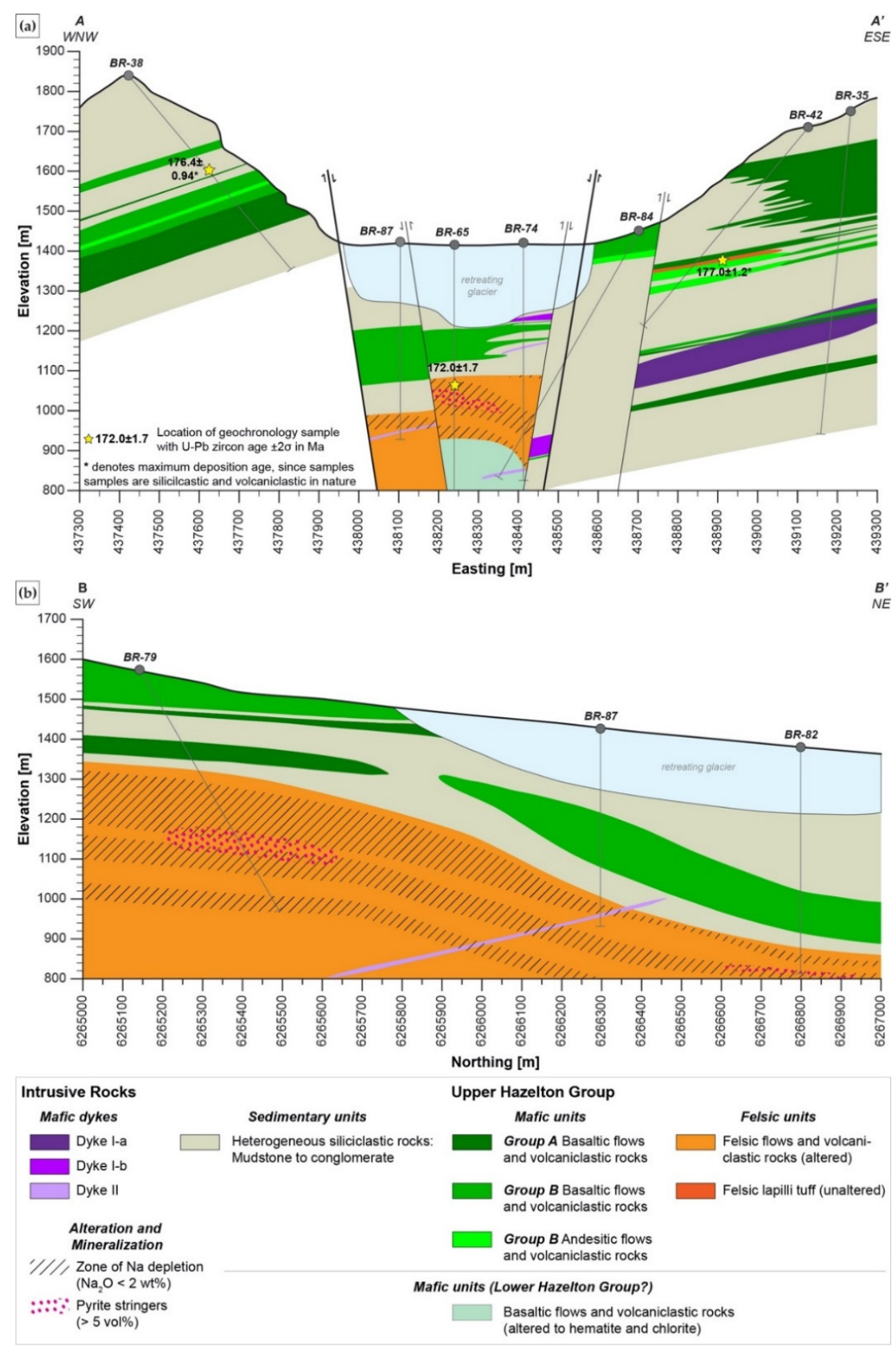

Figure 4. Stratigraphic cross-sections at the A6 Anomaly, locations are shown in Figure 3b. (a) A-A' is running perpendicular to NNW-NW dipping strata and is based on drill holes BR-35, -38, -42, -65, -74, and -87; there is a series of normal faults that form a horst and graben structure, of which age data are from [45]. (b) B-B' is a stratigraphic long section parallel to the retreating glacier based on stratigraphy in drill holes BR-79, -82, and -87. (modified after Brueckner [23]).

Massive, green to light-colored, felsic flows (Figure $5 \mathrm{c}-\mathrm{f}$ ), partly with flow banding (Figure 5d) and perlitic texture, are locally recognized (Figure 4) and decrease in thickness toward the north. The flows are at least $50 \mathrm{~m}$ thick and can exceed $200 \mathrm{~m}$ in the southwest (e.g., BR-79 in Figure 4b). They are altered to quartz-sericite with minor chlorite (Figure $5 c-f$ ) and can have disseminated pyrite or pyrite stringers (Figure $5 \mathrm{c}$ ) that occur in discreet zones (Figure 4). Flow banding is common in particular towards the upper contact; however, flow lobes and hyaloclastite are absent. The felsic unit can have up to $5 \mathrm{~m}$ thick clast-bearing tuffs and lapilli tuffs towards the upper contact intercalated with heterolithic epiclastic lithologies, and suggest formation in a flow dome. Contacts are transitional between felsic flows and felsic volcaniclastic rocks. Subangular, rhyolitic clasts are up to $5 \mathrm{~mm}$ large within lapilli tuff and clast-bearing tuff. The matrix is very fine-grained to aphanitic, and 
quartz-sericite alteration occurs, similar to underlying felsic flows. A thin interval of felsic lapilli tuff occurs within a sequence of andesitic tuffs and flows on the east flank. This unit is about $15 \mathrm{~m}$ thick and consists of angular, up to $1 \mathrm{~cm}$ large volcanic clasts in a fine-grained matrix. No sulfide mineralization or distinct alteration was observed. A $177.0 \pm 1.2 \mathrm{Ma}$ $\mathrm{U}-\mathrm{Pb}$ zircon age [45] (Figure $4 \mathrm{a}$ ) suggests it is older than the massive, altered felsic units occurring beneath the retreating glacier.

Above the altered felsic flows and volcaniclastic rocks, a thick (up to $150 \mathrm{~m}$ ) volcanosedimentary package occurs that is intersected in all drill holes (Figure 4). The contact between felsic units, when present, and the epiclastic lithologies, are sharp. The epiclastic comprises polymictic conglomerate grading upward into thinly bedded siltstone to polymictic conglomerates (Figure $5 \mathrm{~g}-\mathrm{j}$ ). The sequence is normally graded and represents turbiditic flows. The pebble to cobble conglomerates, in which grading is either very weak or absent, consists of poorly sorted, polymictic, subround to subangular clasts in either a very-fine grained siltstone (Figure $5 \mathrm{~g}$ ) or a quarzitic sandstone matrix (Figure $5 \mathrm{~h}$ ) that shows no alteration or mineralization. The clasts are both igneous (basaltic, rhyolitic; Figure 5g,h) and epiclastic (mudstone, siltstone: Figure 5h), and the contact to overlying finer grained epiclastic sequences is commonly transitional. Sandstone units are fine- to coarse-grained, can show normal grading, but are rarely bedded internally. Thin sandstone beds within finely bedded, grey siltstone to mudstone beds can occur (Figure 5i,j). Grey siltstone beds are more commonly interbedded with mudstone, in particular upwards in the stratigraphy, and have varying carbonate contents.

The mudstones are massive to bedded, can reach several tens of meters, and are thickest up stratigraphy, in particular on the east and west flank, where they commonly alternate with basalts, sills, and their volcaniclastic counterparts (Figures 4 and 6a,b). Pyrite and occasionally pyrrhotite occur within the mudstones, either as disseminated grains, stringers (Figure 6a), beds parallel to bedding (Figure 6b) or, when occurring as pyrrhotite, within mm-thick quartz-carbonate veinlets. However, mineralization is not pervasive, but rather, is local within the mudstones. Bedding is more prominent in mudstones up in the stratigraphy, where they are the dominating epiclastic unit. Bedded mudstones either alternate with thin siltstone and/or sandstone beds (Figure 5j) or with thin grey to brown siltstone or tuff beds (Figure 6b); the latter texture is prominent in the upper part of the drill holes on the east and west flank and in outcrops on the surface, and is interpreted as the Quock Formation, representing detritus deposition shed from both Stikinia and Cache Creek terranes (e.g., [4,31]). The carbonate content within mudstones that can be fossil-bearing (Figure 5j) decreases downhole. Contacts to siltstone are transitional, whereas contacts to basaltic flows and sills are often peperitic (Figure 6c), indicating that mudstone was unconsolidated when mafic volcanic rocks were emplaced. The mudstone marks a deeper pelagic and euxinic submarine environment that is similar to the "contact mudstone" described from Eskay Creek and is one of the highest stratigraphic levels within the Iskut River Formation $[4,5,41]$. However, prominent, pervasive mineralization or alteration is absent in the mudstones at the A6 Anomaly. 


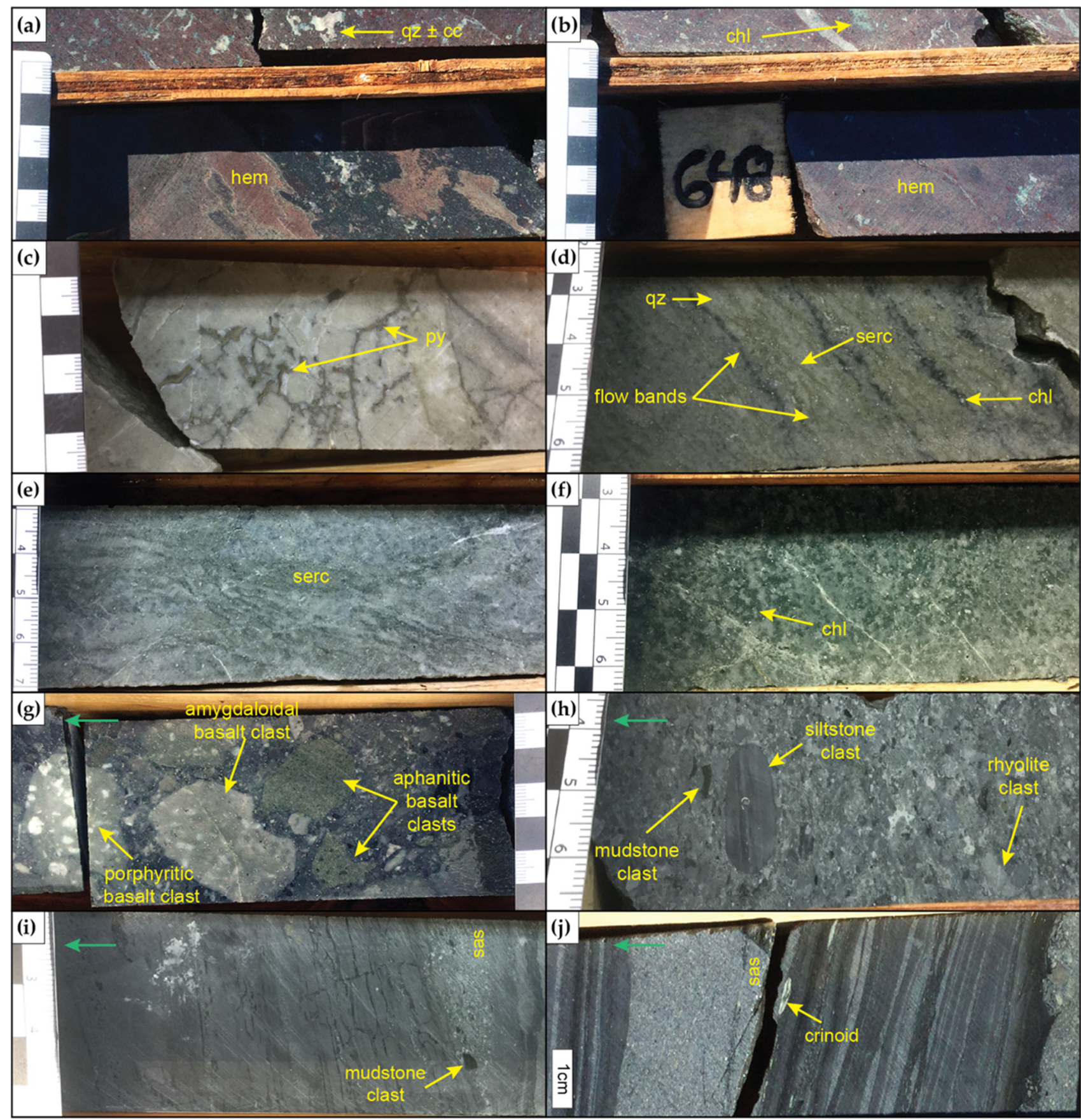

Figure 5. Igneous and epiclastic lithologies at the A6 Anomaly-Part I, (a,b) Hematite \pm chlorite altered basaltic tuffs to lapilli tuffs, partly with quartz \pm calcite filled amygdules occurring below altered felsic flows (BR-65), (c-f) Quartz-sericite \pm chlorite \pm pyrite altered felsic flows occurring beneath the retreating glacier, (c) silicified felsic flow with pyrite (BR-79), (d) Quartz-sericite-chlorite altered felsic flow with flow bands of chlorite and sericite (BR-82), (e) Quartz-sericite altered massive felsic flow (BR-82), (f) Quartz-sericite-chlorite altered massive felsic flow (BR-82), (g) Polymictic, poorly sorted cobble conglomerate with subround amygdaloidal, porphyritic, and aphanitic clasts in mudstone matrix conglomerate are not graded; green arrow depicts stratigraphic (BR-35), $(\mathbf{h}-\mathbf{j})$ epiclastic sequence ranging from conglomerate to siltstone, (h) Polymictic, poorly sorted pebble conglomerate with relatively well rounded clasts (siltstone, mudstone, rhyolite), conglomerate is not graded; green arrow depicts stratigraphic up (BR-87), (i) Finely bedded siltstone (grey variations) with medium- to coarse-grained sandstone bed containing polymictic epiclastic, subangular clasts including mudstone, sandstone bed is not graded; green arrow depicts stratigraphic up (BR-87), (j) Fine- to medium-grained, non-bedded sandstone alternating with thin carbonaceous and fossil-bearing siltstone to mudstone beds; green arrow depicts stratigraphic up (BR-65). Abbreviations: cc—calcite, chl—chlorite, hem—hematite, py—pyrite, qz—quartz, sas—sandstone, serc—sericite. 


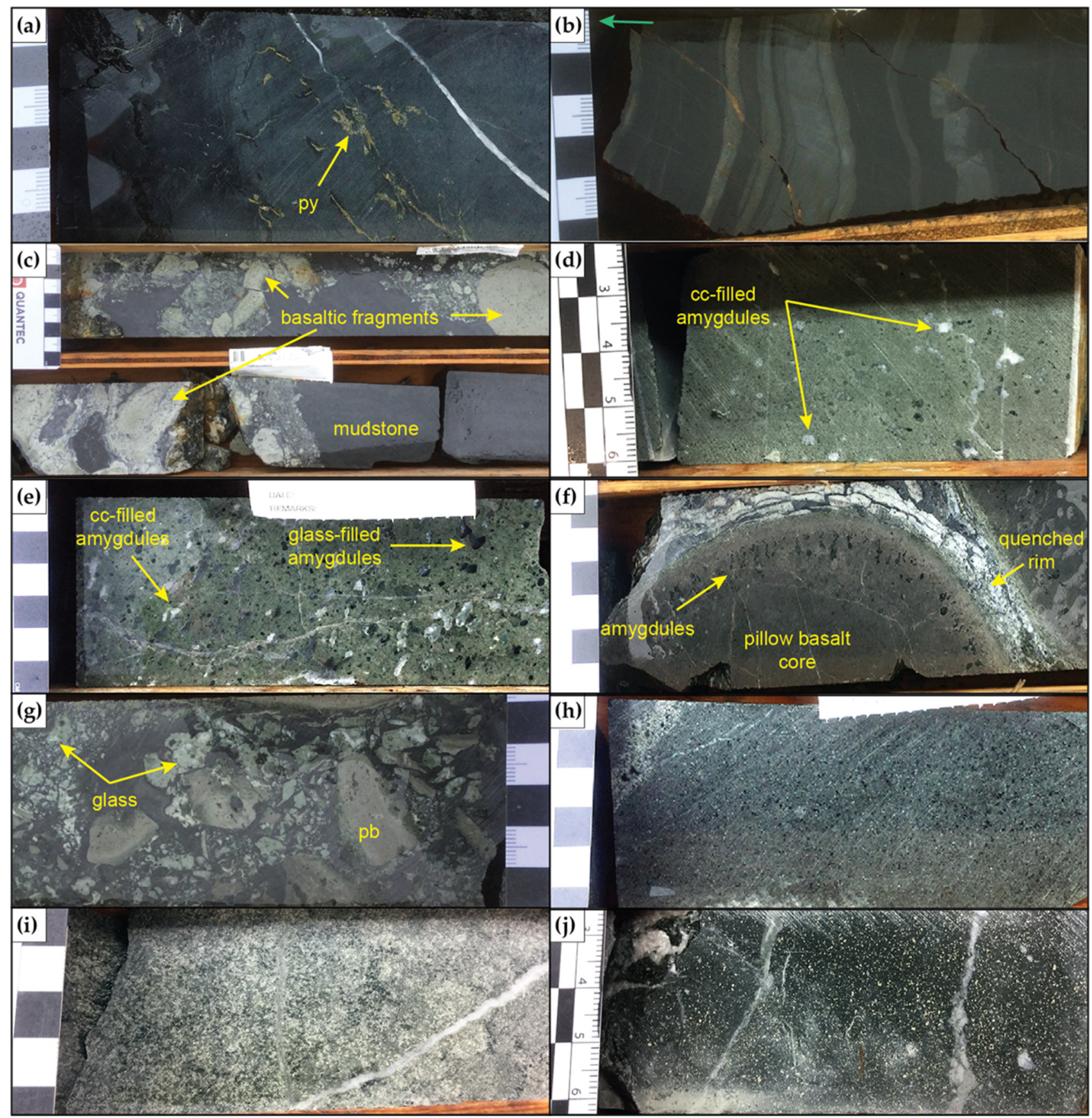

Figure 6. Igneous and epiclastic lithologies at the A6 Anomaly-Part II, (a,b) Mudstone, (a) Massive mudstone with disseminated pyrite and fine pyrite stringer crosscut by carbonate veinlets (BR-35), (b) Banded mudstone (dark) with finely bedded siltstone beds (grey); green arrow depicts stratigraphic up (BR-35), (c) Peperite, emplacement of aphanitic basalt into mudstone (BR-38), (d) Amygdaloidal basaltic flow (Group B basalt) with glass and calcite-filled vesicles (BR-82), (e) Amygdaloidal basaltic flow (Group A basalt) with glass and calcite-filled vesicles (BR-35), (f) Pillow basalt (Group A basalt) with amygdules along margins and quenched rim (BR-35), (g) Hyaloclastite with angular basaltic glass fragments in aphanitic grey matrix (BR-35), (h) Moderately phaneritic dolerite dyke (dyke I-a, BR-35), (i) Fine phaneritic dolerite dyke with cumulus texture (dyke I-b, BR-84), (j) Very fine-grained dolerite dyke (dyke II, BR-82). Abbreviations: cc-calcite, $\mathrm{pb}$-pillow basalt, py-pyrite. 
Massive, green volcanic rocks alternate with massive mudstones in the hanging wall of altered felsic flows and volcaniclastic rocks and on the east and west flank of the retreating glacier (Figure 4). The volcanic rocks vary in texture including: (1) amygdaloidal texture with $\mathrm{mm}$ - to $\mathrm{cm}$-sized, carbonate and/or glass-filled, round to elliptical vesicles (Figure 6d,e); (2) pillow basalts with amygdules near the quenched rim and (carbonaceous) mudstone interfills (Figure 6f); (3) porphyritic texture with up to $1 \mathrm{~cm}$ large plagioclase phenocrysts; and (4) massive, aphanitic basalts with no visible texture. Pillow basalts are common up stratigraphy, whereas amygdaloidal, porphyritic, and aphanitic basalts interpreted as flows and sills dominate lower in the stratigraphy. Pillow basalts and, to a lesser extent, massive basalt are accompanied by volcaniclastic rocks of similar composition.

Hyaloclastite, hyaloclastic breccia and flow top breccia, commonly $<10 \mathrm{~m}$ in thickness, alternate with pillow basalts (Figure $6 \mathrm{~g}$ ), indicating dynamic subaqueous eruption. Glass fragments in hyaloclastites are angular, up to several $\mathrm{cm}$ large, and occur in a grey, glassy matrix (Figure 6g).

Green, mafic dykes crosscut the stratigraphy (Figures 4 and $6 \mathrm{~h}-\mathrm{j}$ ). They range in thickness (up to $80 \mathrm{~m}$ ). There are dolerite types I (I-a and I-b) and II. Dolerite dyke type I are fine to moderately phaneritic (Figure $6 \mathrm{~h}$ ) and can have a cumulus appearance (Figure 6i) and minor chlorite alteration (Figure $6 \mathrm{~h}, \mathrm{i})$. Dolerite dyke II ( $<15 \mathrm{~m}$ thick) is fine-grained, has mm-sized, altered feldspar crystals (Figure 6j), and occurs exclusively beneath the retreating glacier (Figure 4). Dykes are related to volcanic activity during the Tertiary that affected the region [28].

\section{Materials and Methods}

Whole rock lithogeochemistry was carried out on all igneous units. Standard optical microscopy and scanned electron microscopy (SEM), X-ray diffraction (XRD), electron microprobe analysis (EMPA), and secondary ion mass spectrometry (SIMS) were carried out on altered felsic units. Sample information is provided in Supplementary Materials Table S1b,c.

\subsection{Whole Rock Lithogeochemistry}

Forty-three felsic, 8 intermediate, and 85 mafic igneous samples from the A6 Anomaly, as well as three samples from the Eskay Creek deposit ( 2 rhyolites, 1 basalt), were analyzed by ALS Geochemistry, North Vancouver, Canada for their major, minor, and trace element content. Major and minor elements $\left(\mathrm{SiO}_{2}, \mathrm{TiO}_{2}, \mathrm{Al}_{2} \mathrm{O}_{3}, \mathrm{MnO}, \mathrm{MgO}, \mathrm{Fe}_{2} \mathrm{O}_{3}, \mathrm{CaO}, \mathrm{Na}_{2} \mathrm{O}\right.$, $\mathrm{K}_{2} \mathrm{O}, \mathrm{P}_{2} \mathrm{O}_{5}$ ) were analyzed by $\mathrm{X}$-ray fluorescence following acid digestion and full fusion. Loss on ignition (LOI) was determined via furnace. Total $C$ and $S$ was analyzed via total combustion. Trace elements were analyzed using (1) four acid digestion with inductively coupled mass spectrometry (ICP-MS; Ag, $\mathrm{Cu}, \mathrm{Zn}, \mathrm{Pb}$ ), (2) Li borate fusion prior to acid dissolution with ICP-MS finish (Ba, Cr, Cs, Ga, Hf, Nb, Rb, Sn, Sr, Ta, Th, U, V, W, Y, Zr; and REE: La, Ce, Pr, Nd, Sm, Eu, Gd, Tb, Dy, Ho, Er, Tm, Yb, Lu), (3) aqua regia with ICP-MS finish (As, Bi, Hg, In, Re, Sb, Sc, Se, Te, Tl) and (4) fire assay with gravimetric finish $(\mathrm{Au})$. Several reference materials (RMs) were used to monitor precision and accuracy. For major and minor elements, precision and accuracy were excellent to very good $(\leq 5 \%)$. For trace elements, precision and accuracy ranged from excellent $(\leq 3 \%)$ to very good $(\leq 7 \%)$ and to good (7-10\%) for a few elements. Details are provided in Supplementary Materials Table S2a-c.

\subsection{SEM}

Transmitted light microscopy and SEM were used to define the mineralogy and texture of the altered felsic volcanic rocks. Elemental maps were obtained using a FEI Quanta 650 FEG SEM at the Manitoba Institute for Materials, University of Manitoba (UofM) between August and October 2020. The SEM was equipped with an Octane Super energy dispersive X-ray detector, and concentric backscattered electron detection was used in high vacuum mode at a pressure of $10^{-7} \mathrm{~Pa}$, a voltage of $15 \mathrm{kV}$, a working distance of 
approximately $10 \mathrm{~mm}$, and an aperture of $30 \mu \mathrm{m}$. Elemental maps of selected phases were obtained using $\mathrm{K}$ emission lines to detect $\mathrm{C}, \mathrm{O}, \mathrm{F}, \mathrm{P}, \mathrm{Na}, \mathrm{Mg}$, Al, Si, S, K, Ca, Cl, Ti, Fe, and $\mathrm{L}$ emission lines to detect $\mathrm{Zr}$ and Ba. Maps were performed at 64 counts for approximately 15 min per map. In order to detect possible interferences (e.g., $\mathrm{Zr} \mathrm{L}_{\alpha}$ interfering with $\mathrm{P} \mathrm{K}_{\alpha}$ ), the mineral of interest was scanned, and alternative emission lines were then used to check for any elemental overlaps. If an overlap occurred, the alternate, interference-free emission line was used for semiquantitative energy dispersive X-ray (EDX) scans. These scans allow for the detection of individual elements within minerals, but the elemental maps produced via EDX do not provide specific elemental concentrations; instead, they are based on raw counts per second. However, as the measured intensity for each element is proportional to its concentration, this approach is semiquantitative.

\subsection{XRD}

Twelve altered volcanic samples were analyzed by XRD by SGS Minerals, Lakefield, Ontario, Canada, in December of 2020 after samples had been pulverized to $\leq 2 \mu \mathrm{m}$. Powdered samples were analyzed using a Bruker AXS D8 Advance Diffractometer without further treatment. A Co radiation tube was used at $35 \mathrm{kV}$ and $40 \mathrm{~mA}$. The X-ray diffractograms were acquired at 3 to $70^{\circ} 2 \theta$ at step conditions of $0.02^{\circ}$ and $0.2 \mathrm{~s}$ per step. The detection limit ranges from 0.5 to $2.0 \%$ and is strongly dependent on crystallinity with major elements having lowest detection limits. Mineral identification and interpretation were performed by matching data from the sample material to single phase reference material. The reference patterns were assembled by the Joint Committee on Powder Diffraction Standards-International Centre for Diffraction Data and released on software as a database of Powder Diffraction Files (PDF). Semiquantitative analysis using the reference intensity ratio method was performed by analyzing the minerals peak height and their respective $\mathrm{I} / \mathrm{I}_{\text {cor }}$ values using corundum as internal standard; the $\mathrm{I} / \mathrm{I}_{\text {cor }}$ values were accessed through the PDF database to determine mineral composition. The mineral abundance of each sample was generated using Bruker-EVA software and the data were reconciled with the whole rock lithogeochemistry analyzed by ALS Geochemistry, North Vancouver, Canada.

\subsection{EMPA}

Sericite, K-feldspar and pyrite were analyzed on eight samples by a Cameca SX100 electron microprobe with five wavelength dispersive detectors at the Department of Geological Sciences, UofM in December 2020 and February 2021. The EMPA is equipped with a W filament, Be window, and Faraday cup. Total analyses time per element was $40 \mathrm{~s}$ with $20 \mathrm{~s}$ on peak time and $20 \mathrm{~s}$ on background. Raw analyses were recalculated to $\mathrm{wt} \%$ of elements and oxides using a standardized PAP correction [46]. Unknown and standard intensities were corrected for dead time.

Sericite and K-feldspar were analyzed for $\mathrm{Si}, \mathrm{Al}, \mathrm{Fe}, \mathrm{Mg}, \mathrm{Ca}, \mathrm{Na}, \mathrm{K}, \mathrm{Cr}, \mathrm{S}$, and $\mathrm{Cu}$; $\mathrm{Mn}$, $\mathrm{Ti}$, and $\mathrm{F}$ were scanned via energy-dispersive $\mathrm{X}$-ray spectroscopy and not detected in both phases and hence not analyzed. Calibration involved the following RMs (first-order element lines, crystals used, and detection limit in wt $\%$ based on 283 analyses): $\mathrm{Si}-$ diopside

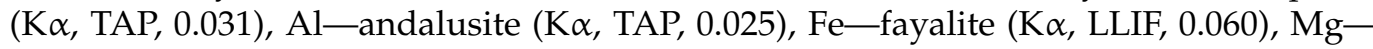
olivine $(\mathrm{K} \alpha, \mathrm{TAP}, 0.023)$, $\mathrm{Ca}$-diopside $(\mathrm{K} \alpha$, LPET, 0.026), Na—albite $(\mathrm{K} \alpha$, LTAP, 0.211), $\mathrm{K}$-orthoclase $\left(\mathrm{K} \alpha\right.$, LPET, 0.031), $\mathrm{Cr}$-chromite $(\mathrm{K} \alpha, \mathrm{LLIF}, 0.051), \mathrm{S}-\mathrm{CaSO}_{4}(\mathrm{~K} \alpha, \mathrm{LPET}$, $0.028)$, and $\mathrm{Cu}$-cuprite (K $\alpha, \mathrm{LLIF}, 0.098)$. Measurements were taken at $15 \mathrm{kV}$ with a $10 \mathrm{nA}$ current and a beam diameter of $5 \mu \mathrm{m}$ Despite careful examination of sericite, totals $<90 \mathrm{wt} \%$ occurred due to orientation and grain size; however, these analyses were deemed invalid since their stoichiometry was ambiguous. Total $\mathrm{H}_{2} \mathrm{O}$ concentration was calculated by subtracting analyzed totals in $\mathrm{wt} \%$ from $100 \mathrm{wt} \%$. K-feldspar data with totals of $100 \pm 2 \mathrm{wt} \%$ and stoichiometry representing orthoclase composition were deemed acceptable.

Pyrite was analyzed for $\mathrm{S}, \mathrm{Fe}, \mathrm{Cu}, \mathrm{Zn}, \mathrm{Pb}, \mathrm{As}, \mathrm{Sb}, \mathrm{Au}, \mathrm{Ag}, \mathrm{Ni}, \mathrm{Co}, \mathrm{Cr}$, and $\mathrm{Cd}$ at $20 \mathrm{~V}$, with a $20 \mathrm{nA}$ current, and a beam diameter of $1 \mu \mathrm{m}$. Calibration involved the following RMs (first-order element lines, crystals used, and detection limit in wt $\%$ based 
on 88 analyses): S—pyrite (K $\alpha, \mathrm{PET}, 0.051), \mathrm{Fe}$ - pyrite (K $\alpha, \mathrm{LLIF}, 0.044), \mathrm{Cu}$-chalcopyrite $(\mathrm{K} \alpha, \mathrm{LLIF}, 0.044), \mathrm{Zn}$-sphalerite (K $\alpha, \mathrm{LLIF}, 0.051), \mathrm{Pb}$-altaite (K $\alpha, \mathrm{PET}, 0.527)$, Asalloclasite (L $\alpha, \mathrm{PET}, 0.070), \mathrm{Sb}$-stibnite (L $\alpha, \mathrm{LPET}, 0.051), \mathrm{Au}$-electrum (M $\alpha, \mathrm{LPET}$, 0.124), Ag-electrum (L $\alpha, \mathrm{LPET}, 0.047), \mathrm{Ni}$-pentlandite $(\mathrm{K} \alpha, \mathrm{LLIF}, 0.036), \mathrm{Co}$ - cobalt $(\mathrm{K} \alpha$, LLIF, 0.042), $\mathrm{Cr}$-chromium (K $\alpha$, LPET, 0.015), and Cd-cadmoselite (L $\alpha$, LPET, 0.060). Analyses were deemed valid when totals of $100 \pm 2 \mathrm{wt} \%$ were achieved and stoichiometry represented pyrite.

\subsection{SIMS}

Secondary ion mass spectrometry on three samples was analyzed using a Cameca $7 \mathrm{f}$ with an ETP 133H electron multiplier detector at the Manitoba Isotope Research Facility, Department of Geological Sciences, UofM in February and May 2021 to determine the $\delta^{18} \mathrm{O}$ composition relative to Vienna Standard Mean Ocean Water (VSMOW) in sericite $(n=24)$ and quartz $(n=21)$. Prior to analysis, thin sections were prepared by cutting 1 inch diameter circles out of areas of interest. Prior to SIMS analysis, the thin section cuts were cleaned in an ultrasonic cleaner, first using tap water, followed by distilled water, and finally ethanol. The mounts were sputter coated with $\mathrm{a} \approx 400 \AA$ layer of gold to provide $\mathrm{a}$ conductive surface.

The analytical procedure is similar to the method detailed in Riciputi et al. [47]. Oxygen isotope analyses used $\mathrm{a} \approx 2 \mathrm{n} \AA$ and $\approx 5 \mathrm{n} \AA$ primary $\mathrm{Cs}^{+}$ion beam for illite and quartz, respectively, accelerated at $10 \mathrm{kV}$ and a spot size of $\approx 15 \mu \mathrm{m}$ for both phases. Contamination in the polished surface was prevented by pre-sputtering each spot for $45 \mathrm{~s}$. An electron gun was used to compensate for negative charged ions during analyses. The largest available contrast and field apertures (400 $\mu \mathrm{m}$ and $1800 \mu \mathrm{m}$ respectively), in conjunction with $150 \mu \mathrm{m}$ image field and an energy bandpass of $\pm 25 \mathrm{eV}$, were used to maximize sensitivity. The sample accelerating voltage was $-8.7 \mathrm{kV}$, with the electrostatic analyzer in the secondary column set to accept $-10 \mathrm{kV}$. This $300 \mathrm{~V}$ sample offset suppressed isobaric interferences [47]. Entrance slits were set to $225 \mu \mathrm{m}$ and a mass resolving power of 350 was used (measured at $10 \%$ valley), producing flat-top peaks. Two isotopes of oxygen, ${ }^{16} \mathrm{O}$ and ${ }^{18} \mathrm{O}$ with counts of $\approx 1.5 \times 10^{6}$ and $\approx 3 \times 10^{3}$, respectively, were detected by alternating the magnetic field between masses. A typical analysis comprised 80 cycles and lasted $\approx 13 \mathrm{~min}$.

All isotope measurements are reported in delta $(\delta)$ notation as parts per thousand variations relative to a reference material and expressed in per mil (\%o). Mathematically, the $\mathrm{O}$ isotopic composition of any substance is expressed as (Equation (1)):

$$
\delta^{18} \mathrm{O}=\left[\frac{\left({ }^{16} \mathrm{O} /{ }^{18} \mathrm{O}\right)_{\text {Sample }}-\left({ }^{16} \mathrm{O} /{ }^{18} \mathrm{O}\right)_{\text {Reference }}}{\left({ }^{16} \mathrm{O} /{ }^{18} \mathrm{O}\right)_{\text {Reference }}}\right] \times 1000,
$$

with $\left({ }^{16} \mathrm{O} /{ }^{18} \mathrm{O}\right)_{\text {Sample }}$ is the measured ${ }^{16} \mathrm{O} /{ }^{18} \mathrm{O}$ ratio of the sample and ${ }^{16} \mathrm{O} /{ }^{18} \mathrm{O}$ Reference is the known ${ }^{16} \mathrm{O} /{ }^{18} \mathrm{O}$ ratio of the reference material [48]. For $\mathrm{O}$ isotopic composition the agreed upon reference is VSMOW with a $\delta^{18} \mathrm{O}=0 \%$ by definition [49-51].

The Fractionation Factor (FF or $\alpha_{\text {SIMS }}$ ) was calculated for each analysis (Equation (2)). Our procedure is similar to [47]:

$$
\mathrm{FF}\left(\alpha_{\text {SIMS }}\right)=\frac{R_{\text {SIMS }}}{R_{\text {True }}}
$$

where $\mathrm{R}_{\text {SIMS }}$ is the isotopic ratio measured by SIMS and $\mathrm{R}_{\text {True }}$ is the bulk value of the RM used, which is $2.0261 \times 10^{-3}$ for the in-house muscovite RM. Instrument mass fractionation (IMF) was quantified using Equation (3):

$$
\operatorname{IMF}(\%)=1000\left(\alpha_{\text {SIMS }}-1\right)
$$


where $\alpha_{\text {SIMS }}$ is the fractionation factor from Equation (2). The spot-to-spot reproducibility was calculated for each grain analyzed. This is defined as (Equation (4)):

$$
\text { Reproducibility }=\sqrt{\frac{\sum\left(\mathrm{IMF}-\mathrm{IMF}_{\mathrm{avg}}\right)^{2}}{(\mathrm{n}-1)}},
$$

where IMF is the measured instrumental mass fractionation for each spot, $\mathrm{IMF}_{\text {avg }}$ is the average IMF for all analyses, and $\mathrm{n}$ is the total number of analyses. The within-spot reproducibility for oxygen was $0.8 \%$ o $(1 \sigma)$ and $0.6 \%(1 \sigma)$ for the in-house muscovite and the UWQ-1 quartz RMs, respectively. The used in-house muscovite RM has a $\delta^{18} \mathrm{O}$ value of $10.4 \%$, whereas UWQ-1 has a O isotope composition of $12.3 \%$ [52]. Results for both RMs are compiled in Supplementary Materials Table S3.

\section{Results}

\subsection{Whole Rock Lithogeochemistry}

The results of whole rock lithogeochemistry for the 136 igneous and volcaniclastic rocks from the A6 Anomaly are shown in Figures 7-12, Table 2 and Supplementary Materials Table S4.

The weakly to moderately altered felsic flows and subordinate volcaniclastic rocks have a calc-alkaline affinity $(\mathrm{Zr} / \mathrm{Y}>4.5 ;$ [53]) and are rhyodacite to trachyte in composition (Figure $7 \mathrm{a}, \mathrm{b}$ ) with highest $\mathrm{SiO}_{2}$, lowest $\mathrm{TiO}_{2}$ and $\mathrm{Fe}_{2} \mathrm{O}_{3}(\mathrm{t})$, and intermediate $\mathrm{Al}_{2} \mathrm{O}_{3}$ composition of all analyzed igneous lithologies (Figure 8a-c, Table 2). Alkali earth $(\mathrm{CaO})$ and alkali $\left(\mathrm{Na}_{2} \mathrm{O}, \mathrm{K}_{2} \mathrm{O}\right)$ elements show a wider compositional range due to their mobility related to hydrothermal alteration (Figure $8 \mathrm{~d}, \mathrm{e}$ ). Loss on ignition is variable, $\mathrm{C}$ concentration is low, and the strong variation in $\mathrm{S}$ is related to varying degrees of sulfide mineralization. A strong correlation between $\mathrm{Al}_{2} \mathrm{O}_{3}$ and high field strengths elements (HFSE) $\mathrm{Zr}, \mathrm{Nb}, \mathrm{Y}$ and Ta suggest they were immobile during alteration (Figure $8 \mathrm{f}-\mathrm{i}$ ). Rare earth elements are slightly enriched in light REEs show a pronounced negative Eu anomaly and flat heavy REE pattern (relative to primitive mantle (Figure 9, Table 2). Metal content is generally low in the altered felsic units with no pronounced enrichment in $\mathrm{Au}, \mathrm{Ag}, \mathrm{Cu}, \mathrm{Zn}$, and $\mathrm{Pb}$.

Table 2. Summary of whole rock lithogeochemistry for selected elements and parameters of the igneous units at the A6 Anomaly. Abbreviations: Av \pm Stdev-average \pm standard deviation, $\mathrm{n}$-number of samples.

\begin{tabular}{|c|c|c|c|c|c|c|c|}
\hline & Felsic Units & $\begin{array}{c}\text { Group A } \\
\text { Basalts }\end{array}$ & $\begin{array}{c}\text { Group B } \\
\text { Basalts }\end{array}$ & $\begin{array}{c}\text { Group B } \\
\text { Andesites }\end{array}$ & Dyke I-a & Dyke I-b & Dyke II \\
\hline & Av \pm Stdev & $\mathbf{A v} \pm$ Stdev & $\mathbf{A v} \pm$ Stdev & $\mathbf{A v} \pm$ Stdev & Av \pm Stdev & $\mathbf{A v} \pm$ Stdev & $\mathbf{A v} \pm$ Stdev \\
\hline n & 43 & 38 & 38 & 8 & 3 & 3 & 3 \\
\hline $\mathrm{SiO}_{2}[\mathrm{wt} \%]$ & $69.9 \pm 3.93$ & $42.1 \pm 4.14$ & $49.2 \pm 4.43$ & $60.7 \pm 4.56$ & $40.9 \pm 3.04$ & $41.4 \pm 3.84$ & $39.0 \pm 4.98$ \\
\hline $\mathrm{TiO}_{2}$ & $0.21 \pm 0.03$ & $1.10 \pm 0.18$ & $1.23 \pm 0.34$ & $0.77 \pm 0.2$ & $0.77 \pm 0.16$ & $1.29 \pm 0.17$ & $1.87 \pm 0.08$ \\
\hline $\mathrm{Al}_{2} \mathrm{O}_{3}$ & $14.6 \pm 2.23$ & $16.3 \pm 1.59$ & $16.8 \pm 1.67$ & $17.6 \pm 1.99$ & $16.2 \pm 1.78$ & $16.4 \pm 0.93$ & $18.6 \pm 0.72$ \\
\hline $\mathrm{Fe}_{2} \mathrm{O}_{3}(\mathrm{t})$ & $2.30 \pm 1.45$ & $11.7 \pm 1.97$ & $8.64 \pm 1.67$ & $4.19 \pm 0.85$ & $12.0 \pm 0.48$ & $14.3 \pm 1.11$ & $14.0 \pm 1.94$ \\
\hline $\mathrm{MnO}$ & $0.05 \pm 0.03$ & $0.18 \pm 0.05$ & $0.18 \pm 0.08$ & $0.12 \pm 0.04$ & $0.21 \pm 0.01$ & $0.20 \pm 0.02$ & $0.29 \pm 0.09$ \\
\hline $\mathrm{MgO}$ & $0.71 \pm 0.37$ & $7.01 \pm 2.18$ & $3.80 \pm 1.39$ & $1.01 \pm 0.36$ & $13.3 \pm 4.03$ & $5.17 \pm 1.5$ & $5.20 \pm 2.51$ \\
\hline $\mathrm{CaO}$ & $1.86 \pm 1.07$ & $9.68 \pm 3.02$ & $7.18 \pm 3.72$ & $3.23 \pm 1.8$ & $9.61 \pm 0.51$ & $8.40 \pm 1.83$ & $7.01 \pm 4.86$ \\
\hline $\mathrm{Na}_{2} \mathrm{O}$ & $1.80 \pm 0.87$ & $2.60 \pm 1.43$ & $3.77 \pm 2.15$ & $7.06 \pm 1.4$ & $0.92 \pm 1.15$ & $3.04 \pm 1.74$ & $2.52 \pm 0.11$ \\
\hline $\mathrm{K}_{2} \mathrm{O}$ & $4.93 \pm 1.57$ & $0.62 \pm 0.83$ & $1.92 \pm 1.36$ & $1.54 \pm 1.39$ & $0.09 \pm 0.09$ & $0.63 \pm 1.04$ & $1.96 \pm 1.61$ \\
\hline $\mathrm{P}_{2} \mathrm{O}_{5}$ & $0.07 \pm 0.01$ & $0.15 \pm 0.07$ & $0.65 \pm 0.29$ & $0.42 \pm 0.12$ & $0.08 \pm 0.03$ & $0.10 \pm 0.01$ & $0.89 \pm 0.03$ \\
\hline LOI & $2.90 \pm 1.14$ & $7.74 \pm 3.47$ & $6.03 \pm 2.76$ & $2.97 \pm 1.54$ & $5.58 \pm 1.76$ & $7.94 \pm 3.36$ & $8.21 \pm 2.84$ \\
\hline Total & $100 \pm 1.66$ & $99.8 \pm 0.48$ & $100 \pm 1.7$ & $100 \pm 0.32$ & $100 \pm 0.19$ & $99.9 \pm 0.42$ & $101 \pm 0.13$ \\
\hline C & $0.41 \pm 0.24$ & $1.16 \pm 1.02$ & $0.94 \pm 0.94$ & $0.56 \pm 0.43$ & $0.06 \pm 0$ & $1.37 \pm 0.88$ & $1.27 \pm 1.09$ \\
\hline S & $0.47 \pm 1.16$ & $0.18 \pm 0.27$ & $0.37 \pm 1.02$ & $0.13 \pm 0.07$ & $0.08 \pm 0.04$ & $0.29 \pm 0.2$ & $0.29 \pm 0.21$ \\
\hline $\mathrm{Ni}[\mathrm{ppm}]$ & $2.34 \pm 1.43$ & $106 \pm 40$ & $32.0 \pm 24.2$ & $2.00 \pm 1.41$ & $325 \pm 159$ & $113 \pm 25.1$ & $46.7 \pm 10.3$ \\
\hline V & $28.0 \pm 9.94$ & $280 \pm 29.3$ & $176 \pm 61.5$ & $18.4 \pm 3.66$ & $222 \pm 51.1$ & $284 \pm 38.2$ & $351 \pm 41.9$ \\
\hline $\mathrm{Cu}$ & $9.25 \pm 24.3$ & $67.6 \pm 14.8$ & $28.3 \pm 23.5$ & $2.00 \pm 1.41$ & $62.3 \pm 47.7$ & $67.7 \pm 2.08$ & $45.3 \pm 37.9$ \\
\hline $\mathrm{Zn}$ & $41.9 \pm 37.5$ & $92.1 \pm 18.4$ & $92.9 \pm 30.1$ & $103 \pm 22.4$ & $109 \pm 14.4$ & $118 \pm 10.0$ & $251 \pm 108$ \\
\hline $\mathrm{Pb}$ & $13.6 \pm 12.0$ & $5.50 \pm 4.95$ & $5.80 \pm 8.05$ & $7.50 \pm 1.93$ & & & $5.50 \pm 0.71$ \\
\hline $\mathrm{Nb}$ & $12.0 \pm 2.26$ & $2.03 \pm 0.63$ & $9.59 \pm 2.73$ & $17.4 \pm 2.24$ & $1.27 \pm 0.42$ & $1.10 \pm 0.17$ & $20.2 \pm 1.98$ \\
\hline $\mathrm{Zr}$ & $147 \pm 19.5$ & $50.8 \pm 9.96$ & $125 \pm 27.6$ & $227 \pm 34.3$ & $43.0 \pm 10.1$ & $32.0 \pm 2.65$ & $115 \pm 9.54$ \\
\hline $\mathrm{Y}$ & $18.2 \pm 4.82$ & $21.5 \pm 2.48$ & $26.9 \pm 8.85$ & $38.8 \pm 4.99$ & $17.5 \pm 4.3$ & $18.9 \pm 2.37$ & $23.1 \pm 4.91$ \\
\hline
\end{tabular}


Table 2. Cont.

\begin{tabular}{|c|c|c|c|c|c|c|c|}
\hline & Felsic Units & $\begin{array}{c}\text { Group A } \\
\text { Basalts }\end{array}$ & $\begin{array}{l}\text { Group B } \\
\text { Basalts }\end{array}$ & $\begin{array}{c}\text { Group B } \\
\text { Andesites }\end{array}$ & Dyke I-a & Dyke I-b & Dyke II \\
\hline & Av \pm Stdev & Av \pm Stdev & Av \pm Stdev & Av \pm Stdev & Av \pm Stdev & Av \pm Stdev & Av \pm Stdev \\
\hline $\mathrm{Ta}$ & $0.97 \pm 0.27$ & $0.25 \pm 0.17$ & $0.58 \pm 0.28$ & $0.98 \pm 0.14$ & $0.13 \pm 0.06$ & $0.43 \pm 0.32$ & $1.10 \pm 0.36$ \\
\hline $\mathrm{La}$ & $29.7 \pm 7.35$ & $5.64 \pm 1.96$ & $21.8 \pm 6.14$ & $39.8 \pm 6.56$ & $3.77 \pm 1.65$ & $2.87 \pm 0.45$ & $39.1 \pm 1.5$ \\
\hline $\mathrm{Ce}$ & $53.6 \pm 12.7$ & $13.3 \pm 3.44$ & $47.1 \pm 14.1$ & $83.9 \pm 15.5$ & $8.37 \pm 2.25$ & $8.23 \pm 0.99$ & $79.1 \pm 3.36$ \\
\hline $\operatorname{Pr}$ & $5.87 \pm 1.38$ & $2.10 \pm 0.48$ & $6.30 \pm 2.11$ & $10.6 \pm 1.67$ & $1.32 \pm 0.35$ & $1.54 \pm 0.18$ & $9.25 \pm 0.48$ \\
\hline $\mathrm{Nd}$ & $21.0 \pm 4.72$ & $10.4 \pm 2.2$ & $27.7 \pm 9.19$ & $42.6 \pm 5.87$ & $6.73 \pm 2.03$ & $9.00 \pm 0.66$ & $37.3 \pm 1.85$ \\
\hline $\mathrm{Sm}$ & $3.95 \pm 0.79$ & $3.12 \pm 0.47$ & $6.19 \pm 2.17$ & $8.56 \pm 1.06$ & $2.12 \pm 0.41$ & $2.92 \pm 0.42$ & $7.43 \pm 0.57$ \\
\hline $\mathrm{Eu}$ & $0.70 \pm 0.19$ & $1.05 \pm 0.18$ & $1.81 \pm 0.6$ & $2.17 \pm 0.29$ & $0.81 \pm 0.42$ & $0.90 \pm 0.44$ & $1.96 \pm 0.29$ \\
\hline $\mathrm{Gd}$ & $3.28 \pm 0.76$ & $3.63 \pm 0.44$ & $6.06 \pm 2.22$ & $7.46 \pm 1.01$ & $2.59 \pm 0.73$ & $3.89 \pm 0.65$ & $6.21 \pm 0.87$ \\
\hline $\mathrm{Tb}$ & $0.48 \pm 0.13$ & $0.61 \pm 0.07$ & $0.84 \pm 0.29$ & $1.14 \pm 0.16$ & $0.47 \pm 0.09$ & $0.56 \pm 0.06$ & $0.79 \pm 0.12$ \\
\hline Dy & $3.04 \pm 0.89$ & $3.79 \pm 0.43$ & $5.12 \pm 1.82$ & $6.98 \pm 1.13$ & $2.94 \pm 0.89$ & $3.90 \pm 0.44$ & $4.28 \pm 0.84$ \\
\hline Ho & $0.64 \pm 0.17$ & $0.83 \pm 0.09$ & $1.04 \pm 0.34$ & $1.41 \pm 0.19$ & $0.68 \pm 0.15$ & $0.79 \pm 0.09$ & $0.85 \pm 0.16$ \\
\hline Er & $2.05 \pm 0.54$ & $2.46 \pm 0.26$ & $3.06 \pm 1.05$ & $4.38 \pm 0.48$ & $2.03 \pm 0.54$ & $2.23 \pm 0.31$ & $2.44 \pm 0.31$ \\
\hline $\mathrm{Tm}$ & $0.31 \pm 0.08$ & $0.35 \pm 0.04$ & $0.43 \pm 0.13$ & $0.64 \pm 0.06$ & $0.29 \pm 0.1$ & $0.30 \pm 0.03$ & $0.29 \pm 0.04$ \\
\hline $\mathrm{Yb}$ & $2.35 \pm 0.59$ & $2.33 \pm 0.23$ & $2.94 \pm 0.89$ & $4.30 \pm 0.49$ & $1.81 \pm 0.52$ & $2.20 \pm 0.23$ & $2.15 \pm 0.13$ \\
\hline $\mathrm{Lu}$ & $0.36 \pm 0.09$ & $0.35 \pm 0.04$ & $0.43 \pm 0.12$ & $0.66 \pm 0.08$ & $0.29 \pm 0.09$ & $0.31 \pm 0.04$ & $0.29 \pm 0.02$ \\
\hline$\Sigma \mathrm{REE}$ & $127 \pm 28.5$ & $50.0 \pm 9.32$ & $131 \pm 40.2$ & $215 \pm 31.7$ & $34.2 \pm 10.1$ & $39.7 \pm 3.68$ & $192 \pm 9.74$ \\
\hline $\mathrm{Zr} / \mathrm{Y}$ & $8.41 \pm 1.61$ & $2.38 \pm 0.46$ & $4.87 \pm 1.04$ & $5.90 \pm 0.88$ & $2.46 \pm 0.21$ & $1.70 \pm 0.08$ & $5.16 \pm 1.45$ \\
\hline $\mathrm{Zr} / \mathrm{Ti}$ & $0.12 \pm 0.01$ & $0.01 \pm 0$ & $0.02 \pm 0$ & $0.05 \pm 0.01$ & $0.01 \pm 0$ & $0.00 \pm 0$ & $0.01 \pm 0$ \\
\hline $\mathrm{Nb} / \mathrm{Yb}$ & $5.37 \pm 1.53$ & $0.88 \pm 0.27$ & $3.32 \pm 0.62$ & $4.05 \pm 0.43$ & $0.70 \pm 0.18$ & $0.50 \pm 0.03$ & $9.49 \pm 1.5$ \\
\hline $\mathrm{Mg \#}^{1}$ & $38.6 \pm 11.6$ & $53.3 \pm 9.57$ & $45.5 \pm 7.32$ & $31.8 \pm 6.65$ & $67.6 \pm 6.9$ & $41.3 \pm 7.9$ & $40.8 \pm 8.83$ \\
\hline $\mathrm{La} / \mathrm{Sm}$ & $7.52 \pm 1.01$ & $1.80 \pm 0.45$ & $3.64 \pm 0.61$ & $4.64 \pm 0.44$ & $1.73 \pm 0.42$ & $0.99 \pm 0.18$ & $5.27 \pm 0.22$ \\
\hline $\mathrm{Ce} / \mathrm{Ce}^{* 2}$ & $0.97 \pm 0.02$ & $0.93 \pm 0.06$ & $0.95 \pm 0.04$ & $0.98 \pm 0.04$ & $0.90 \pm 0.11$ & $0.94 \pm 0.02$ & $0.98 \pm 0.02$ \\
\hline $\mathrm{Eu} / \mathrm{Eu}^{* 3}$ & $0.59 \pm 0.08$ & $0.95 \pm 0.11$ & $0.93 \pm 0.19$ & $0.83 \pm 0.08$ & $1.01 \pm 0.27$ & $0.81 \pm 0.37$ & $0.89 \pm 0.15$ \\
\hline $\mathrm{Yb}_{\mathrm{n}} 4$ & $10.7 \pm 2.68$ & $10.6 \pm 1.07$ & $13.4 \pm 4.06$ & $19.5 \pm 2.24$ & $8.24 \pm 2.36$ & $10.0 \pm 1.06$ & $9.76 \pm 0.61$ \\
\hline$(\mathrm{La} / \mathrm{Yb})_{\mathrm{n}}{ }^{5}$ & $8.9 \pm 3.16$ & $1.62 \pm 0.52$ & $5.09 \pm 1.20$ & $6.26 \pm 1.21$ & $1.35 \pm 0.24$ & $0.87 \pm 0.15$ & $12.2 \pm 0.41$ \\
\hline$(\mathrm{La} / \mathrm{Sm})_{\mathrm{n}} 6$ & $4.73 \pm 0.63$ & $1.13 \pm 0.28$ & $2.29 \pm 0.38$ & $2.92 \pm 0.28$ & $1.09 \pm 0.27$ & $0.62 \pm 0.11$ & $3.32 \pm 0.14$ \\
\hline$(\mathrm{Gd} / \mathrm{Yb})_{\mathrm{n}} 7$ & $1.16 \pm 0.27$ & $1.26 \pm 0.11$ & $1.65 \pm 0.25$ & $1.40 \pm 0.09$ & $1.15 \pm 0.02$ & $1.42 \pm 0.11$ & $2.33 \pm 0.24$ \\
\hline
\end{tabular}

${ }^{1} \mathrm{Mg} \#=$ molar $\left(100 \times(\mathrm{Mg} /(\mathrm{Mg}+\mathrm{Fe}))[54] .{ }^{2} \mathrm{Ce} / \mathrm{Ce}^{*}=(\mathrm{Ce} / 0.808) /\left(\operatorname{sqrt}\left((\mathrm{La} / 0.31)^{2 / 3} \times(\mathrm{Nd} / 0.6)^{1 / 3}\right)\right)\right)[55] .{ }^{3} \mathrm{Eu} / \mathrm{Eu}^{*}=$ $(\mathrm{Eu} / 0.0735) /(\operatorname{sqrt}((\mathrm{Sm} / 0.195) \times(\mathrm{Gd} / 0.295)))[55] .{ }^{4} \mathrm{Yb}_{\mathrm{n}}=\mathrm{Yb} / 0.22[56] .{ }^{5} \operatorname{REE}$ fractionation: $(\mathrm{La} / \mathrm{Yb})_{\mathrm{n}}=(\mathrm{La} / 0.329) /(\mathrm{Yb} / 0.22)[13,56]$. ${ }^{6}$ LREE fractionation: $(\mathrm{La} / \mathrm{Sm})_{\mathrm{n}}=(\mathrm{La} / 0.31) /(\mathrm{Sm} / 0.195)[55] .{ }^{7}$ HREE fractionation: $(\mathrm{Gd} / \mathrm{Yb})_{\mathrm{n}}=(\mathrm{Gd} / 0.259) /(\mathrm{Yb} / 0.209)[55]$.

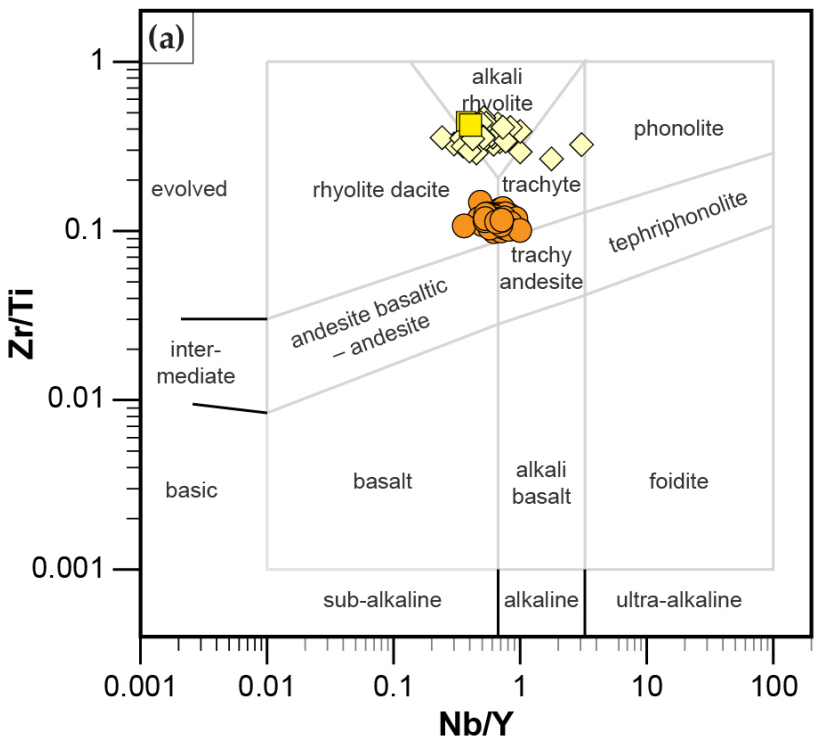

A6 Anomaly felsic units

Felsic flows and volcaniclastic rocks (altered)

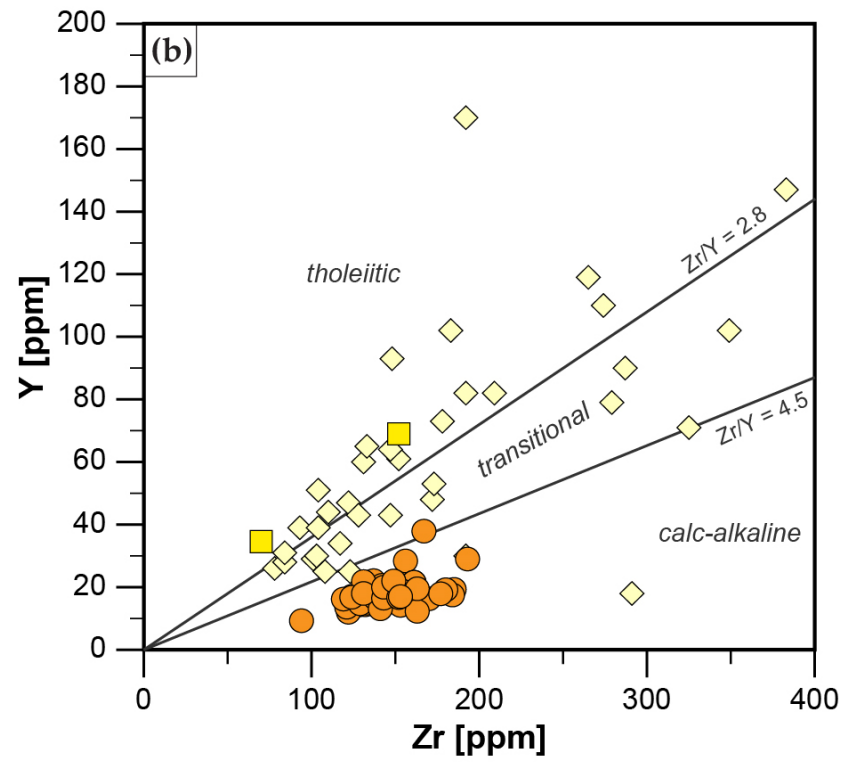

Eskay Creek rhyolite

$\square$ This study

$\diamond[40]$

Figure 7. Rock classification and magmatic affinity of altered felsic igneous lithologies at the A6 Anomaly in comparison to samples from Eskay Creek (this study and [40]). (a) Nb/Y vs. Zr/Ti rock classification diagram after [57], (b) Zr vs. Y magmatic affinity plot for alkaline rocks using $\mathrm{Zr} / \mathrm{Y}$ ratios of [53]. 

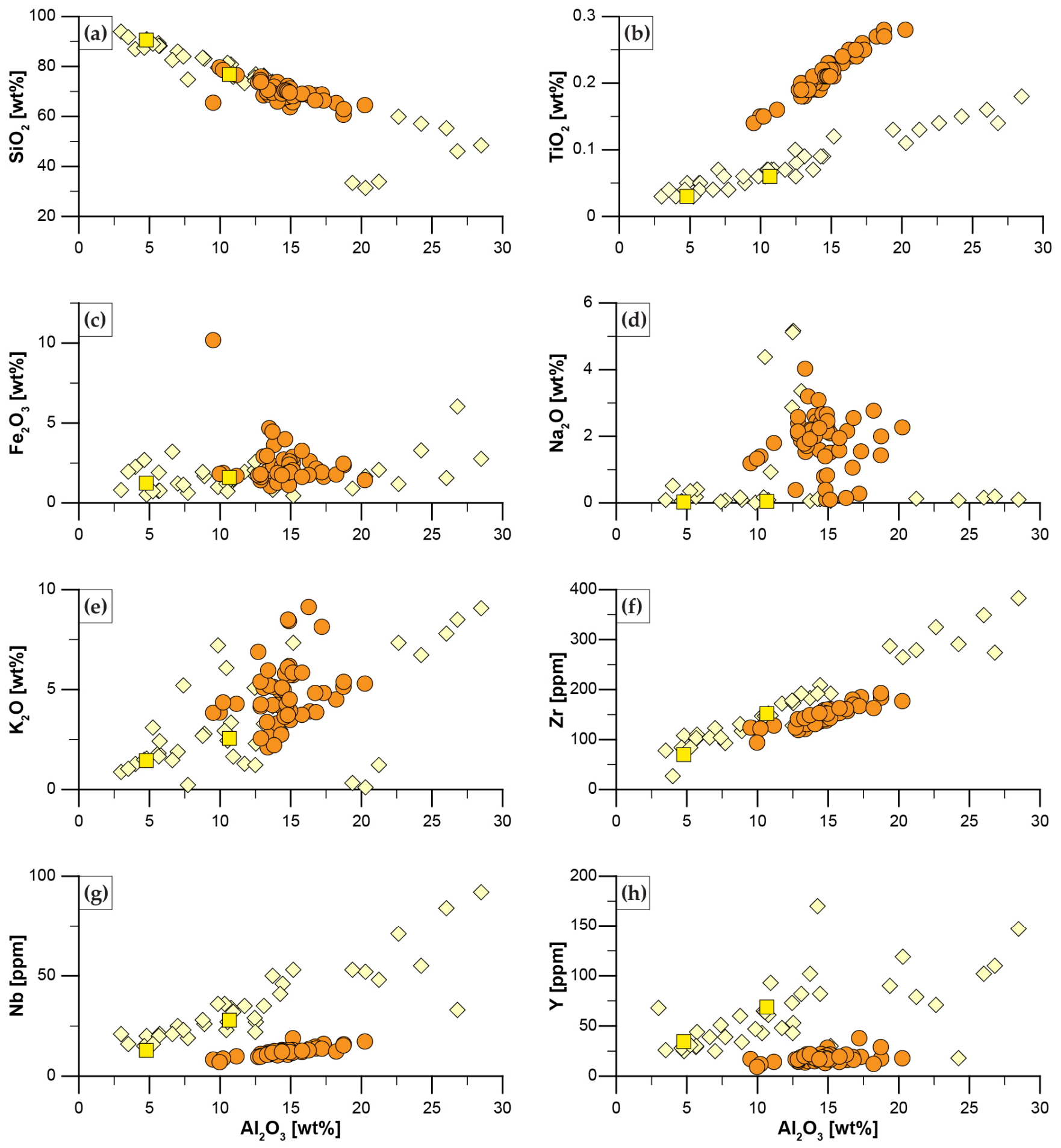

\section{A6 Anomaly felsic units}

Felsic flows and volcaniclastic rocks (altered)

\section{Eskay Creek rhyolite \\ This study \\ $\diamond[40]$}

Figure 8. Bivariate plots of felsic flows and volcaniclastic lithologies from the A6 Anomaly and Eskay Creek (with data from [40] and this study) for selected major, minor and trace elements versus $\mathrm{Al}_{2} \mathrm{O}_{3}[\mathrm{wt} \%]$. (a) $\mathrm{SiO}_{2}$ [wt $\%$ ], (b) $\mathrm{TiO}_{2}$ [wt $\%$, (c) $\mathrm{Fe}_{2} \mathrm{O}_{3}[\mathrm{wt} \%]$, (d) $\mathrm{CaO}$ [wt\%], (e) $\mathrm{K}_{2} \mathrm{O}$ [wt\%], (f) $\mathrm{Zr}$ [ppm], (g) $\mathrm{Nb}$ [ppm], (h) $\mathrm{Y}$ [ppm]. 


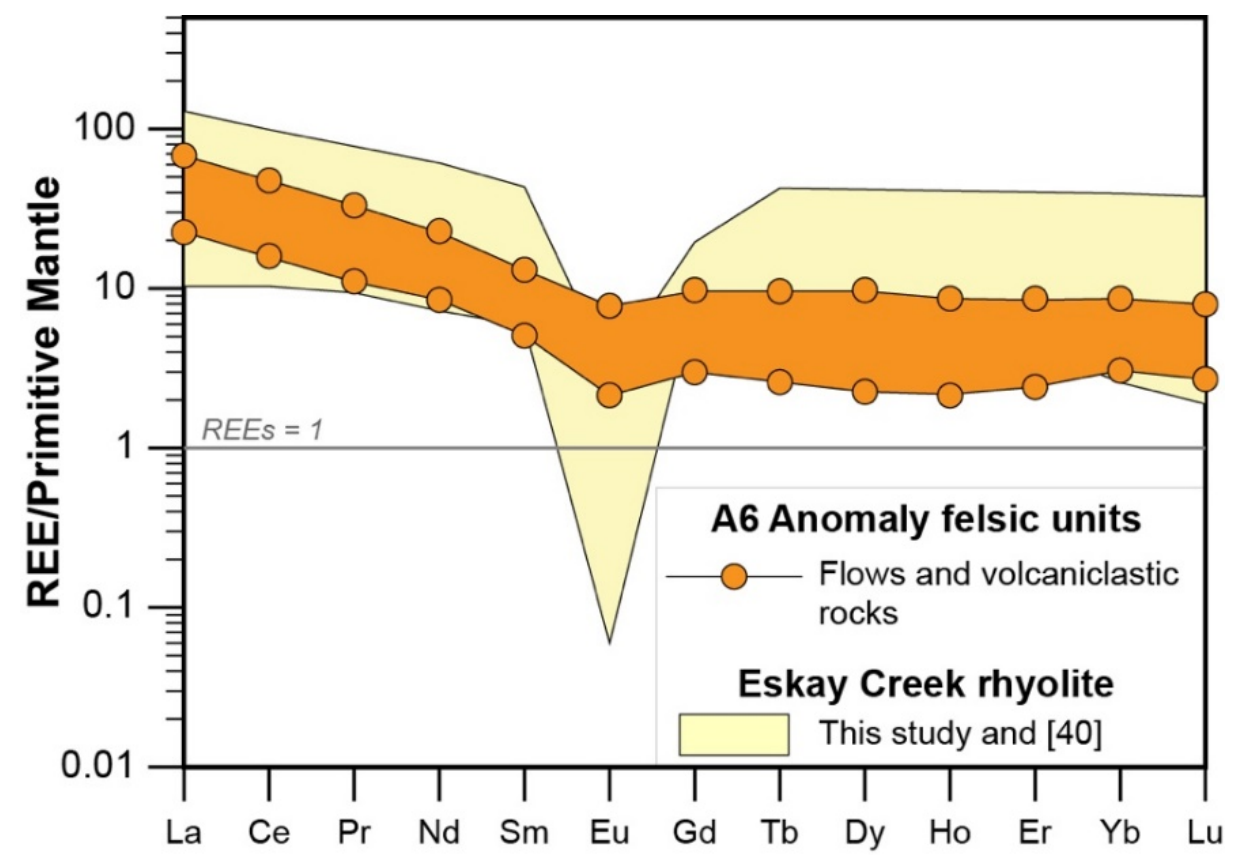

Figure 9. Spider diagram of REEs normalized to primitive mantle [58] for felsic units at the A6 Anomaly (orange) and Eskay Creek rhyolite (light yellow, [40] and this study).
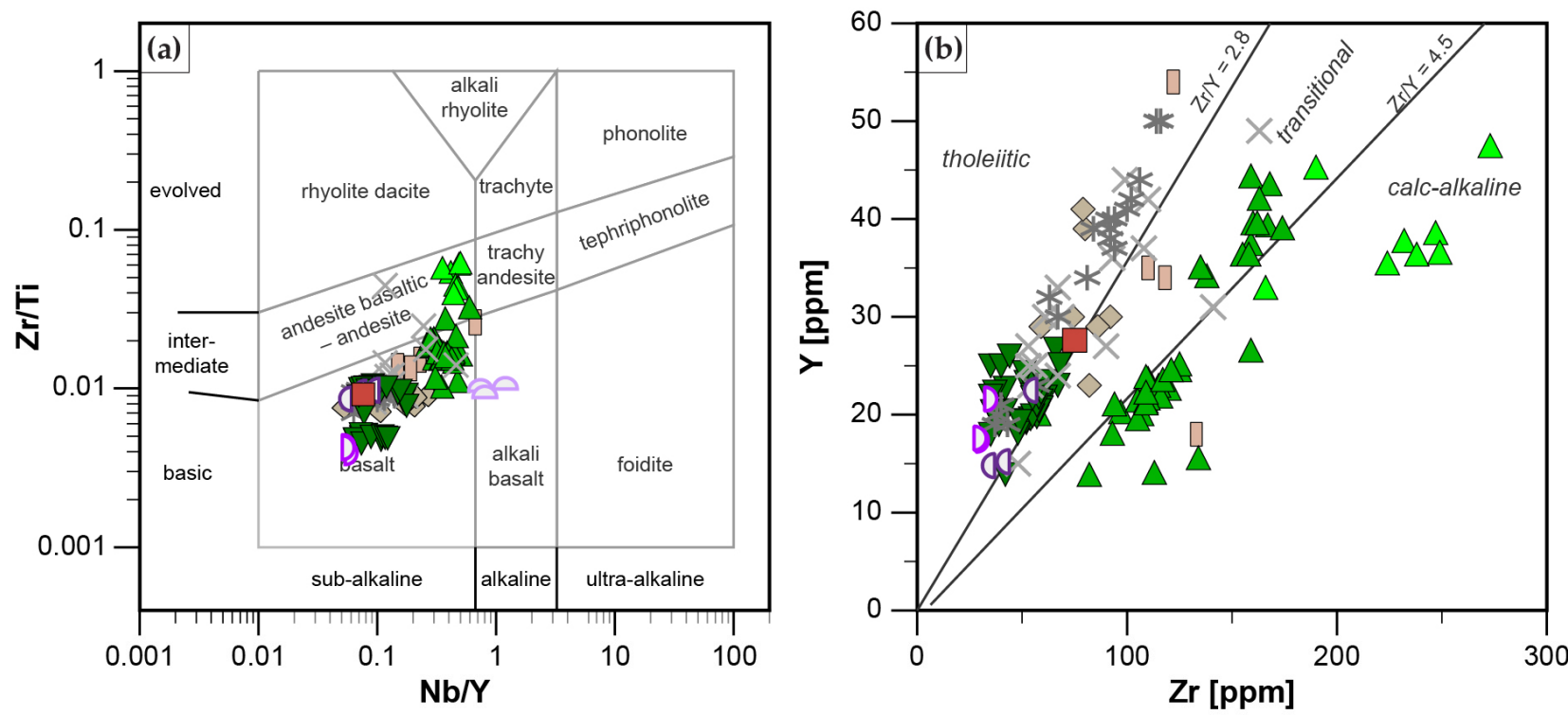

\begin{tabular}{|cc}
\hline A6 Anomaly mafic and intermediate units \\
Flows and volcaniclastic rocks & Dykes \\
$\nabla$ Group A basalts & 0 Dyke I-a \\
$\triangle$ Group B basalts & $D$ Dyke I-b \\
$\triangle$ Group B andesites & $\triangle$ Dyke II
\end{tabular}
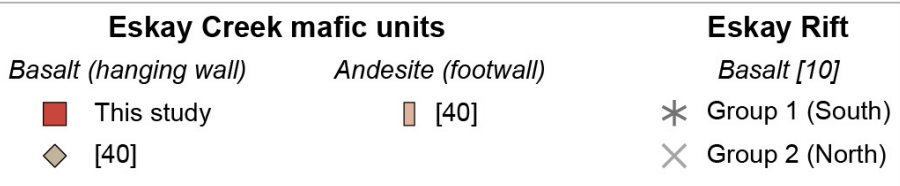

Figure 10. Rock classification and their magmatic affinity of mafic and intermediate igneous lithologies at the A6 Anomaly in comparison to samples from Eskay Creek (with data from [40] and this study) and basalts from the Eskay rift [10]. (a) $\mathrm{Nb} / \mathrm{Y}$ vs. $\mathrm{Zr} / \mathrm{Ti}$ classifying mafic and intermediate rocks from the A6 Anomaly and Eskay Creek, (b) Zr vs. Y characterizing magmatic affinity of mafic and intermediate lithologies. Rock classification diagram after [57], magmatic affinity for alkaline rocks using Zr/Y ratios of [53]. Note: Group A basalts from the A6 Anomaly and Group 1 basalts from the Eskay rift [10] are almost identical in their composition and hence overlap in particular in (a) resulting that data of Group 1 are partially obscured by Group A basalts since focus is on lithologies of the A6 Anomaly. 
The mafic and intermediate igneous rocks from the A6 Anomaly can be divided into basaltic flows with their volcaniclastic counterparts and dolerite dykes. Flows and volcaniclastic rocks are further divided into: (1) Group A basalts, (2) Group B basalts, and (3) Group B andesites. This distinction is purely geochemically, since Group A and $B$ basalts can have the same texture (Figure $6 \mathrm{~d}, \mathrm{e}$ ) and are indistinguishable from each other macroscopically. Group A basalts are more common on the west and east flanks and commonly occur with mudstones close to the surface and hence higher up in the stratigraphy (Figure 4). Group B basalts are the dominant mafic lithology in the hanging wall of the altered felsic flows and are volumetrically less common on the east and west side where they also occur with Group B andesites (Figure 4).

Geochemically, Group A basalts are tholeiitic $(\mathrm{Zr} / \mathrm{Y}<2.8$; [53]; Figure 10a,b) with $\mathrm{Nb} / \mathrm{Yb}<1.6$, lowest $\mathrm{SiO}_{2}, \mathrm{Al}_{2} \mathrm{O}_{3}$, intermediate $\mathrm{TiO}_{2}$, and highest $\mathrm{Fe}_{2} \mathrm{O}_{3}(\mathrm{t})$ composition among mafic and intermediate lithologies (Figure 11a,b, Table 2). The Mg\# for Group A basalts varies between 33 and 70 (Figure 11c). Group B basalts are transitional $(\mathrm{Zr} / \mathrm{Y}=2.8-4.5)$ to calc-alkaline $(\mathrm{Zr} / \mathrm{Y}>4.5$; [53]; Figure 10a,b) with $\mathrm{Nb} / \mathrm{Yb}>2.2$, intermediate $\mathrm{SiO}_{2}, \mathrm{Al}_{2} \mathrm{O}_{3}$ and $\mathrm{Fe}_{2} \mathrm{O}_{3}(\mathrm{t})$, and highest $\mathrm{TiO}_{2}$ composition among the mafic and intermediate lithologies (Figure 11a,b, Table 2). The Mg\# for Group B basalts is lower than in Group A basalts and varies between 21 and 58 (Figure 11c). Group B andesites are calc-alkaline $\left(\mathrm{Zr} / \mathrm{Y}>4.5\right.$; [53]) with $\mathrm{Nb} / \mathrm{Yb}>3.5$ (Figure 10a,b), highest $\mathrm{SiO}_{2}$ and $\mathrm{Al}_{2} \mathrm{O}_{3}$, and intermediate $\mathrm{TiO}_{2}$ and $\mathrm{Fe}_{2} \mathrm{O}_{3}(\mathrm{t})$ composition of the mafic to intermediate lithologies (Figure 11a,b, Table 2); they have a Mg\# similar to Group B basalts ranging between 25 to 45 (Figure 11c). Carbon content in mafic and intermediate rocks is higher than in the altered felsic units due to calcite commonly occurring in vesicles (Figure $6 \mathrm{~d}, \mathrm{e}$ ), whereas the $S$ content is lower, since sulfide minerals are largely absent (Table 2). Loss in ignition is relatively high in Group A and Group B basalts (Table 2) due to hydrous phases including chlorite and zeolites.

Similar to major elements, Group A and Group B lithologies differ strongly from each other in trace element content including transition metals $\mathrm{Cr}, \mathrm{Co}, \mathrm{Ni}$, and V (Figure 11d,e, Table 2, Supplementary Materials Table S5) that are decreasing from Group A basalts to Group B basalts to Group B andesites. High field strength element content including Zr, $\mathrm{Y}, \mathrm{Nb}$ and Ta increases from Group A basalts to Group B andesites; average Zr content is $50.8 \pm 9.96$ ppm, $125 \pm 27.6$ ppm and $227 \pm 34.3$ ppm for Group A basalts, Group B basalts and Group B andesites, respectively (Figure 11f, Table 2). Group A basalts have also lowest $\mathrm{Zr} / \mathrm{Ti}$ and $\mathrm{La} / \mathrm{Sm}$ ratios, Group B basalts are intermediate and Group B andesites have the highest $\mathrm{Zr} / \mathrm{Ti}$ and $\mathrm{La} / \mathrm{Sm}$ ratios (Figure 11h,I; Table 2).

Group A basalts REE patterns show minimal REE fractionation with a slight decrease from LREEs towards HREE and no distinct $\mathrm{Ce}$ or Eu anomalies (Figure 12a; Table 2). Group $B$ basalts and andesites have identical REE patterns with overall higher REE contents for andesites (Figure 12b, Table 2). The REE pattern for both types strongly decrease from LREE towards HREE with no distinct Ce or Eu anomalies (Figure 12b, Table 2). Light REE fractionation is $2.29 \pm 0.38$ and $2.92 \pm 0.28$ for Group B basalts and andesites, respectively and HREE fractionation is $1.65 \pm 0.25$ and $1.4 \pm 0.09$ for Group B basalts and andesites, respectively.

Dykes I-a and I-b are geochemically similar to each other and Group A basalts: (1) they are tholeiitic basalts (Figure 10), (2) have $\mathrm{Nb} / \mathrm{Yb}<1.6$ and similar major and trace element composition and ratios than Group A basalts (Figure 11); and (3) show a similar REE pattern with overall flat REE patterns (Figure 12c). A negative Eu anomaly can occur in I-b dolerites. In contrast, type II dolerite is an alkali basalt (Figure 10) with $\mathrm{Nb} / \mathrm{Yb}>8$ and with similar major to trace element content as Group B rocks (Figure 11). The REE pattern of type II dolerite strongly decreases from LREE to HREE and there are no distinct Ce or Eu anomalies (Figure 12d, Table 2). 

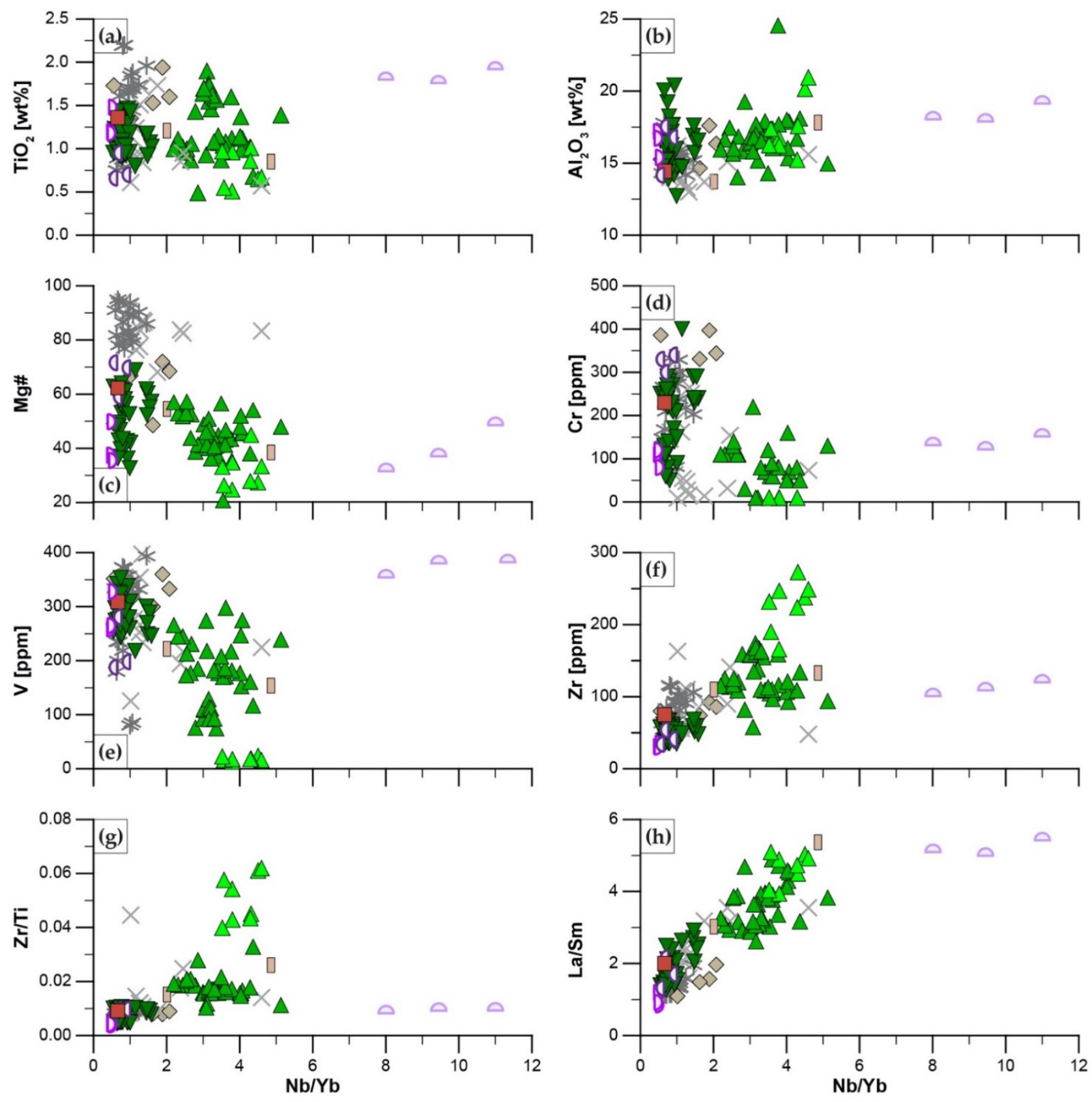
A6 Anomaly mafic and intermediate units Flows and volcaniclastic rocks
Dykes
$\nabla$ Group A basalts
0 Dyke I-a
$\triangle$ Group $B$ basalts
D Dyke I-b
$\triangle$ Group $B$ andesites
- Dyke II

Eskay Rift

Basalt [10]

* Group 1 (South)

$\times$ Group 2 (North)

Figure 11. Bivariate plots of mafic lithologies from the A6 Anomaly, Eskay Creek (with data from [40], and this study) and the Eskay rift [10] for selected major, minor and trace elements, and element ratios versus $\mathrm{N} / \mathrm{Yb}$. (a) $\mathrm{TiO}_{2}[\mathrm{wt} \%]$, (b) $\mathrm{Al}_{2} \mathrm{O}_{3}[\mathrm{wt} \%],(\mathbf{c}) \mathrm{Mg} \#\left(\mathrm{Mg} \#=100 \times\left[\operatorname{molar}\left(\mathrm{Mg}^{2+} /\left(\mathrm{Mg}^{2+}+\mathrm{Fe}^{2+}\right)\right]\right),(\mathbf{d}) \mathrm{Cr}[\mathrm{ppm}],(\mathbf{e}) \mathrm{V}\right.$ [ppm], (f) $\mathrm{Zr}[\mathrm{ppm}],(\mathrm{g}) \mathrm{Zr} / \mathrm{Ti}$, (h) La/Sm. Note: Group A basalts from the A6 Anomaly and Group 1 basalts from the Eskay rift [10] are almost identical in their composition and hence overlap in most plots resulting that data of Group 1 are partially obscured by Group A basalts since focus is on lithologies of A6 Anomaly. 

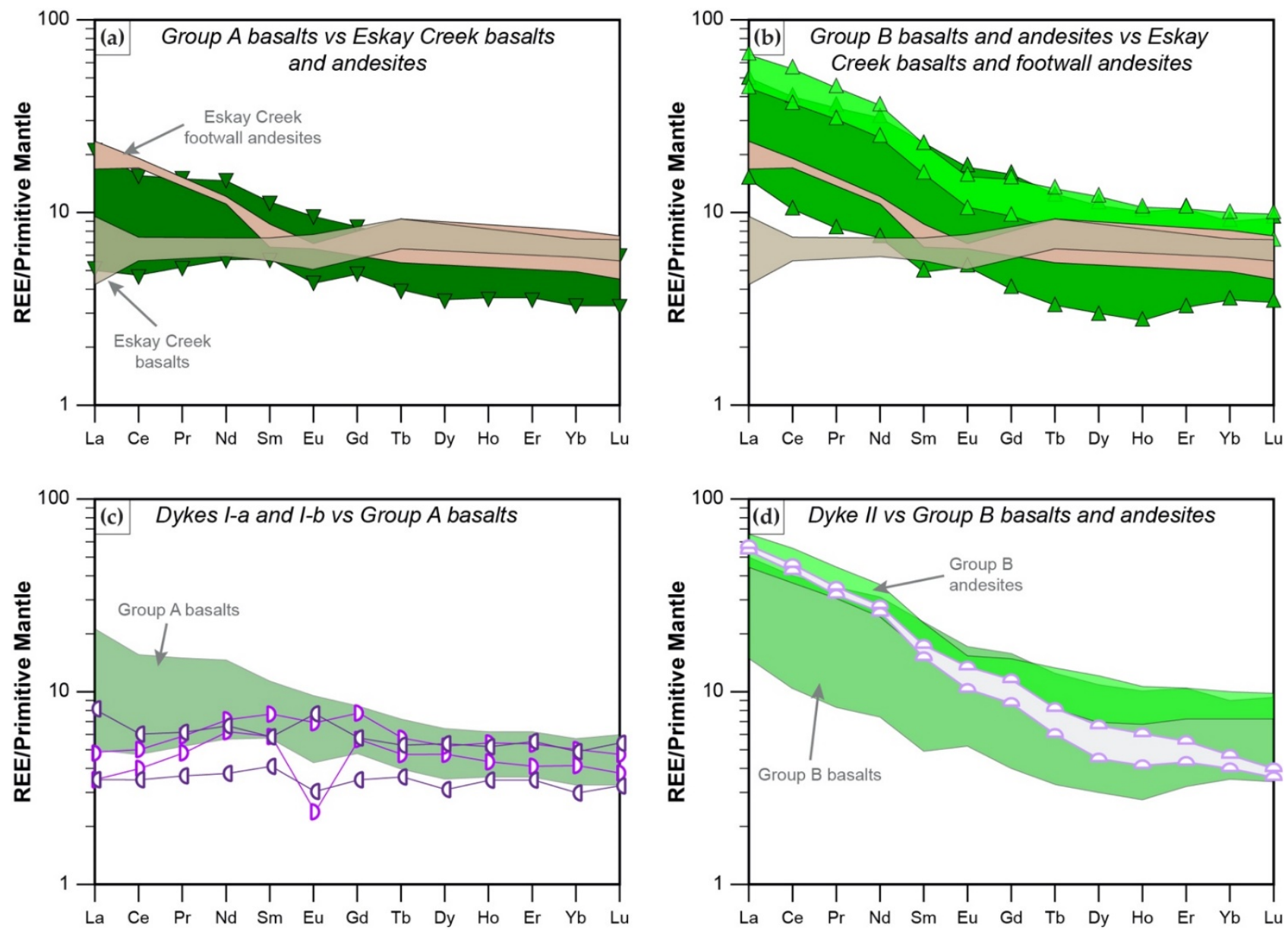

A6 Anomaly intermediate and mafic units
Flows and volcaniclastic rocks
$\square$ Dykes
$\square$ Group A basalts

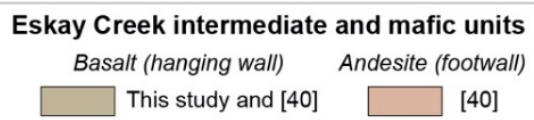

Figure 12. Spider diagrams of REEs normalized to primitive mantle [58] for the different mafic and intermediate units at the A6 Anomaly, (a) Group A basalts in comparison to Eskay Creek basalts and andesites, (b) Group B basalts and andesites in comparison to Eskay Creek basalts and andesites, (c) dykes I-a and I-b dolerites in comparison to Group A basalts, (d) dyke II dolerite in comparison to Group B basalts and andesites. Note: REE patterns for Group 1 and Group 2 basalts [10] overlap with Group A basalts and are not shown here since emphasis is on lithologies of the A6 Anomaly.

The metal content for Group A and Group B lithologies and dolerite dyke types I and II is in the lower ppm level for base metals $\mathrm{Cu}, \mathrm{Zn}$, and $\mathrm{Pb}$, whereas precious metals are below the detection limit in all mafic to intermediate units (Supplementary Materials Table S4). There is no pervasive mineralization in these lithological units and sulfide mineralization is absent; hence, the trace $\mathrm{Cu}, \mathrm{Zn}$, and Pb levels are likely due to trace concentrations in the mafic minerals.

\subsection{Alteration Mineralogy}

\subsubsection{SEM}

Optical microscopy and SEM studies show that the felsic flows have an alteration assemblage of quartz and sericite, minor K-feldspar, and trace chlorite, pyrite, calcite, rutile, barite, and hematite [59] (Figures 13-15). 


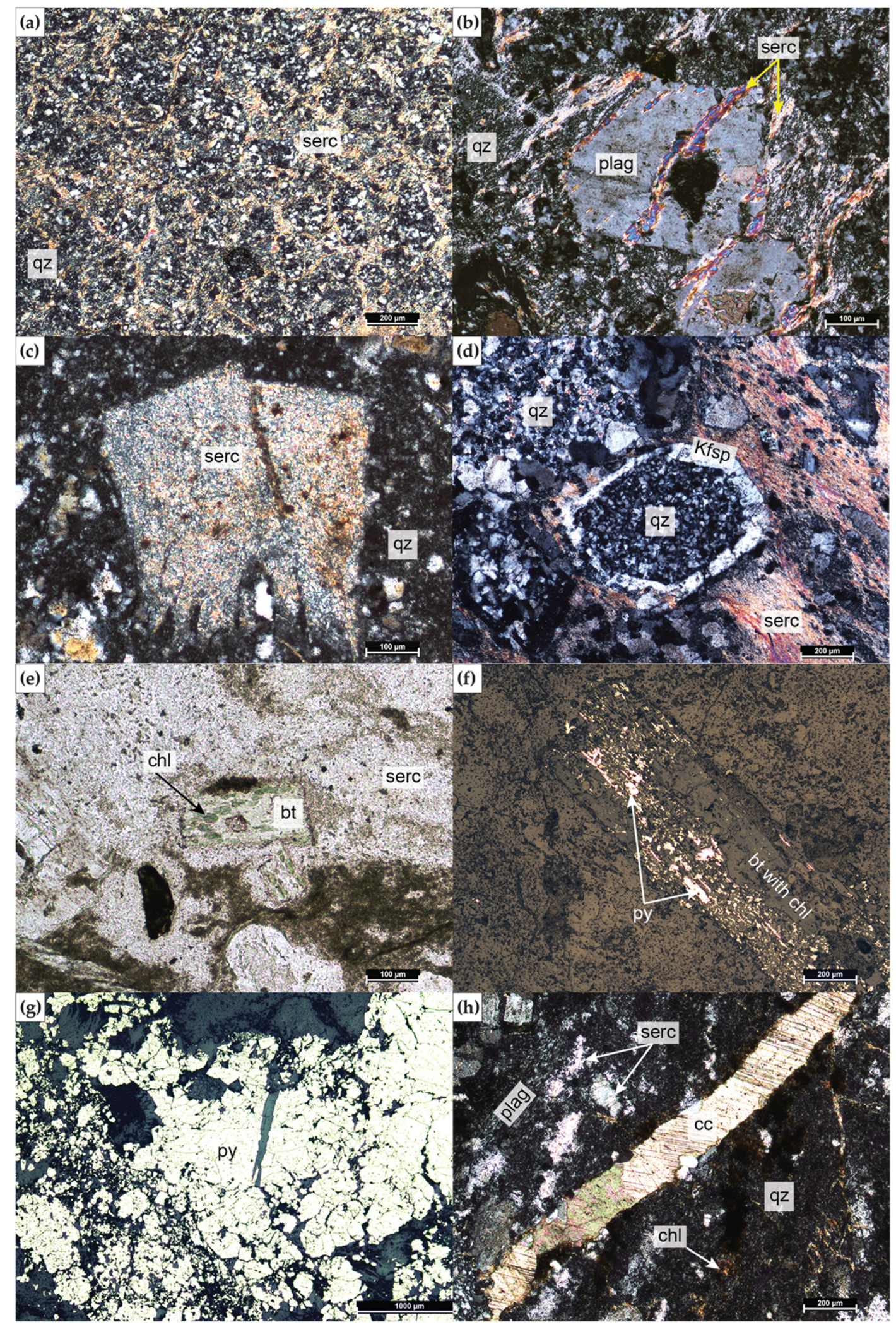

Figure 13. Alteration assemblage and texture in altered felsic units, (a) pervasive sericite and quartz alteration, (b) plagioclase phenocrysts in quartz-sericite altered matrix and partly altered to sericite, (c) completely sericitized feldspar phenocryst in quartz-sericite matrix, (d) plagioclase pseudomorph with quartz core and rim of secondary K-feldspar in sericite-quartz matrix, (e) biotite partly altered to chlorite, (f) pyrite in partly chloritized biotite, (g) anhedral pyrite aggregate, (h) calcite veinlet cross-cutting sericitized plagioclase in quartz-sericite-chlorite matrix. Abbreviations: bt—biotite, chl一chlorite, cc—calcite, K-fsp—K-feldspar, plag—plagioclase, py—pyrite, qz—quartz, serc—sericite. 


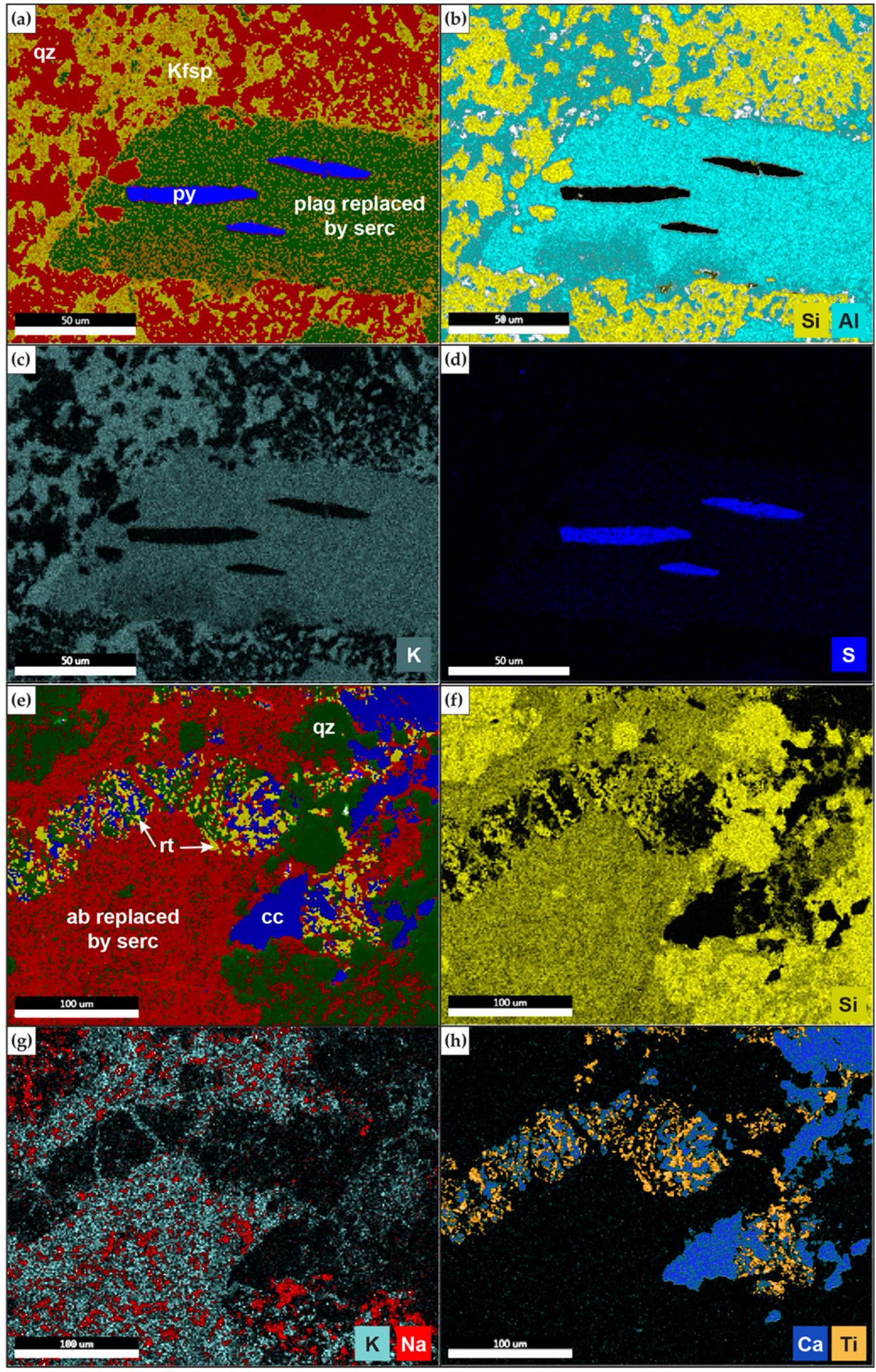

Figure 14. Elemental maps, (a-d) sericitization of plagioclase with orthoclase rim and pyrite inclusions (S825792, BR-79), (a) elemental map of alteration phases present, (b) Si and Al highlighting occurrence of quartz, K-feldspar and sericite, (c) K highlighting occurrence of K-feldspar and sericite both replacing plagioclase, (d) S highlighting pyrite inclusions within sericite, $(\mathbf{e}-\mathbf{g})$ sericitization of albite surrounded by quartz, calcite and rutile (S825756, BR-74), (e) elemental map of alteration phases present, (f) Si highlighting occurrence of quartz (bright lime), albite and sericite (darker lime), (g) K and $\mathrm{Na}$ highlighting occurrence of albite $(\mathrm{Na})$ that is almost completely replaced by sericite (K), (h) Ca and Ti highlighting intergrowth of secondary calcite (blue) and rutile (orange) between sericite and quartz. Abbreviations: ab-albite, cc-calcite, Kfsp-K-feldspar, plag—plagioclase, py—pyrite, qz-quartz, rt—rutile, serc—sericite. 
Mineral phase

Albite
Plagioclase
Biotite
Clinopyroxene
Zircon
Quartz
Illite (sericite)
K-feldspar
Chlorite
Pyrite
Calcite
Rutile
Barite
Hematite

Primary

$$
\begin{aligned}
& \text { Secondary } \\
& \text { early late }
\end{aligned}
$$

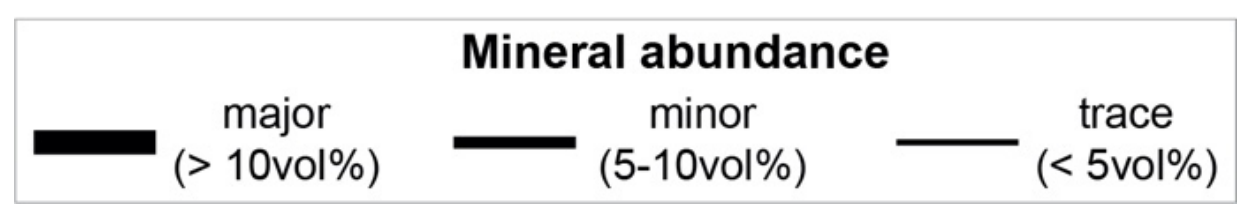

Figure 15. Primary (igneous) and secondary (alteration) minerals of altered felsic flows and their paragenesis.

Quartz occurs both as primary and secondary (i.e., alteration) phase. As an alteration phase, it has a saccharoidal, very fine-grained texture which is common with sericite (Figure 13a-d), or single clusters of larger grains (Figures 13b,d and 14a,b,e,f), and can replace plagioclase (Figure $13 \mathrm{~d}$ ). It is the dominant alteration mineral.

The dominant K-bearing and second most abundant alteration phase is sericite or illite. Sericite is used solely as textural term here, referring to a fine-grained, K-bearing sheet silicate formed from the alteration of feldspar, whereas illite refers to its chemical composition. Sericite occurs in various textures in the felsic units including: (1) pervasive alteration intergrown with quartz \pm K-feldspar (Figure 13a-d), (2) thin veinlets crosscutting and/or rimming plagioclase (Figure 13b), and (3) (almost) complete replacement of plagioclase (Figures 13c,h and $14 \mathrm{a}-\mathrm{c}$ ) and albite (Figure $14 \mathrm{e}, \mathrm{g}$ ).

Feldspars are common primary and secondary alteration phases. Euhedral to subhedral albite and to lesser extent Na-rich plagioclase are primary phases, whereas secondary K-feldspar replaces plagioclase as fine rims around plagioclase pseudomorphs (Figures $13 \mathrm{~d}$ and $14 \mathrm{a}-\mathrm{c}$ ) or is intergrown with quartz in the matrix (Figure 14a,c). However, K-feldspar is only a minor to trace alteration phase.

Chlorite is a trace phase partially replacing biotite in irregular patches (Figure 13e,f). Pyrite is the only sulfide phase recognize and occurs as fine disseminated anhedral grains either within the quartz-sericite $\pm \mathrm{K}$-feldspar matrix, as inclusions in biotite (Figure 13f) 
and sericitized plagioclase (Figure 14a,d) replacing these primary phases, or as fine stringers. Less commonly, aggregates of anhedral pyrite occur (Figure 13g). These larger aggregates occur in zones with relatively high pyrite occurrence $(>5 \mathrm{vol} \%)$ within the altered flows (Figure 4).

Calcite is a late alteration phase forming small veinlets that cross-cut altered matrix (Figures $13 \mathrm{~h}$ and $14 \mathrm{e}, \mathrm{g}, \mathrm{h}$ ). Single calcite grains occurring interstitially between sericitized feldspar and quartz are less common (Figure 14e,h).

Rutile is a late trace alteration phase that forms small, subhedral to anhedral grains that can occur with calcite veinlets (Figure 14e,h) or as single grains with ilmenite lamellae within the quartz-sericite matrix.

Barite and hematite, identified via XRD, may be present as well, but were not observed microscopically.

\subsubsection{XRD}

The mineralogical composition of the altered flows and tuffs is relatively homogeneous and dominated by quartz, albite, and illite (Supplementary Materials Table S5 and Figure S1). Only two samples show significantly less albite $(<1 \mathrm{wt} \%)$, and are instead dominated by orthoclase and illite due to strong alteration. Semiquantitative XRD analyses confirm the occurrence of several trace phases including pyrite, Fe-chlorite, calcite, and rutile, whereas barite and hematite were only detected by XRD. Fe-chlorite and pyrite are not widespread alteration phases; however, their abundance can exceed $5 \mathrm{vol} \%$ locally, and is related to pyrite stringer zones (Figure 4).

The spectra of selected samples highlight selected peaks of illite, Fe-chlorite, pyrite, and calcite (Figure 16). Samples were not further treated by ethylene glycol to distinguish between white mica (i.e., muscovite), illite, and illite/smectite (I/S), as this is difficult due to their similar composition and crystal structure. However, based on EMPA analyses (see below), the composition of the sericite phase is illite with varying I/S components rather than muscovite.

The reflections for illite are at $9.98833 \AA, 4.94266 \AA, 4.7424 \AA$ and $2.55743 \AA$ which correspond to crystal faces $\{002\},\{004\},\{110\}$ and $\{131\}$, respectively. Powder XRD identified an Fe-chlorite of chamosite $\left[\mathrm{Fe}^{2+}{ }_{3} \mathrm{Mg}_{1.5} \mathrm{AlFe}^{3+}{ }_{0.5} \mathrm{Si}_{3} \mathrm{AlO}_{12}(\mathrm{OH})_{6}\right]$ composition in some samples. The peaks are at $14.19753 \AA, 7.08170 \AA$ and $3.53633 \AA$ which correspond to crystal faces $\{001\},\{002\}$ and $\{004\}$, respectively. Pyrite shows reflections at $3.13008 \AA, 2.7094 \AA$, $2.42363 \AA, 2.21265 \AA, 1.91606 \AA$ and $1.63387 \AA$ corresponding to crystal faces $\{111\},\{200\}$, $\{210\},\{211\},\{200\}$ and $\{311\}$, respectively. Calcite has a significant reflection of $3.03026 \AA$ in most samples displaying $\{104\}$ crystal face. The major phases show no significant change in intensity spatially which reflects the rather homogeneous and pervasive alteration of the rhyodacitic to trachytic flows and tuffs at the A6 Anomaly.

\subsection{EMPA}

The detailed compositions of K-feldspar, illite, and pyrite are provided in Supplementary Materials Table S6a-c. The composition of illite is summarized in Table 3, since it is the most abundant alteration phase. Feldspar $(n=23)$ is of orthoclase composition with an average formula of $\left(\mathrm{K}_{0.84}, \mathrm{Na}_{0.03}\right)_{\Sigma 0.87} \mathrm{Al}_{0.97} \mathrm{Si}_{3.06} \mathrm{O}_{8}$. Sodium is a trace phase that commonly has a concentration of $<0.6 \mathrm{wt} \%$, with the exception of one analysis that yielded $1.17 \mathrm{wt} \% \mathrm{Na}_{2} \mathrm{O}$. 


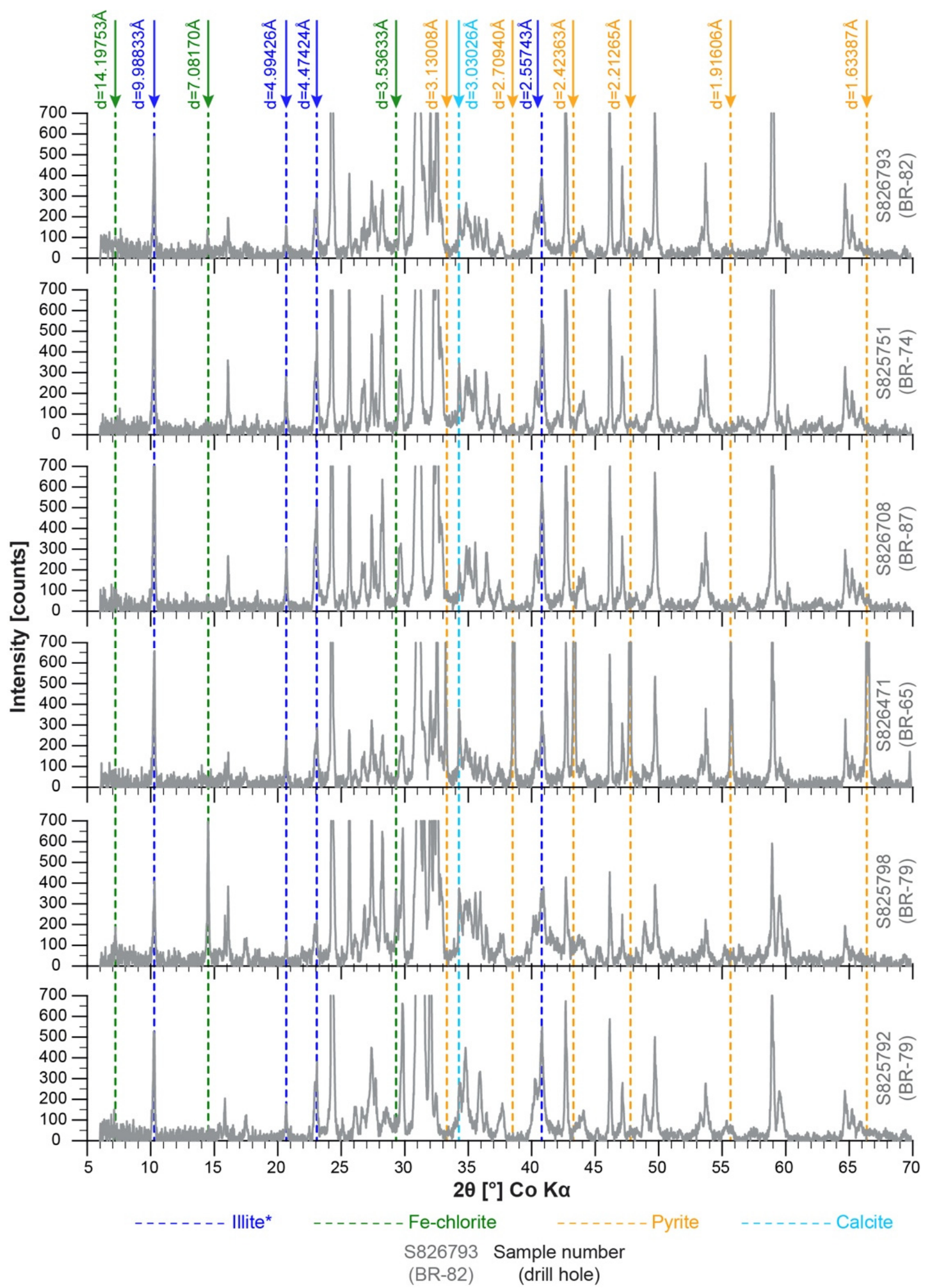

Figure 16. XRD spectra for random oriented samples of $<2 \mu \mathrm{m}$ fraction (untreated, air dried) of felsic volcanic rocks. Peaks and d spacings for selected phases are highlighted in dashed lines and arrows, respectively. Note: * XRD identified muscovite; however, EMPA shows illite composition, and both spectra are very similar and cannot be distinguished by powder XRD based on the applied method. 
Analyses on sericite $(\mathrm{n}=102)$ yielded an illite composition with an average formula of $\left(\mathrm{K}_{0.67}, \mathrm{Na}_{0.03}, \mathrm{Ca}_{0.01}\right)_{\Sigma 0.70}\left(\mathrm{Al}_{1.38}, \mathrm{Fe}_{0.10}, \mathrm{Mg}_{0.15}\right)_{\Sigma 1.63}\left(\mathrm{Al}_{0.65}, \mathrm{Si}_{2.94}\right)_{\Sigma 3.59}(\mathrm{OH})_{1.48}$. All illite analyses have deficiencies both on the tetrahedral and octahedral sites (Figure 17a,b) due to relatively low $\mathrm{SiO}_{2}$ and $\mathrm{Al}_{2} \mathrm{O}_{3}$ concentrations (Table 3). The cause for this deficiency may be related to grain orientation and size and hence, affect analysis conditions, rather than representing structural deficiencies. However, no further investigations were done to test this theory. Besides $\mathrm{Al}$, the octahedral site is occupied by $\mathrm{Fe}^{2+}$ and $\mathrm{Mg}$ (Table 3). Despite a weak enrichment in Fe that can result in up to 0.20 atoms per formula unit (apfu), these illites are not Fe-rich illite sensu stricto [60] that commonly occur in various unconsolidated sedimentary environments including marine shales [61]. Observed deficiencies on the interlayer site (Figure 17c; Table 3) are common for illite [62,63]. Within the interlayer cations, $\mathrm{K}$ varies between 0.60 to 0.84 apfu K (Figure 18) forming both layered illite-smectite (I/S; $\mathrm{K}=0.5-0.69 \mathrm{apfu} ;[64,65])$ and almost pure endmember illite ( $\mathrm{K}=0.88 \mathrm{apfu} ;[66-68])$.

Pyrite analyses $(n=72)$ showed a homogeneous pyrite composition independent of texture with an average formula of $\mathrm{Fe}_{0.99} \mathrm{~S}_{2.00}$ averaging $53.78 \pm 0.65 \mathrm{wt} \% \mathrm{~S}$ and $46.34 \pm 0.34 \mathrm{wt} \%$ Fe. Frequent enrichments in trace metals are rare, with the exception of As that can have concentrations of up to $3.9 \mathrm{wt} \%$ and an average of $0.37 \pm 0.63 \mathrm{wt} \%$, either due to micro-inclusions of arsenopyrite or the incorporation of As within the pyrite structure [69]. Cobalt concentrations in two grains reach 0.05 and $0.07 \mathrm{wt} \%$ and occur in pyrite with measurable As concentrations. Trace concentrations of $\mathrm{Cu}, \mathrm{Zn}$, and $\mathrm{Pb}$ in a limited number of grains are likely due to micro-inclusions of chalcopyrite, sphalerite, and galena, respectively.
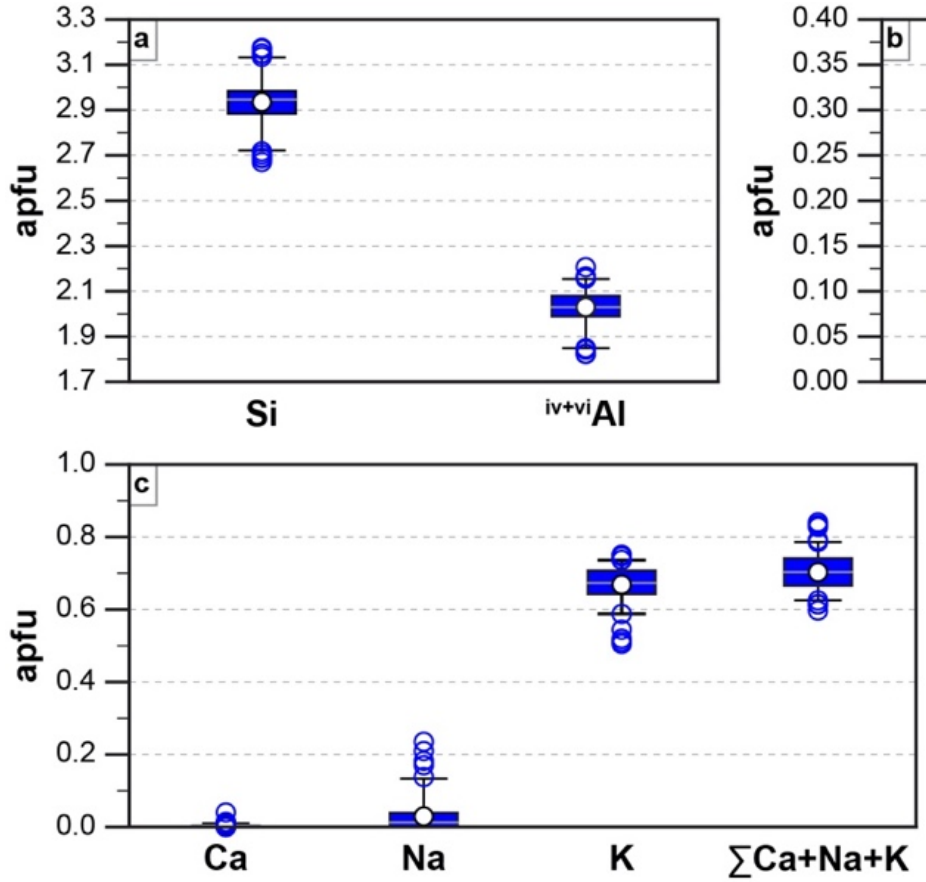
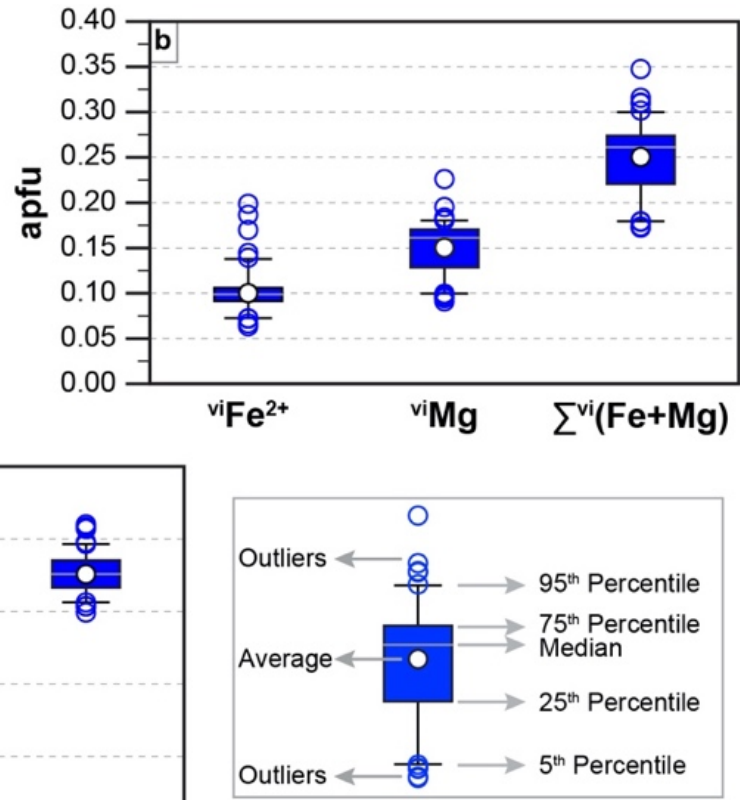

Figure 17. Box-Percentile plots showing range in major and minor elements in apfu within analyzed illite. (a) Si and total $\mathrm{Al}$; (b) Elements $\mathrm{Fe}^{2+}$ and $\mathrm{Mg}^{2+}$ on the octahedral site and their sum; (c) Elements $\mathrm{Ca}, \mathrm{Na}$, and $\mathrm{K}$ on the interlayer site and their sum. 
Table 3. Summary of illite $(n=102)$ composition analyzed via EMPA in felsic volcanic rocks. Temperature calculation after [70]. Abbreviations: apfu—atoms per formula unit, Max—maximum value, Min—minimum value, Stddev—standard deviation.

\begin{tabular}{|c|c|c|c|c|}
\hline Element & Average & Stddev & Min & Max \\
\hline $\mathrm{SiO}_{2}[\mathrm{wt} \%]$ & 50.02 & 1.52 & 45.78 & 54.16 \\
\hline $\mathrm{Al}_{2} \mathrm{O}_{3}$ & 29.36 & 1.06 & 26.42 & 32.33 \\
\hline $\mathrm{FeO}(\mathrm{t})$ & 2.04 & 0.41 & 1.32 & 4.09 \\
\hline $\mathrm{MgO}$ & 1.72 & 0.30 & 1.05 & 2.58 \\
\hline $\mathrm{CaO}$ & 0.08 & 0.07 & 0.00 & 0.64 \\
\hline $\mathrm{Na}_{2} \mathrm{O}$ & 0.26 & 0.40 & 0.00 & 2.09 \\
\hline $\mathrm{K}_{2} \mathrm{O}$ & 8.93 & 0.59 & 6.82 & 9.85 \\
\hline $\mathrm{Cr}_{2} \mathrm{O}_{3}$ & 0.01 & 0.01 & 0.00 & 0.04 \\
\hline $\mathrm{SO}_{3}$ & 0.02 & 0.06 & 0.00 & 0.63 \\
\hline $\mathrm{CuO}$ & 0.02 & 0.02 & 0.00 & 0.11 \\
\hline Total & 92.45 & 1.11 & 90.09 & 95.56 \\
\hline $\mathrm{H}_{2} \mathrm{O} \_$calc & 7.55 & 1.11 & 4.44 & 9.91 \\
\hline $\mathrm{Na}_{2} \mathrm{O}+\mathrm{K}_{2} \mathrm{O}$ & 9.19 & 0.54 & 8.00 & 10.54 \\
\hline \multicolumn{5}{|c|}{ Based on 11 oxygen atoms } \\
\hline Si [apfu] & 2.94 & 0.10 & 2.67 & 3.17 \\
\hline iv $\mathrm{Al}$ * & 0.65 & 0.00 & 0.65 & 0.65 \\
\hline Subtotal & 3.59 & 0.10 & 3.32 & 3.82 \\
\hline${ }^{\mathrm{vi}} \mathrm{Al}$ & 1.38 & 0.08 & 1.17 & 1.56 \\
\hline $\mathrm{Fe}^{2+* *}$ & 0.10 & 0.02 & 0.06 & 0.20 \\
\hline $\mathrm{Mg}$ & 0.15 & 0.03 & 0.09 & 0.23 \\
\hline Sum Octahedral & 1.63 & 0.08 & 1.36 & 1.74 \\
\hline $\mathrm{R}^{2+}=\mathrm{Fe}+\mathrm{Mg}$ & 0.25 & 0.04 & 0.17 & 0.35 \\
\hline${ }^{\mathrm{vi}} \mathrm{R}^{2+} /\left({ }^{\mathrm{vi}} \mathrm{R}^{2+}+{ }^{\mathrm{vi}} \mathrm{R}^{3+}\right) \leq 0.25$ & 0.15 & 0.02 & 0.10 & 0.23 \\
\hline $\mathrm{Ca}$ & 0.01 & 0.00 & 0.00 & 0.04 \\
\hline $\mathrm{Na}$ & 0.03 & 0.05 & 0.00 & 0.24 \\
\hline $\mathrm{K}$ & 0.67 & 0.05 & 0.50 & 0.75 \\
\hline Sum Interlayer & 0.70 & 0.05 & 0.60 & 0.84 \\
\hline Total_no water & 5.92 & 0.13 & 5.65 & 6.26 \\
\hline $\mathrm{OH}$ & 1.48 & 0.20 & 0.89 & 1.90 \\
\hline Al_total & 2.03 & 0.08 & 1.82 & 2.21 \\
\hline $\mathrm{Cr}$ & 0.00 & 0.00 & 0.00 & 0.00 \\
\hline $\mathrm{S}$ & 0.00 & 0.00 & 0.00 & 0.03 \\
\hline $\mathrm{Cu}$ & 0.00 & 0.00 & 0.00 & 0.00 \\
\hline $\mathrm{x}=\mathrm{K}+|\mathrm{Fe}-\mathrm{Mg}|$ & 0.72 & 0.06 & 0.53 & 0.83 \\
\hline $\mathrm{T}\left[{ }^{\circ} \mathrm{C}\right]=267.95 \mathrm{x}+31.50$ & 225 & 16 & 173 & 253 \\
\hline
\end{tabular}

* Composition for $\mathrm{Al}$ octahedral site was assumed constant with 0.65apfu according to illite composition. ${ }^{* *}$ EMPA cannot distinguish between $\mathrm{Fe}^{2+}$ and $\mathrm{Fe}^{3+}$; however, all analyzed $\mathrm{Fe}$ was assumed to be $\mathrm{Fe}^{2+}$ according to illite composition 


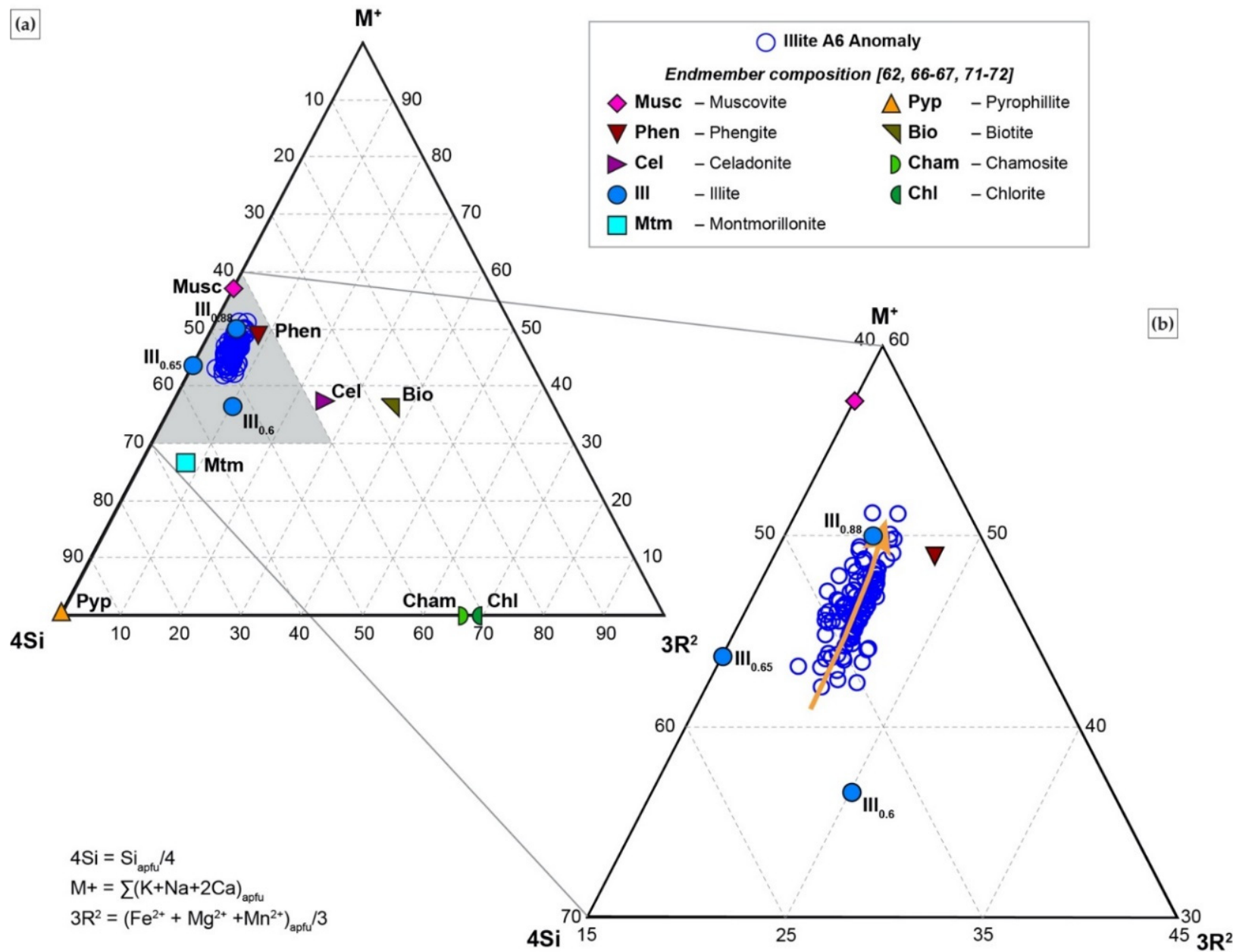

Figure 18. Composition of analyzed illite in $4 \mathrm{Si}-\mathrm{M}+-3 \mathrm{R}^{2}$ ternary plot after [66,71]. Endmember composition of selected micas and clays are given based on $[62,66,67,72]$. (a) Analyzed illites plot in-between illite composition with interlayer charges of $0.6\left(\mathrm{Ill}_{0.6}\right), 0.65\left(\mathrm{Ill}_{0.65}\right)$ and $0.88\left(\mathrm{Ill}_{0.88}\right)$. (b) Close up of (a), illite composition vary between I/S composition $\left(\mathrm{ill}_{0.60-0.65}\right)$ and endmember illite composition $\left(\mathrm{Ill}_{0.88}\right)$ which is a function of increasing temperature (orange arrow).

\subsection{SIMS}

Analyses of 24 illite and 21 quartz grains from three samples from different drill holes yielded average $\mathrm{O}$ isotope composition of $10.7 \pm 3.0 \%$ and $13.4 \pm 1.3 \%$, respectively (Table 4; Figure 19). Oxygen isotope composition in illite predominantly ranges from 6.2 to $14.3 \%$, with one outlier at $21.7 \%$ (Figure $19 a, b$ ). The analyzed illite grains occur as pseudomorphs after feldspar (Figure 19c), fine-grained aggregates in the groundmass (Figure 19c,d), or fine stringers (Figure 19d). Despite textural variations, O isotope composition does not correspond to different textures of illite. The oxygen isotopic composition of altered quartz grains both in the fine matrix and relatively coarse, saccharoidal grains surrounding illite (Figure 19c,d) is homogeneous (Figure 19a), ranging from 11.0 to 15.3\%o, (Figure 19a,b; Table 5), which is higher than the average $\delta^{18} \mathrm{O}$ composition of illite. 
Table 4. Oxygen isotope composition of illite and quartz in felsic volcanic rocks relative to VSMOW. Abbreviations: ${ }^{18} \mathrm{O} /{ }^{16} \mathrm{O}_{\text {Meas }}$-measured ${ }^{18} \mathrm{O} /{ }^{16} \mathrm{O}$ composition, DDH—diamond drill hole, Max-maximum value, Min-minimum value, Stdev—standard deviation.

\begin{tabular}{|c|c|c|c|c|c|c|c|c|}
\hline \multirow[b]{2}{*}{ Sample } & \multicolumn{4}{|c|}{ Illite } & \multicolumn{4}{|c|}{ Quartz } \\
\hline & Spot & ${ }^{18} \mathrm{O} /{ }^{16} \mathrm{O}_{\text {Meas }}$ & $\delta^{18} \mathrm{O}(\%)$ & $1 \sigma(\%)$ & Spot & ${ }^{18} \mathrm{O} /{ }^{16} \mathrm{O}_{\text {Meas }}$ & $\delta^{18} \mathrm{O}(\%)$ & $1 \sigma(\%)$ \\
\hline \multicolumn{9}{|c|}{ DDH BR-79 } \\
\hline S825792 & C2-01 & $1.90 \times 10^{-3}$ & 8.3 & 0.8 & $\mathrm{C} 2-\mathrm{b}$ & $1.89 \times 10^{-3}$ & 13.7 & 0.8 \\
\hline S825792 & C2-02 & $1.90 \times 10^{-3}$ & 7.6 & 0.8 & $\mathrm{C} 2-\mathrm{c}$ & $1.89 \times 10^{-3}$ & 14.6 & 0.8 \\
\hline S825792 & C2-03 & $1.90 \times 10^{-3}$ & 8.6 & 0.8 & $C-2 c 2$ & $1.89 \times 10^{-3}$ & 15.1 & 0.8 \\
\hline S825792 & C2-04 & $1.90 \times 10^{-3}$ & 11.2 & 0.8 & C2-e & $1.89 \times 10^{-3}$ & 12.4 & 0.8 \\
\hline S825792 & C1-01 & $1.90 \times 10^{-3}$ & 8.8 & 0.8 & $C-3 g$ & $1.89 \times 10^{-3}$ & 13.7 & 0.8 \\
\hline S825792 & C1-02 & $1.89 \times 10^{-3}$ & 6.2 & 0.8 & $C-3 e$ & $1.89 \times 10^{-3}$ & 13.9 & 0.8 \\
\hline S825792 & C1-03 & $1.90 \times 10^{-3}$ & 10.2 & 0.8 & C1-a & $1.89 \times 10^{-3}$ & 13.3 & 0.8 \\
\hline S825792 & C1-04 & $1.90 \times 10^{-3}$ & 7.8 & 0.8 & C1-e & $1.89 \times 10^{-3}$ & 13.7 & 0.8 \\
\hline \multicolumn{9}{|c|}{ DDH BR-65 } \\
\hline S826468 & C5-01 & $1.90 \times 10^{-3}$ & 11.6 & 0.8 & C5-a & $1.88 \times 10^{-3}$ & 11.7 & 0.8 \\
\hline S826468 & C5-02 & $1.90 \times 10^{-3}$ & 14.3 & 0.8 & C5-e & $1.88 \times 10^{-3}$ & 11.0 & 0.8 \\
\hline S826468 & C5-03 & $1.90 \times 10^{-3}$ & 9.9 & 0.8 & C5-c & $1.88 \times 10^{-3}$ & 12.1 & 0.8 \\
\hline S826468 & C5-04 & $1.90 \times 10^{-3}$ & 10.3 & 0.8 & C5-f & $1.89 \times 10^{-3}$ & 14.0 & 0.8 \\
\hline S826468 & C1-01 & $1.90 \times 10^{-3}$ & 10.1 & 0.8 & $\mathrm{C} 1-\mathrm{b}$ & $1.89 \times 10^{-3}$ & 14.9 & 0.8 \\
\hline S826468 & C1-02 & $1.90 \times 10^{-3}$ & 10.2 & 0.8 & $\mathrm{C} 1-\mathrm{c}$ & $1.89 \times 10^{-3}$ & 12.6 & 0.8 \\
\hline S826468 & C1-03 & $1.90 \times 10^{-3}$ & 9.4 & 0.8 & C1-d & $1.89 \times 10^{-3}$ & 13.7 & 0.8 \\
\hline S826468 & C1-04 & $1.90 \times 10^{-3}$ & 10.1 & 0.8 & & & & \\
\hline \multicolumn{9}{|c|}{ DDH BR-82 } \\
\hline S826793 & C3-01 & $1.90 \times 10^{-3}$ & 11.8 & 0.8 & C3-d & $1.89 \times 10^{-3}$ & 15.3 & 0.8 \\
\hline S826793 & C3-02 & $1.90 \times 10^{-3}$ & 21.7 & 0.8 & C3-f & $1.88 \times 10^{-3}$ & 14.1 & 0.8 \\
\hline S826793 & C3-03 & $1.90 \times 10^{-3}$ & 12 & 0.8 & C3-g & $1.88 \times 10^{-3}$ & 14.2 & 0.8 \\
\hline S826793 & C3-04 & $1.90 \times 10^{-3}$ & 13.3 & 0.8 & & & & \\
\hline S826793 & C5-01 & $1.90 \times 10^{-3}$ & 13.1 & 0.8 & C5-a & $1.89 \times 10^{-3}$ & 14.7 & 0.8 \\
\hline S826793 & C5-02 & $1.90 \times 10^{-3}$ & 9.6 & 0.8 & C5-f & $1.88 \times 10^{-3}$ & 11.7 & 0.8 \\
\hline S826793 & C5-03 & $1.90 \times 10^{-3}$ & 11.4 & 0.8 & C5-g & $1.88 \times 10^{-3}$ & 11.7 & 0.8 \\
\hline \multirow[t]{5}{*}{ S826793 } & C5-04 & $1.90 \times 10^{-3}$ & 10.2 & 0.8 & & & & \\
\hline & & Average & 10.7 & & & & 13.4 & \\
\hline & & Stdev & 3.0 & & & & 1.3 & \\
\hline & & Min & 6.2 & & & & 11.0 & \\
\hline & & $\operatorname{Max}$ & 21.7 & & & & 15.3 & \\
\hline
\end{tabular}

Table 5. Comparison of selected features for A6 Anomaly and Eskay Creek deposit, compiled with information from this study and $[40,41]$.

\begin{tabular}{|c|c|c|}
\hline Feature & A6 Anomaly & Eskay Creek VMS Deposit \\
\hline Felsic units & $\begin{array}{ll}\text { - } & \text { Calc-alkaline FII with minor FI rhyodacite to } \\
& \text { trachyte } \\
\text { - } & \text { Slightly decreasing REE pattern with weakly } \\
\text { negative Eu anomaly } \\
\text { - } \quad \mathrm{Zr}<200 \mathrm{ppm} \\
\text { - } & \text { I-type (volcanic arc) affinity }\end{array}$ & $\begin{array}{ll}\text { - } & \text { Tholeiitic FIII rhyolite (i.e., 'Eskay rhyolite') } \\
\text { - } & \text { Slightly decreasing REE pattern with strongly } \\
\text { negative Eu anomaly } \\
\text { - } \quad \mathrm{Zr}<200 \text { up to } 400 \mathrm{ppm} \\
\text { - } \quad \text { A-type (within-plate) and anomalous ocean ridge } \\
\text { affinity }\end{array}$ \\
\hline Mafic volcanic units & $\begin{array}{l}\text { - Tholeiitic Group A basalts with } \mathrm{Nb} / \mathrm{Yb}<1.6 \text {, } \\
\text { relatively flat REE pattern and NMORB } \\
\text { signature with UCC assimilation } \\
\text { Transitional to calc-alkaline Group B basalts } \\
\text { and andesites with } \mathrm{Nb} / \mathrm{Yb}>2.2 \text {, steeply } \\
\text { declining REE pattern and EMORB signature } \\
\text { with UCC assimilation }\end{array}$ & $\begin{array}{l}\text { - Tholeiitic hanging wall basalts with } \mathrm{Nb} / \mathrm{Yb}<2 \text {, } \\
\text { relatively flat REE pattern and } \mathrm{NMORB} \text { signature } \\
\text { Tholeiitic footwall andesites with } \mathrm{Nb} / \mathrm{Yb}>2 \text {, } \\
\text { steeply declining REE pattern and EMORB } \\
\text { signature with UCC assimilation }\end{array}$ \\
\hline
\end{tabular}


Table 5. Cont.

\begin{tabular}{|c|c|c|}
\hline Feature & A6 Anomaly & Eskay Creek VMS Deposit \\
\hline Intrusions & $\begin{array}{l}\text { Relatively thick dyke I dolerite similar in } \\
\text { geochemistry to Group A and Eskay Creek } \\
\text { basalts and cross-cutting hanging wall } \\
\text { Thin alkali basalts with } \mathrm{Nb} / \mathrm{Yb}>8 \text { and } \\
\text { similar REE pattern than Group B lithologies } \\
\text { cross-cutting footwall and hanging wall }\end{array}$ & $\begin{array}{l}\text { Relatively thick felsic dykes (felsite) crosscutting } \\
\text { footwall stratigraphy at low angle } \\
\text { Thin basaltic dykes cross-cutting footwall and } \\
\text { hanging wall }\end{array}$ \\
\hline Tectonic setting & $\begin{array}{l}\text { - Back arc basin evolving into a rift (subbasin } \\
\text { east of 'Eskay rift') }\end{array}$ & - $\quad$ Back arc basin rift (i.e., 'Eskay rift') \\
\hline Alteration & $\begin{array}{l}\text { Weak to moderate phyllic alteration of felsic } \\
\text { units (quartz-illite } \pm \text { chlorite } \pm \text { sulfide } \pm \\
\text { calcite } \pm \text { barite } \pm \text { rutile) }\end{array}$ & $\begin{array}{l}\text { Strong phyllic alteration in Eskay } \\
\text { rhyolite(quartz-sericite-pyrite } \pm \text { chlorite) }\end{array}$ \\
\hline Mineralization & $\begin{array}{l}\text { Local, uneconomic pyrite stringer in felsic } \\
\text { units } \\
\text { - } \quad \text { No elevated } \mathrm{Cu}, \mathrm{Zn}, \mathrm{Pb}, \mathrm{Au}, \mathrm{Ag} \text { content }\end{array}$ & $\begin{array}{l}\text { - Sulfosalt-Au-Ag-sulfide mineralization in } \\
\text { rhyolite (stockwork zone) and as } \\
\text { bedding-parallel sulfide lenses in overlying } \\
\text { 'contact mudstone' and less in hanging wall } \\
\text { mudstone } \\
\text { - Elevated } \mathrm{Au}, \mathrm{Ag}, \mathrm{Zn}, \mathrm{Pb} \text { contents }\end{array}$ \\
\hline
\end{tabular}
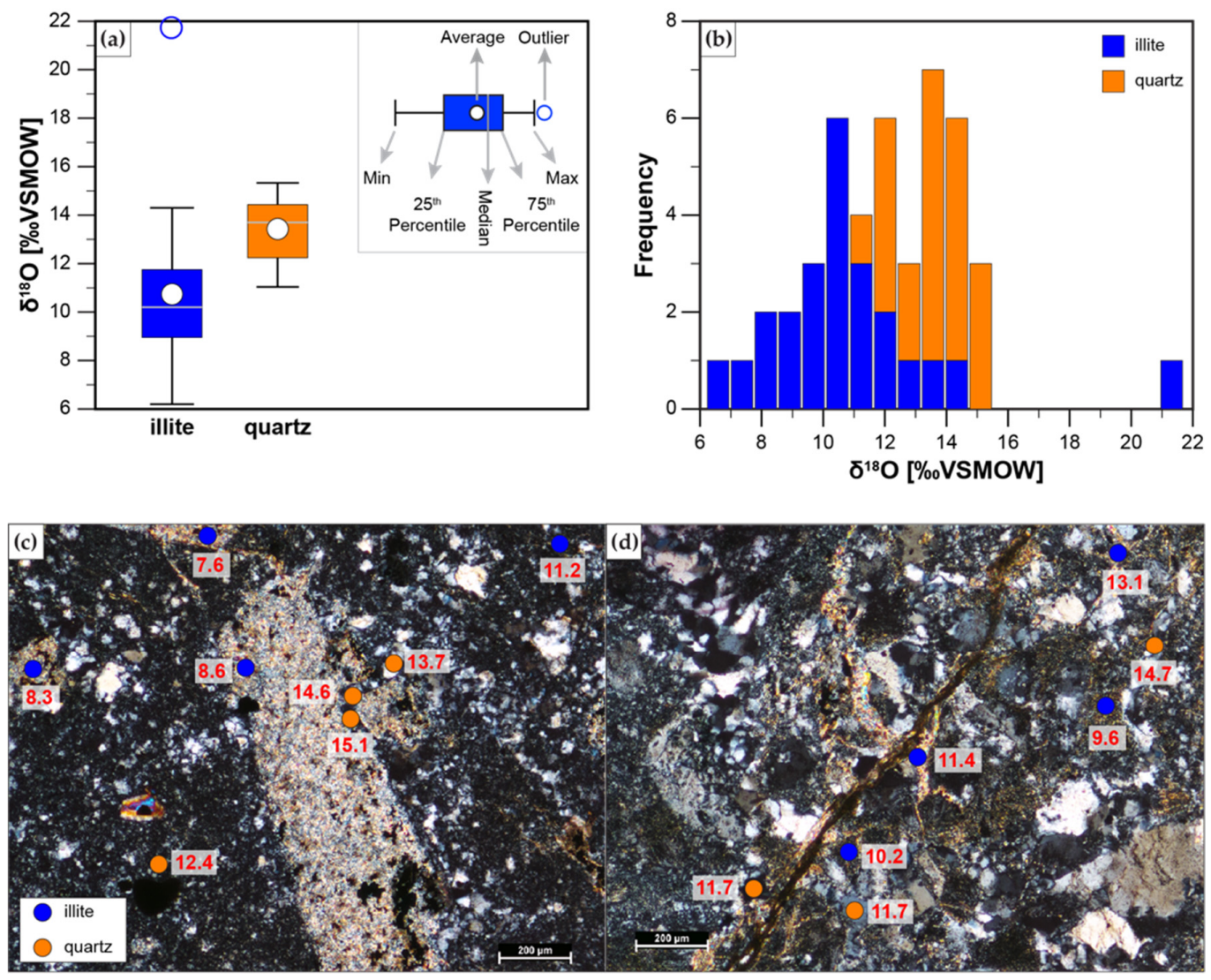

Figure 19. Oxygen isotope composition of illite and quartz in altered flows, (a) Tukey box-whisker plot showing range of $\delta^{18} \mathrm{O}$ composition in both phases, (b) histogram (bin width $0.775 \%$ ), (c) $\delta^{18} \mathrm{O}$ values of illite completely replacing plagioclase phenocryst, quartz surrounding feldspar pseudomorph, and fine-grained quartz-illite matrix (sample S825792, BR-79), (d) $\delta^{18} \mathrm{O}$ values of illite in fine stringer and within altered matrix and relatively fine- to coarse-grained quartz in vicinity of illite (sample S826793, BR-82). 


\section{Discussion}

The results of lithogeochemistry, alteration mineralogy and mineral chemistry, and in situ oxygen isotope geochemistry on illite and quartz are used: (1) to determine the VMS potential of the A6 Anomaly; (2) to compare the A6 Anomaly with the near-by Eskay Creek deposit to provide more details on the tectonic setting of the study area; and (3) to quantify the effects of alteration (i.e., mass changes), determine hydrothermal fluid conditions (e.g., $\mathrm{T}, \mathrm{pH}$ and redox state), and provide a spatial context of the alteration (i.e., distal/proximal footwall vs. hanging wall alteration).

\subsection{Potential for a VMS System}

Exploration for VMS deposits commonly applies the use of geochemistry of felsic and mafic igneous rocks to determine the tectonic setting and fertility of the lithological units (e.g., [73]). The composition of igneous host lithologies provide insights into source region and melting depth of the parent rock and therefore tectonic setting, which is critical to the metal endowment of the lithologies that can host VMS deposits (e.g., [13,15,16,74]). In order to determine to what extent the volcanic rocks of the A6 Anomaly have potential for VMS formation, several geochemical parameters (e.g., Zr/Y, HFSE content, (La. Yb) $)_{\mathrm{n}}, \mathrm{Yb}_{\mathrm{n}}$, $\mathrm{Ti} / \mathrm{V}, \mathrm{Nb} / \mathrm{Yb}, \mathrm{Th} / \mathrm{Yb}$ ) were applied and are shown in Figures 20 and 21.

The felsic units of the A6 Anomaly correspond with rhyolites of FII type and to lesser extent FI type (Figure 20a,b) of Lesher et al. [74] and Hart et al. [13] due to their calc-alkaline affinity, HFSE content and decreasing LREE pattern (Figures $7 \mathrm{~b}, 8 \mathrm{f}-\mathrm{h}$ and 9 , Table 2). Rhyolites of type II are characterized by moderate $\mathrm{Zr} / \mathrm{Y}$ ratios, intermediate abundance of HFSE, and gently sloping REE patterns with variable Eu anomalies [13,74]. Although many felsic Phanerozoic VMS host rocks have FII affinity [75], such as the VMS deposits in the Bathurst camp [76], they are rather complex in evaluating their VMS potential since melting depth at which the parent rock melted vary in FII rhyolites and impact how much heat is generated to the overlying VMS systems (e.g., [13]). Rhyolites of FI type are commonly characterized by high Zr/Y ratio, low abundance of HFSE, and relatively steep REE pattern with weak Eu anomaly (positive or negative; $[13,74])$. They commonly do not host VMS deposits due to their larger melting depth $(>30 \mathrm{~km})$ of the source rock and hence do not provide sufficient heat for a thriving VMS systems and exhibit less metal fertility [13,74]; however, the bimodal-mafic $\mathrm{Cu}(-\mathrm{Au})$ VMS Ming deposit in Newfoundland is hosted by FI rhyolites $[15,16,77,78]$.

Although both fractional crystallization and partial melting have been proposed to form FII rhyolites (e.g., [74,75,79,80]), Hart et al. [13] argued that partial melting at depth of $10-15 \mathrm{~km}$ of an amphibole-plagioclase-bearing precursor is the favorable process to form the geochemical patterns observed in FII rhyolites. Partial melting of such a precursor is likely for the felsic units at the A6 Anomaly as well resulting in the formation of peraluminous (alkali saturation index $>1$ ) rhyodacites to trachytes with moderately depleted HREE (i.e., $\left.(\mathrm{Gd} / \mathrm{Yb})_{\mathrm{n}}=1.16 \pm 0.27\right)$ and $\mathrm{Y}$ and with moderate $\mathrm{Zr} / \mathrm{Y}(8.41 \pm 1.61)$ and $(\mathrm{La} / \mathrm{Yb})_{\mathrm{n}}$ $(8.9 \pm 3.16)$ ratios. The negative $\mathrm{Eu}\left(\mathrm{Eu} / \mathrm{Eu}^{*}=0.59 \pm 0.08\right)$ anomaly is therefore the result of plagioclase in the source rather than plagioclase fractionation. Fractional crystallization trends, in contrast could not be observed from the geochemical composition of the altered felsic units. Moreover, the felsic units at the $\mathrm{A} 6 \mathrm{Anomaly}$ are formed from the same source rock since immobile element ratios (e.g., $\mathrm{Al}_{2} \mathrm{O}_{3} / \mathrm{TiO}_{2}, \mathrm{Al}_{2} \mathrm{O}_{3} / \mathrm{Zr}, \mathrm{Al}_{2} \mathrm{O}_{3} / \mathrm{Nb}, \mathrm{Al}_{2} \mathrm{O}_{3} / \mathrm{Y}$, Figure $8 \mathrm{~b}, \mathrm{f}-\mathrm{h}$ ) are strongly correlated to each other. Although partial melting of an intermediate amphibole-plagioclase-bearing precursor is very likely, contamination by a crustal component cannot be excluded for the altered felsic units at the A6 Anomaly. Despite the potentially favorable FII affinity and geochemical characteristics, the peraluminous rhyodacites and trachytes have a relatively low Zr content $(<200$ ppm) and an I-type (i.e., volcanic arc) affinity that is similar to most barren VMS systems (Figure 20c,d; [15,16]). Additionally, the felsic units are low in base metal content, and mass balance calculations (see below) show a depletion in $\mathrm{Cu}, \mathrm{Zn}$, and $\mathrm{Pb}$ of altered units relative to an unaltered precursor. This indicates low metal fertility within the altered host rocks that are commonly 
also the source of base metals in VMS systems (e.g., [81,82]). A subvolcanic intrusion that was likely the heat source for a VMS system and probably the parent of the altered felsic units was not detected either. This could be, however, due to limited access and depth of drilling.
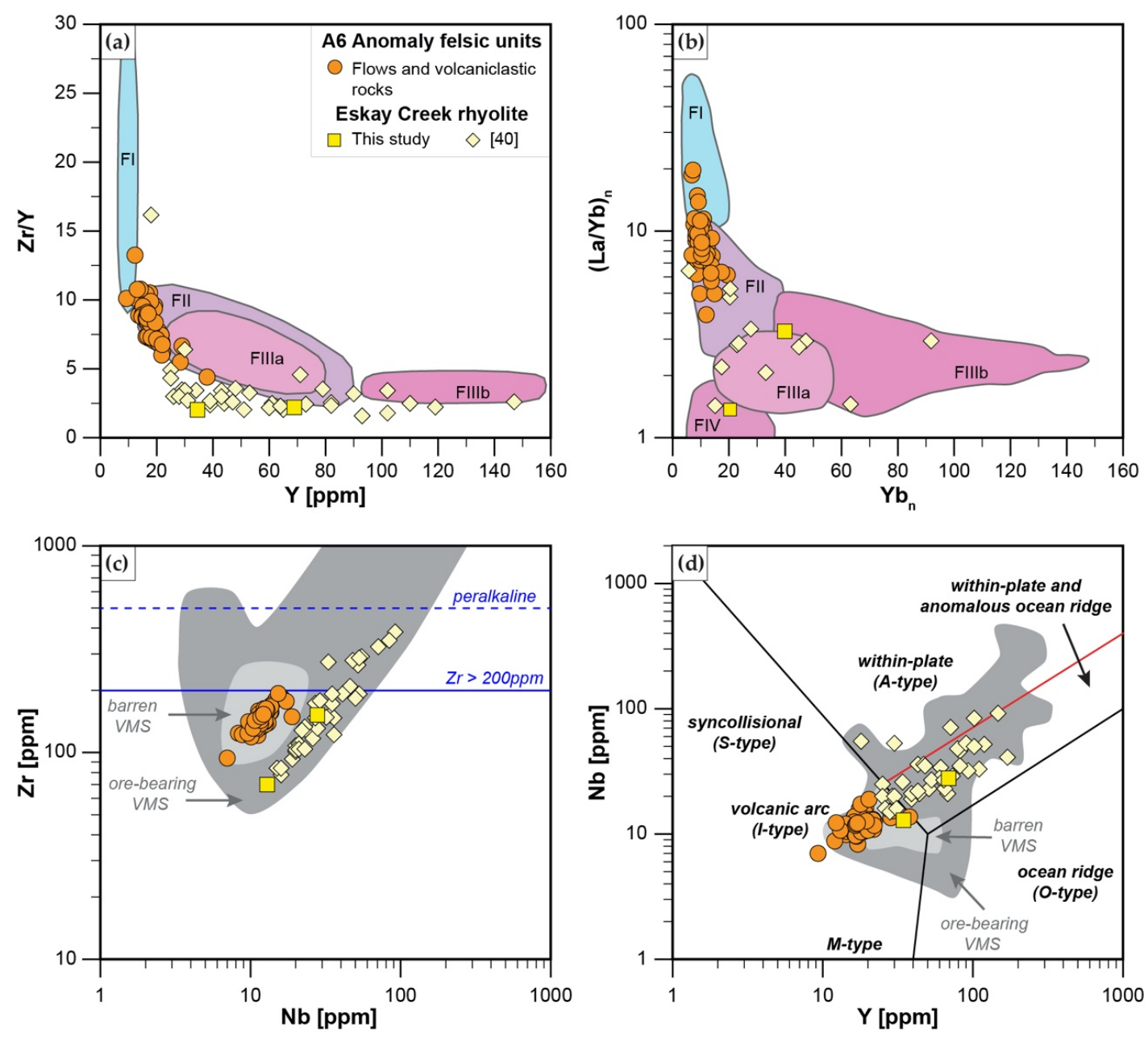

Figure 20. Discrimination of felsic lithologies at A6 Anomaly and Eskay Creek regarding their VMS potential, (a) Y vs. Zr/Y plot [74] displaying different rhyolite types FI, FII, FIIa, and FIIb that can be associated with VMS systems, (b) $\mathrm{Yb}_{\mathrm{n}}$ vs. $(\mathrm{La} / \mathrm{Yb})_{\mathrm{n}}$ plot $[13,74]$ displaying rhyolite types FI, FII, FIIIa, FIIIb, and FIV that can be associated with VMS systems, concentrations are normalized to chondrite using values of Nakamura [56], (c) Nb vs. Zr plot [83] highlighting barren (light grey) and ore-bearing (dark grey) VMS systems [15,16], (d) Y vs. Nb plot [84] showing the tectonic setting for felsic rocks with areas highlighting barren (light grey) and ore-bearing (dark grey) VMS systems $[15,16]$.

Mafic units that are often part of the host rock lithology in VMS systems (e.g., [85,86]) also play an important role in assessing the VMS potential of an area, since they provide important insight into the tectonic setting (e.g., $[15,16])$. The tholeiitic Group A basalts and the geochemical similar type I dykes have $\mathrm{Ti} / \mathrm{V}$ ratios of $18-25$, similar to back-arc basin basalts (BABB; Figure 21a). Transitional to calc-alkaline Group B basalts have a larger $\mathrm{Ti} / \mathrm{V}$ ratio of 20 to $>100$, and the majority of samples show BABB or midocean ridge basalt (MORB) affinity with a lesser number of samples being alkaline (Figure 21b). The variations in $\mathrm{Ti} / \mathrm{V}$ ratios can be explained by different parent rocks of MORB affinity. Group A basalts and type I dolerite show affinity to normal MORB (N MORB), whereas Group B rocks are more characteristic to have an enriched MORB (EMORB) parent, and the alkali basalts of type II relate to deep melting of ocean island basalt (OIB; Figure 21b). Based on Pearce's [87] $\mathrm{Nb} / \mathrm{Yb}$ versus $\mathrm{Th} / \mathrm{Yb}$ plot, the source regions for the different mafic rocks can be further determined. In Figure 21c, Group A basalts with type I dolerite and Group B rocks form 
different arrays that can be explained by assimilation of continental crust to either NMORB (Group A and type I) or EMORB (Group B). Increments of $<5$ up to $10 \%$ of UCC [88] explain the majority of mafic rocks present at the A6 Anomaly. Larger assimilation of UCC up to $30 \%$ is responsible for the remaining data (Figure 21c). The presence of two different source regions forming the mafic and intermediate lithological units with the exception of type II dolerite results in different geochemical parameters (Figure 11) and contrasting REE patterns (Figure 12). They show, in combination with Pearce's [87] Nb/Yb and Th/Yb plot (Figure 21c), that there is no genetic relationship between Group A and B lithological units. However, Group B andesites are related to Group B basalts and are most likely the product of larger UCC assimilation to EMORB (Figure 21c).
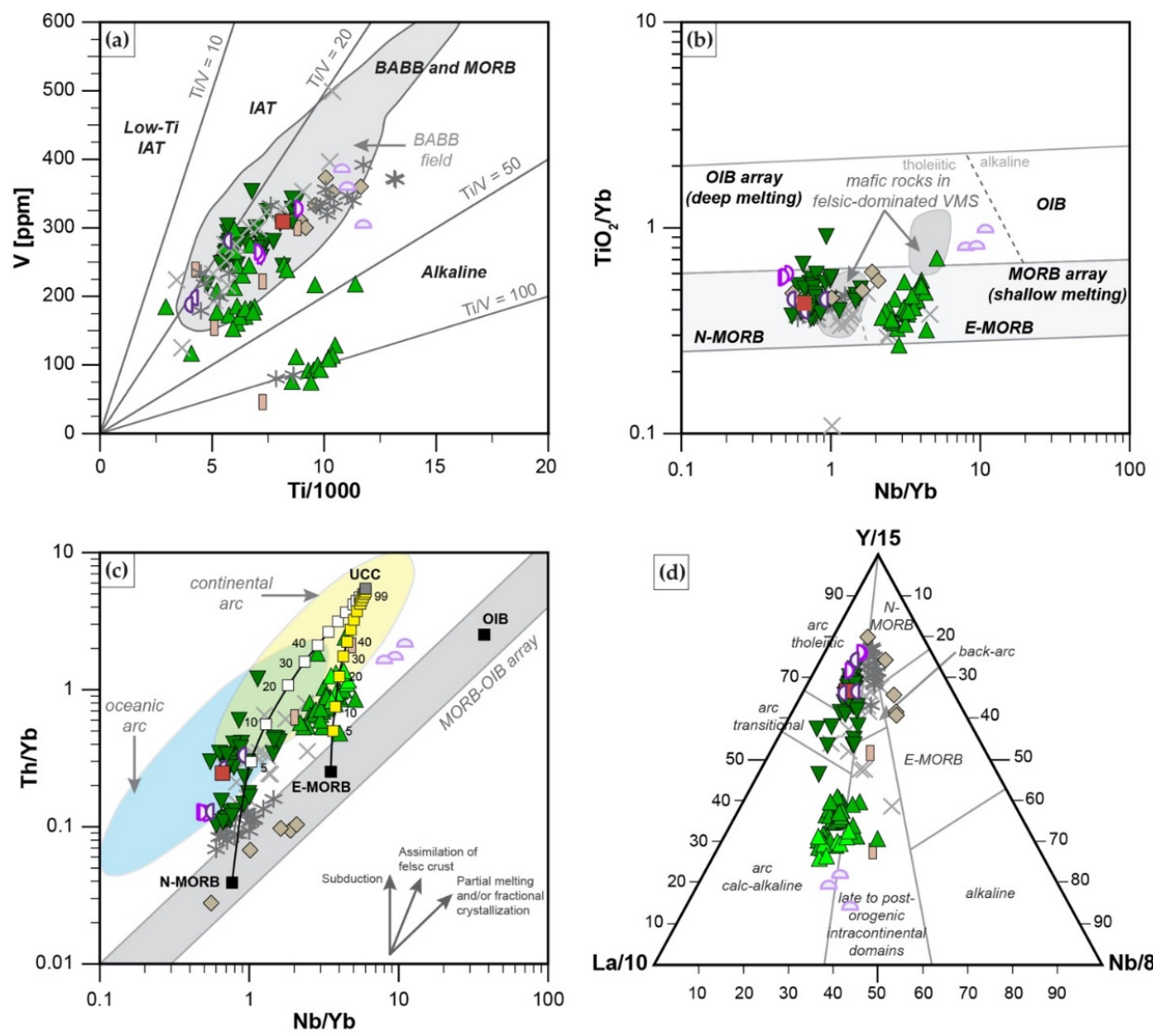

\begin{tabular}{|c|c|c|c|c|c|c|c|}
\hline \multicolumn{3}{|c|}{ A6 Anomaly mafic and intermediate units } & \multicolumn{3}{|c|}{ Eskay Creek mafic units } & \multirow{2}{*}{\multicolumn{2}{|c|}{$\begin{array}{c}\text { Eskay Rift } \\
\text { Basalt [10] }\end{array}$}} \\
\hline Flows and volcaniclastic rocks & & Dykes & Basalt (han & ging wall) & Andesite (footwall) & & \\
\hline $\boldsymbol{\nabla}$ Group $\mathrm{A}$ basalts & 0 & Dyke I-a & $\square$ This & study & [ $[40]$ & * & Group 1 (South) \\
\hline$\Delta$ Group B basalts & $D$ & Dyke I-b & $\diamond[40]$ & & & $x$ & Group 2 (North) \\
\hline \multirow[t]{2}{*}{$\triangle$ Group $B$ andesites } & - & Dyke II & & & & & \\
\hline & & Mixing tren & & & & & \\
\hline$\square$ N-MORB with UCC & $\square$ & E-MORB with UCC & $5,10 \ldots 99$ & $\begin{array}{l}\text { Incremer } \\
\text { or E-MO }\end{array}$ & $\begin{array}{l}\text { nixing from N-MORB } \\
\text { wards UCC in \% }\end{array}$ & & \\
\hline
\end{tabular}

Figure 21. Discrimination of mafic lithologies at A6 Anomaly and Eskay Creek, (a) Ti vs. V plot [89] showing tectonic setting of basalts and dolerites, field for back-arc basin basalts (BABB) highlighted in grey, (b) $\mathrm{Nb} / \mathrm{Yb}$ vs. $\mathrm{TiO}_{2} / \mathrm{Yb}$ biplot [90] discriminating between different melting sources for mafic rocks, (c) $\mathrm{Nb} / \mathrm{Yb}$ vs. Th/ $\mathrm{Yb}$ biplot [87] discriminating tectonic setting of mafic and intermediate rocks with mixing lines between N-MORB and UCC (white squares) and E-MORB and UCC (yellow squares), N-MORB, E-MORB and OIB composition from [58] and UCC composition from [88], (d) La-Yb$\mathrm{Nb}$ ternary plot [91] discriminating tectonic setting of mafic and intermediate rocks, See text for details. Note: Group A basalts from the A6 Anomaly and Group 1 basalts from the Eskay rift [10] are almost identical in their composition and hence overlap in particular in $(\mathbf{b}, \mathbf{d})$ resulting that data of Group 1 basalts are partially obscured by Group A basalts since focus is on lithologies of A6 Anomaly. Abbreviations: BABB—back-arc basin basalt, E-MORB-enriched mid-ocean ridge basalt, IAT—island arc tholeiite, $\mathrm{N}-\mathrm{MORB}$ — normal mid-ocean ridge basalt, OIB — ocean island basalt, UCC—upper continental crust. 
The geochemical similarity between Group A basalts and type I dolerite can be explained by formation in the same tectonic setting (i.e., back arc basin rift; Figure 21a,d) and hence the same time although no age date is available for these units yet. In contrast, type II dolerite are alkali basalts formed in intercontinental domains (Figure 21d) and hence are most likely related to Cenozoic magmatism [28].

Piercey $[15,16]$ showed that mafic rocks in mafic-hosted VMS deposits are shallow melted NMORB and of tholeiitic affinity (Figure 21b). However, this only applies to Group A basalts and type I dolerites at the A6 Anomaly whose spatial and temporal relationship to the altered felsic units is yet unclear (Figure 4). In contrast, Group B basalts, which occur predominantly above altered felsic rhyodacites and trachytes, are less likely to be affiliated with fertile VMS systems due to larger crustal contamination. Combining the results from assessing the felsic and mafic to intermediate units at the A6 Anomaly, they currently do not show strong ore-bearing VMS potential. Nevertheless, further exploration of the immediate and wider area with focus on geochemistry of felsic and mafic lithological units is needed to fully assess the area's VMS fertility.

\subsection{Comparison to Eskay Creek VMS Deposit and Tectonic Setting of A6 Anomaly}

The Eskay Creek deposit is an anomalous Au-rich VMS system hosted in bimodalfelsic lithologies of the Middle Jurassic Iskut River Formation, Upper Hazelton Group [2,11,12,17,40,41]. Due to its vicinity to the A6 Anomaly and similar stratigraphy and age, a comparison between the A6 Anomaly as potential VMS prospect and the Au-rich Eskay Creek VMS deposit is made here to further determine the tectonic setting of the A6 Anomaly which aids exploration in the area.

The maximum deposition age of the A6 Anomaly is based on U-Pb zircon ages of volcaniclastic and epiclastic units on the west and east side of the altered felsic units with $177 \pm 1.2$ and $176.4 \pm 0.94 \mathrm{Ma}$, respectively (Figure 4, Table 1) [45]. The altered felsic unit has a U-Pb zircon age of $172 \pm 1.7 \mathrm{Ma}$ [45] which is slightly younger than that of the Eskay rhyolite member with $175 \pm 2 \mathrm{Ma}$ [2,3]. Cutts et al. [3] analyzed zircons from various igneous lithological units east of the Eskay Creek deposit, determining the age of the Iskut River Formation to be in the region from $178.5 \pm 1.8$ to $173.3 \pm 1.8 \mathrm{Ma}$, which overlaps with the age dates at the A6 Anomaly.

The stratigraphy of the Eskay Creek deposit is described in detail in $[11,12,40,41]$ and briefly summarized here. The stratigraphy is characterized by footwall andesites and dacites that are overlain by a thin mudstone interval and the Eskay rhyolite member, which can be strongly altered to quartz-sericite-pyrite and hosted prominent stockworks (i.e., 109 zone, Pumphouse/Pathfinder). However, the economic valuable mineralization occurred on the interface of Eskay rhyolite with overlying mudstones (i.e., 'contact mudstone'; Figure 22) that hosted bedding-parallel, semimassive mineralization enriched in sulfosalts, As-Sb $\pm \mathrm{Hg}$-bearing phases and gold with lesser amount of base metal sulfides. Tholeiitic (pillow) basalts and sills alternate with less mineralized and unmineralized mudstones in the hanging wall. Felsic dykes (i.e., felsite) crosscut the footwall and thin mafic dykes crosscut both footwall and hanging wall. There are several similarities between the stratigraphy at the A6 Anomaly and at Eskay Creek (Figure 22) including: (1) felsic, altered flows with minor volcaniclastic rocks overlain by a volcano-sedimentary sequence; and (2) hanging wall mudstones alternating with basaltic flows and sills. However, the stratigraphy at the A6 Anomaly indicates a more dynamic environment above the altered felsic units, since turbiditic sequences consisting of submarine heterogeneous epiclastic units (conglomerate to siltstone) are common. 
A6 Anomaly (potential VMS prospect)

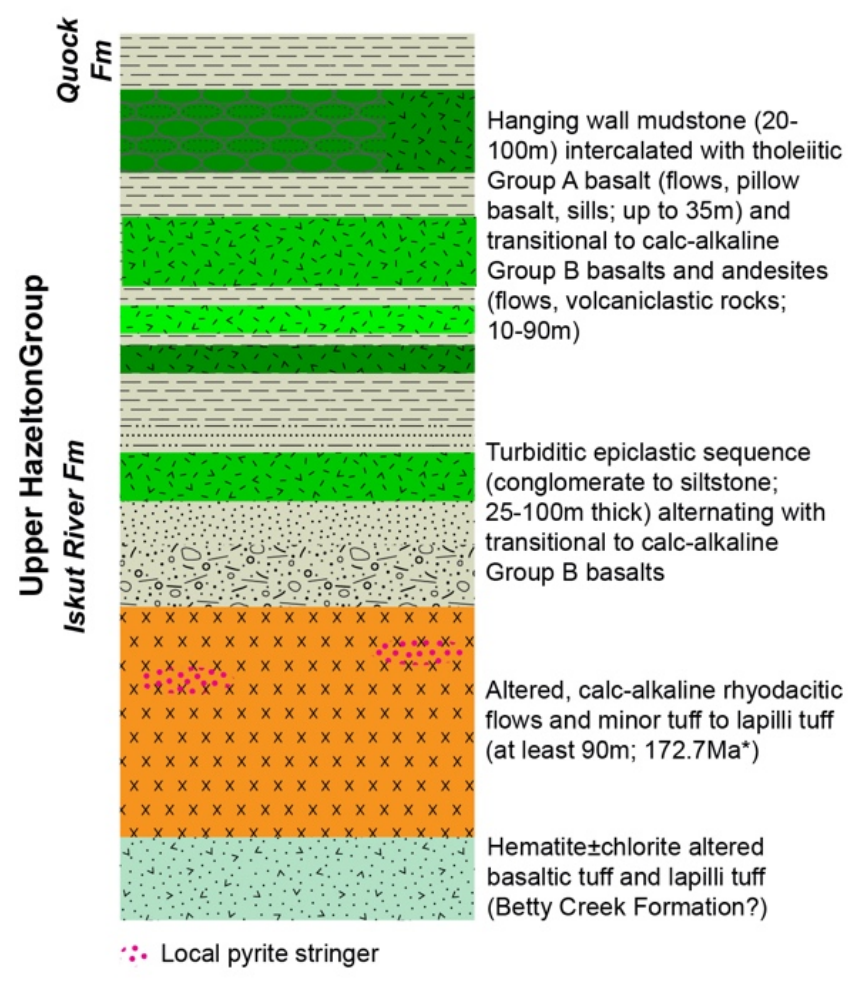

\section{Eskay Creek (anomalous Au-rich VMS deposit)}

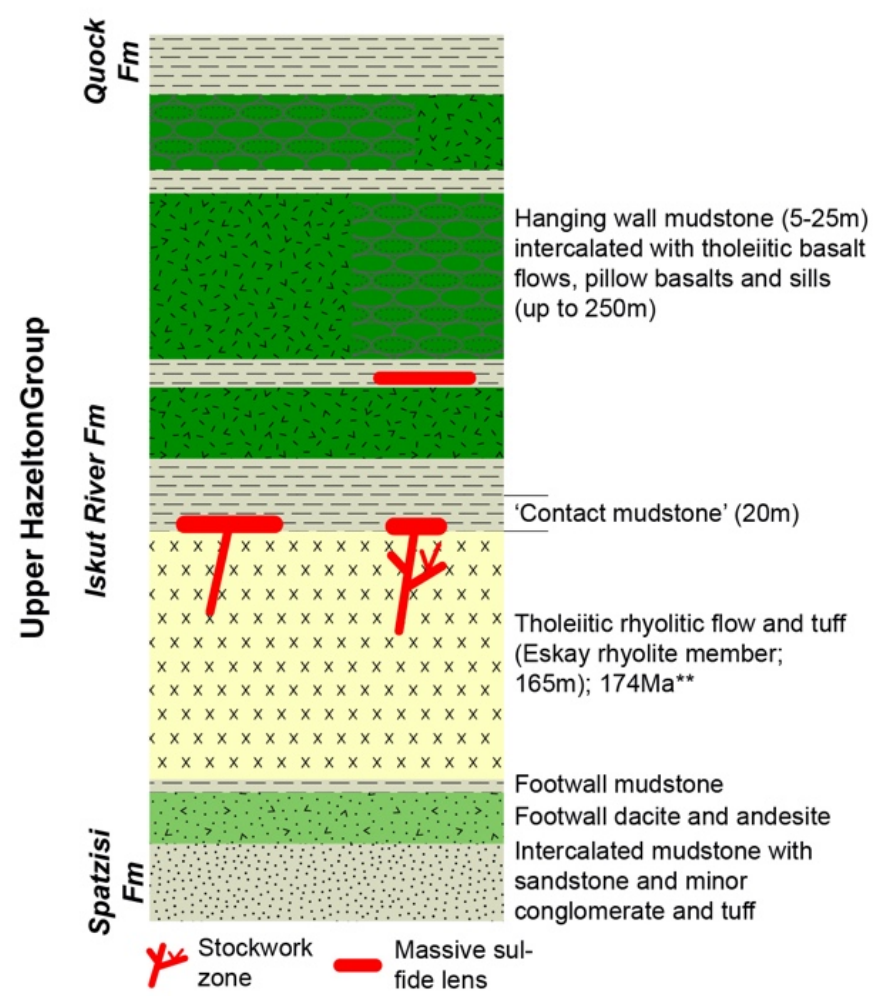

Figure 22. Comparison of Upper Hazelton Group stratigraphy at A6 Anomaly (left) and Eskay Creek deposit (right; modified after [41]; $[45], * *[2]$, sections not to scale.

Igneous lithologies at both locations indicate formation in a back arc basin setting (e.g., $[10,18,19,92])$. The Eskay Creek deposit is located in the Eskay rift, a ca. $300 \mathrm{~km}$ long and $50 \mathrm{~km}$ wide north-south zone of en echelon grabens active in the late-Early to Middle Jurassic and formed as result of collision between Stikinia and inboard terranes [8]. Lithologies formed within and along 12 sub-basins of the Eskay rift make up the Iskut River Formation present both at the A6 Anomaly and Eskay Creek VMS deposit (Figure 22). Despite the similar tectonic setting, the geochemistry of igneous units differs between A6 Anomaly and Eskay Creek (Table 5) indicating different processes with in the two subbasins. The felsic units at both locations show constant immobile element ratios (Figure 8) albeit at different slopes indicating different precursors. Moreover, both felsic units have different magmatic affinities (i.e., calc-alkaline vs. tholeiitic; Figure $7 \mathrm{~b}$ ) and different rhyolite affinities (i.e., FII vs. FIII; Figure 20a,b; [13,74]) due to different melting depth of the precursor. The tholeiitic Eskay Creek rhyolite member is most likely the result of partial melting at shallow depth $(<10 \mathrm{~km})$ of a plagioclase-bearing NMORB or EMORB (Figure 21b-d; $[13,40,74]$ ), which is in contrast to the felsic units with FII to minor FI affinity at the A6 Anomaly as discussed above. This indicates that the back-arc basin in which the felsic units at the A6 Anomaly formed was just opening and had a rather thick crust (Figure 23a). The Group B basalts overlying these felsic units confirm this environment, since their EMORB precursor assimilated crust resulting in a steep REE pattern and arc-like signature (Figures $12 \mathrm{~b}$ and $21 \mathrm{c}, \mathrm{d}$ ). 


\section{Formation of felsic units and Group B basalts/andesites}

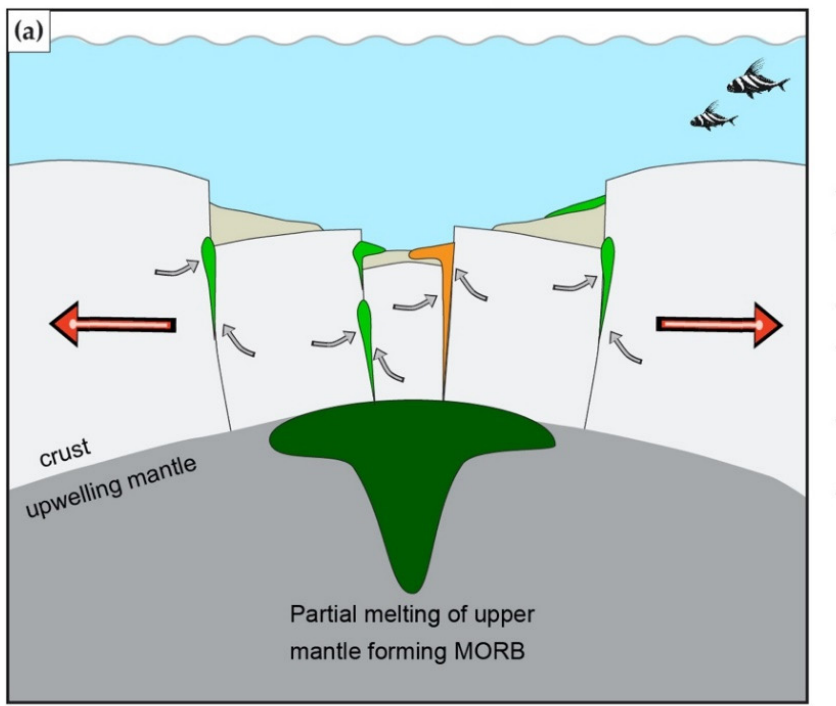

- Thinning of crust and upwelling of mantle

- Melting of upper mantle forming EMORB at depth of $10-15 \mathrm{~km}$

- During ascent of magma, assimilation of crust

- Formation of calc-alkaline FII rhyodacite and trachyte dome

- Formation of transitional to calc-alkaline Group $B$ lithologies

- Emplacement of turbiditic sequences during rift opening in marine sub-basins

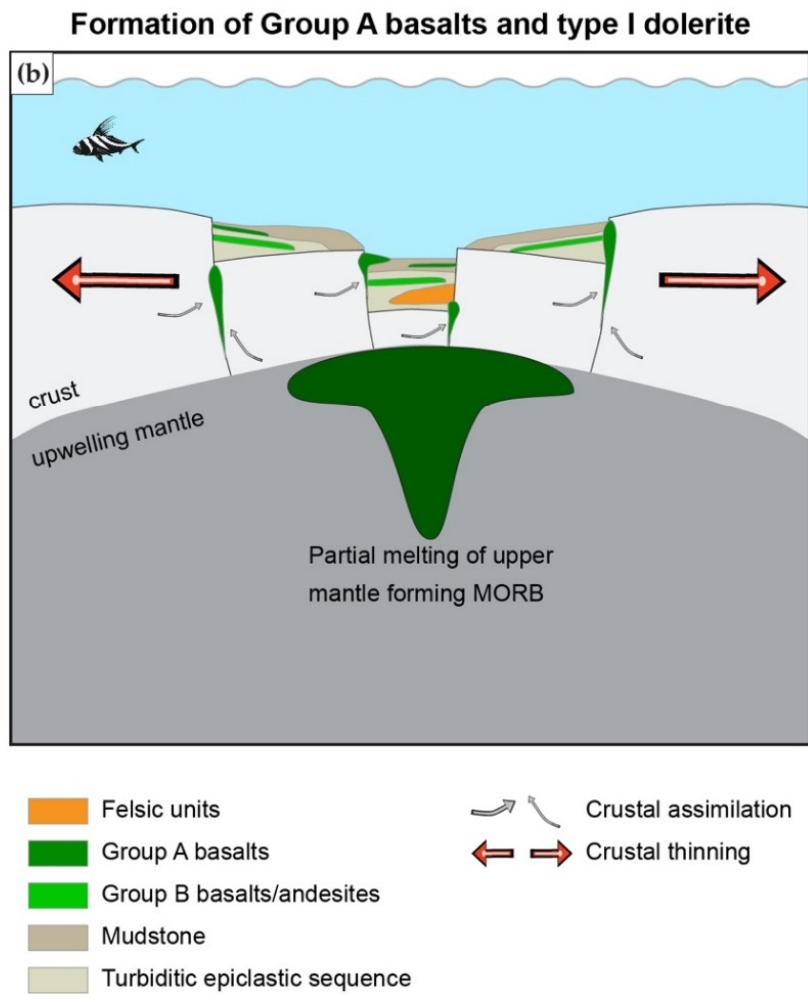

- Further thinning of crust and upwelling of mantle

- Melting of upper mantle forming NMORB at depth of $<10 \mathrm{~km}$

- During ascent of magma, minor assimilation of crust

- Formation of tholeiitic Group A basalts and type I dolerite (not shown)

- Deposition of mudstones in relative deep marine, quiet subbasins

Figure 23. Simplified genesis of the A6 Anomaly in an evolving back-arc basin rift, (a) Formation of altered felsic units and Group B mafic rocks due to deep partial melting of upwelling mantle producing EMORB, (b) Continuing thinning of back arc rifting resulting in shallower partial melting depth of upwelling mantle which is the source for Group A basalts and type I dykes; sketches not to scale.

In contrast, mafic rocks within the Eskay rift (i.e., Groups 1 and 2 basalts after Barresi et al. [10]; Figures 10-21) have MORB signatures with little (i.e., Group 1 basalt after [10]; Figure 21) to some (i.e., Group 2 basalt after [10]; Figure 21) crustal assimilation as result of shallow melting in an almost fully developed back-arc rift $[10,40]$. This setting developed as well at the A6 Anomaly due to continuous crustal thinning albeit after felsic units and Group B basalts formed (Figure 23b). The result of continuous thinning and mantle upwelling were Group A basalts and dyke I dolerite that occur in the hanging wall of the stratigraphy and cross-cut stratigraphy, respectively. However, no indication of felsic 
magmatism accompanying this stage of tholeiitic mafic igneous activity is recorded at the A6 Anomaly (i.e., subvolcanic intrusion, sills) which could have driven the heat engine of a VMS system as it occurred at Eskay Creek (i.e., Eskay rhyolite member). Hence, the evolving back-arc magmatism at the A6 Anomaly, despite its favoring tectonic setting for a VMS system (e.g., $[17,22,81,93,94])$, is currently lacking an effective and necessary heat engine, metal source, and felsic lithology formed at relatively shallow depth. The back-arc setting developed at the A6 Anomaly resembles more the northern Eskay rift than the southern part in which Anyox and Eskay Creek deposits formed. However, it is the first reported late-Early to Middle Jurassic tholeiitic basalts formed in a rift basin east of the Eskay rift and other, better developed sub-basins in the vicinity of the A6 Anomaly may be favorable for ore-bearing VMS deposits.

\subsection{Alteration}

Hydrothermal alteration assemblages reflect the pathways of hydrothermal fluids while circulating through the crust, which commonly intensifies towards mineralization, resulting in alteration zonation around the deposit (e.g., [95,96]). This alteration zoning is particularly prominent in VMS systems which can have a large alteration footprint that significantly exceeds the dimension of the ore body, and therefore, is commonly used in exploration to identify potential targets and vector towards massive sulfide lenses (e.g., [17,81,86,97-99]). Alteration assemblages provide information about hydrothermal fluid conditions (e.g., T, pH, redox state), fluid pathways, and spatial relation to a hydrothermally upwelling area. These parameters are determined here using quantitative (i.e., mass balance, isocon) analyses [100-104], geochemical (i.e., molar ratios, alteration indices; $[98,105,106])$, and compositional and geothermometric $[63,70,107-110]$ approaches.

\subsubsection{Isocon and Mass Balance Calculations}

There are different methods to quantify the physical (e.g., volume) and chemical (e.g., element gain/loss) changes caused by hydrothermal alteration, including the isocon method, mass balance, and immobile element approach; they all have their challenges (see [111] for discussion). However, these methods provide insight into fluid pathways, alteration intensity, and even metal source (e.g., [78]). Both the isocon method [100,101] and mass balance calculations [102-104] are applied here to quantify mass changes in the altered felsic units at the A6 Anomaly. Both approaches require a least altered precursor which is especially difficult to identify in poorly defined areas such as the A6 Anomaly, because felsic flows of the same geochemical composition but with no visible alteration were not observed. However, the altered felsic units are geochemically homogeneous indicating a common precursor (Figure 8), and hence, a least altered sample can be identified within this lithological unit. Here, three samples from BR-74 have been identified as least altered based on: (1) their $\mathrm{SiO}_{2}, \mathrm{TiO}_{2}$, and $\mathrm{Al}_{2} \mathrm{O}_{3}$ content similar to average rhyolite [111-113], (2) a loss on ignition (LOI) content $<2.9 \mathrm{wt} \%$, (3) an alteration index (Ishikawa, 1976) $<40$, and (4) a sericite index (i.e., $\left.\mathrm{K}_{2} \mathrm{O} /\left(\mathrm{K}_{2} \mathrm{O}+\mathrm{Na}_{2} \mathrm{O}\right)\right)<40$ indicating minimal loss in $\mathrm{Na}_{2} \mathrm{O}$ during hydrothermal activity. The average concentration of selected elements of the least altered rocks plotted against concentrations of altered rocks using the isocon method identify both volume and elemental loss/gain (Figure 24a). Immobile elements $\mathrm{Al}_{2} \mathrm{O}_{3}, \mathrm{TiO}_{2}, \mathrm{Nb}$ and $\mathrm{Zr}$ were used to define the isocon and elements were scaled [114] to better visualize changes. The scaling resulted in an isocon indicating a minimal volume loss (i.e., slope $\mathrm{m}=1.0909$; Figure 24a) relative to the average of the least altered samples. The calculated volume loss for altered felsic flows at the A6 Anomaly is rather minor compared to other VMS systems in which volume loss or gain commonly can exceed $20 \%$ highlighting the strong alteration of wall rocks in particular proximal to massive sulfide mineralization (e.g., [78,114]). Elemental gains (i.e., elements plot above isocon; Figure 24a) include Ba, $\mathrm{K}_{2} \mathrm{O}, \mathrm{Fe}_{2} \mathrm{O}_{3}$ and minor $\mathrm{MgO}$, whereas elements $\mathrm{Na}_{2} \mathrm{O}$ and lesser $\mathrm{SiO}_{2}$ and $\mathrm{CaO}$ were lost (i.e., plot below isocon). These gains and losses are further quantified using mass balance calculations $[103,104]$ in which $\mathrm{Al}_{2} \mathrm{O}_{3}$ was used as reference immobile element, since it is a 
major component and hence detected above detection limit in all samples and has the most constant ratios when plotted against other immobile elements.

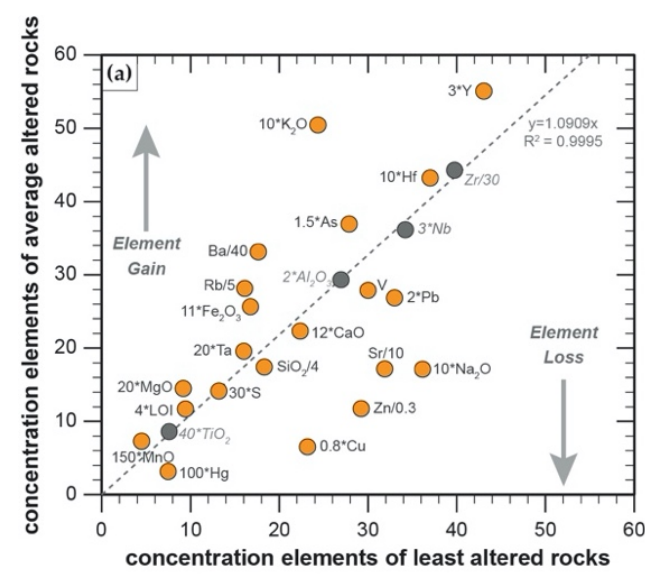

\begin{tabular}{|c|c|}
\hline \multicolumn{2}{|c|}{ Average least altered precursor $(n=3)$} \\
\hline $\mathrm{SiO}_{2}$ & $=72.02 \pm 2.25 \mathrm{wt} \%$ \\
\hline $\mathrm{Al}_{2} \mathrm{O}_{3}$ & $=13.76 \pm 0.50 w t \%$ \\
\hline $\mathrm{Fe}_{2} \mathrm{O}_{3}(\mathrm{t})$ & $=1.63 \pm 0.50 \mathrm{wt} \%$ \\
\hline $\mathrm{MgO}$ & $=0.50 \pm 0.08 w t \%$ \\
\hline $\mathrm{CaO}$ & $=2.32 \pm 0.82 \mathrm{wt} \%$ \\
\hline $\mathrm{Na}_{2} \mathrm{O}$ & $=3.44 \pm 0.51 \mathrm{wt} \%$ \\
\hline $\mathrm{K}_{2} \mathrm{O}$ & $=2.54 \pm 0.37 \mathrm{wt} \%$ \\
\hline LOI & $=2.85 \pm 0.88 \mathrm{wt} \%$ \\
\hline $\mathrm{s}$ & $=0.30 \pm 0.46 w t \%$ \\
\hline $\mathrm{BaO}$ & $=0.08 \pm 0.01 \mathrm{wt} \%$ \\
\hline
\end{tabular}
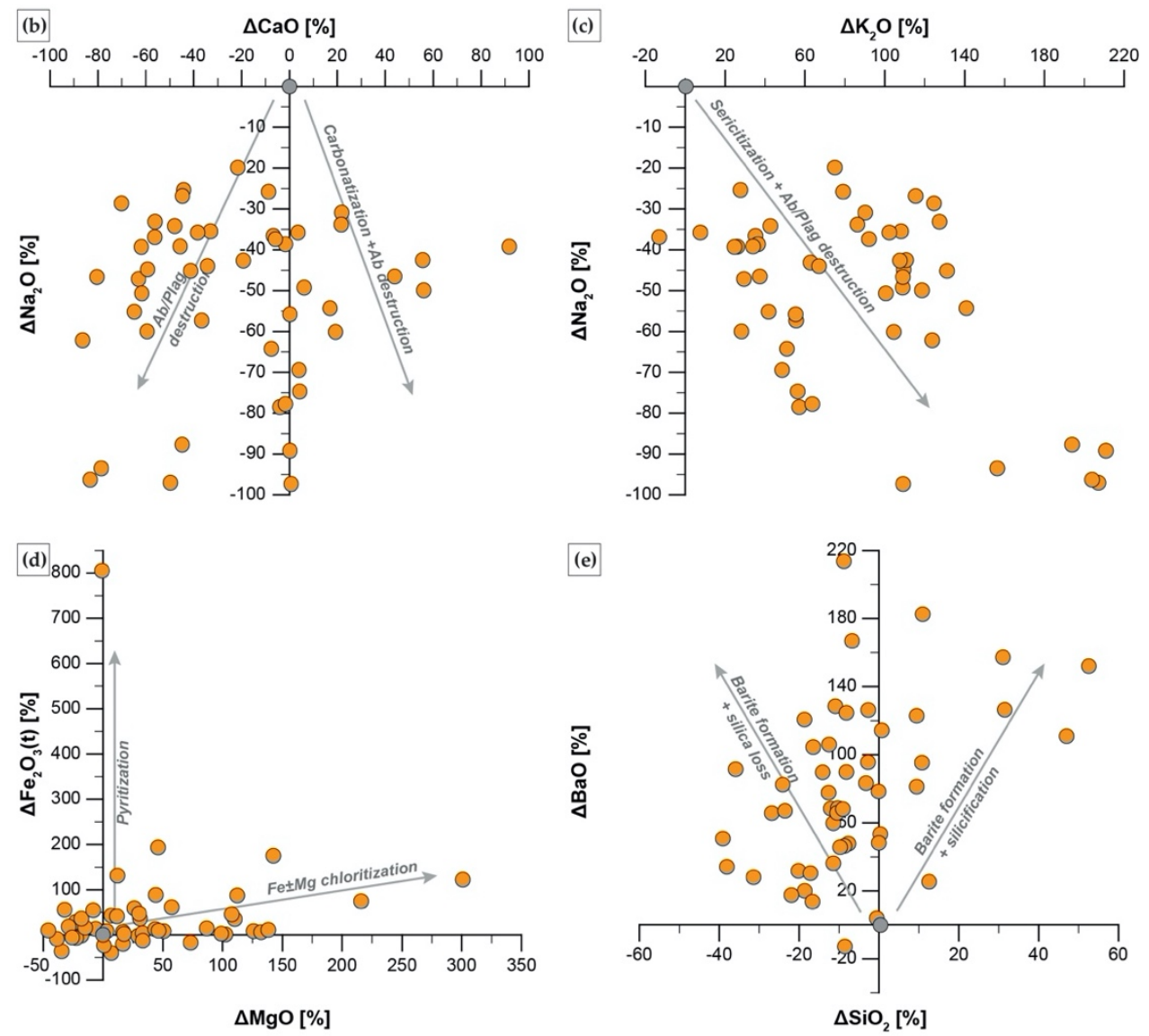

Figure 24. Mass balance calculation for altered felsic units from the A6 Anomaly. (a) Isocon diagram using the method of Grant [100,101] showing element gains and losses (orange circles) relative to immobile elements $\mathrm{Al}_{2} \mathrm{O}_{3}, \mathrm{TiO}_{2}, \mathrm{Nb}$, and $\mathrm{Zr}$ (dark grey circles) that describe the isocon (dashed line). Altered rocks underwent relative volume loss since isocon has a slope of $>1$. All elements are subjectively scaled using the method described by Mukherjee and Gupta [114] to better visualize gain/loss of elements, (b-e) Mass balance changes of altered felsic flows (orange circles) relative to an average of least altered sample (grey circle at point of origin) using the calculations of MacLean [103] and MacLean and Barrett [104]. All changes are given in $\%,\left(\right.$ b) $\Delta \mathrm{CaO}$ vs. $\Delta \mathrm{Na}_{2} \mathrm{O}$ displaying feldspar destruction and carbonatization, (c) $\Delta \mathrm{K}_{2} \mathrm{O}$ vs. $\Delta \mathrm{Na}_{2} \mathrm{O}$ displaying strong $\mathrm{K}$ gain due to sericitization at expense of albite and plagioclase destruction, (d) $\Delta \mathrm{MgO}_{\mathrm{vs}} \Delta \mathrm{Fe}_{2} \mathrm{O}_{3}(\mathrm{t})$ displaying $\mathrm{Fe}$ and $\mathrm{Mg}$ gain due to Fe-Mg-chloritization and pyritization (Fe gain), (e) $\Delta \mathrm{SiO}_{2} \mathrm{vs}$. $\Delta \mathrm{BaO}$ displaying silica gain or loss with formation of barite. Composition of average precursor $(n=3)$ with standard deviation is given in upper right for selected elements. See text for details. Abbreviations: Ab-albite, LOI—loss on ignition, Plag-plagioclase. 
Mass changes (Figure 24b-e) quantitatively confirm the alteration mineralogy of altered felsic units observed by microscopy and XRD analyses. Most prominent is loss in $\mathrm{Na}_{2} \mathrm{O}$ and, to a lesser extent, $\mathrm{CaO}$ (Figure $24 \mathrm{~b}$ ), and gain in $\mathrm{K}_{2} \mathrm{O}$ (Figure 24c) due to partial to complete albite and plagioclase destruction resulting in the formation of illite and minor $\mathrm{K}$-feldspar (Figures 13a-d and 14). Minor gain in $\mathrm{CaO}$ (Figure 24b) is attributed to late calcite veins cross-cutting early alteration (Figures $13 \mathrm{~h}, 14 \mathrm{e}, \mathrm{h}$ and 15$)$. Moderate gains in $\mathrm{Fe}, \mathrm{Mg}$, and $\mathrm{Ba}$ (Figure $24 \mathrm{~d}, \mathrm{e}$ ) are due to minor to trace $\mathrm{Fe} \pm \mathrm{Mg}$-chlorite, pyrite and barite accompanying the phyllic alteration assemblage. Loss and gain in $\mathrm{SiO}_{2}$ (Figure 24e) are the result of silicate destruction (e.g., feldspars) and quartz alteration, respectively.

The occurrence of barite, while not observed in the thin section due to the small grain size, is common in many low-temperature VMS deposits, and is commonly associated with distal alteration $[115,116]$. However, the limited number of drill holes and the absence of a (semi-) massive sulfide lens make it difficult to determine the spatial relation of the altered felsic units (i.e., alteration pipe proximal to sulfide lens vs. semi-conformable alteration zone distally around sulfide lens; e.g., $[17,117,118])$. The alteration in the felsic units represents footwall alteration, because overlying epiclastic rocks and basaltic flows in the hanging wall are relatively unaltered. Although sulfide mineralization has not been recognized, the alteration and mass change at the A6 Anomaly provides information on the fluid pathways. The horst-graben structure with steep dipping, N-S trending fault zones (Figure 4) flanking the altered felsic flows may represent syngenetic fluid pathways since alteration is most prominent adjacent to these faults. Additionally, zones of strong $\mathrm{Na}$ depletion $\left(<2 \mathrm{wt} \% \mathrm{Na}_{2} \mathrm{O}\right.$; Figure 4$)$ are related to changes in lithology (coherent flows to overlying volcaniclastic rocks) and more commonly to zones of brittle deformation which both provide increased fluid permeability and hence fluid upwelling.

\subsubsection{Alteration Geochemistry and Geothermometry}

The alteration boxplot (Figure 25a) defines the degree of sericitization, chloritization, pyritization and carbonatization of altered felsic to mafic rocks in VMS systems using two indices: (1) alteration index AI [106] defining sericitization and (2) chlorite-carbonate-pyrite index CCPI [98] characterizing degree of chloritization, carbonatization and pyritization (Figure 25a). The altered felsic units of the A6 Anomaly have a low CCPI ( $<40$ for most samples) and an AI varying between $<35$ to $>90$ (Figure 25a) displaying no significant chlorite-carbonate and/or sulfide mineralization at varying phyllic (sericite) alteration, which supports the mineralogical observations. Additionally, the lack of consistent and moderate chlorite alteration is both a function of felsic host rock lithology and fluid temperatures not exceeding $300{ }^{\circ} \mathrm{C}$ that could have otherwise transformed sericite into chlorite (e.g., $[95,98,105,111])$. Despite the rather moderate degree of phyllic alteration in the felsic units, the main process of sericitization (i.e., formation of white mica or clays due to the destruction of feldspar) affects the complete unit, albeit to different degrees (Figure 25b). Feldspar destruction at the A6 Anomaly occurred via three processes (Figure 25b,c): (i) albite destruction resulting in $\mathrm{Na}$ loss and $\mathrm{K}$ gain and hence illite formation; (ii) plagioclase destruction resulting in $\mathrm{Na}$ and $\mathrm{Ca}$ loss and $\mathrm{K}$ gain and hence $\mathrm{K}$-feldspar formation; and (iii) K-feldspar destruction resulting in $\mathrm{K}$ loss and illite and quartz formation. Although the first two processes are most prominent (Figures 14, 15 and 24b,c), the last, albeit minor process has been observed as well (Figure 13d). 

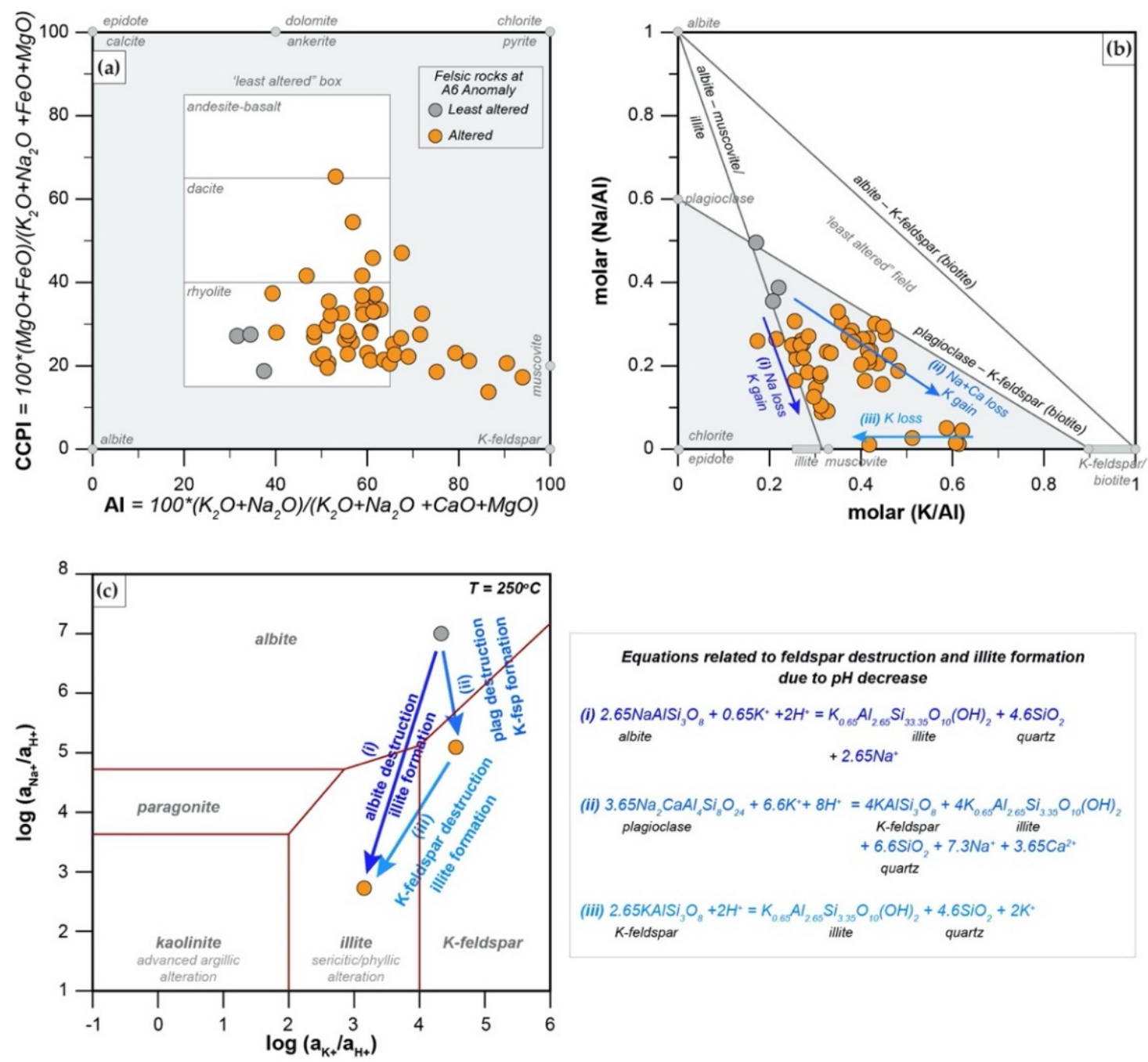

Figure 25. Quantification of processes related to K-Na \pm Ca mass changes in altered felsic units of the A6 Anomaly (orange circles), (a) Alteration box plot, AI vs. CCPI [98], (b) molar ratios of mobile versus immobile element depicting K/Al vs. $\mathrm{Na} / \mathrm{Al}[105]),(\mathbf{c})\left(\mathrm{K}^{+} / \mathrm{H}^{+}\right)$activity- $\left(\mathrm{Na}^{+} / \mathrm{H}^{+}\right)$activity diagram displaying the processes related to feldspar destruction in the felsic units of the A6 Anomaly at $250{ }^{\circ} \mathrm{C}$, phase diagram modified after [119] with thermodynamic data of [120], equations depicting processes (i) to (iii) highlighted in $(\mathbf{b}, \mathbf{c})$ are given in the lower right. See text for details.

Due to its common occurrence, the hydrothermal fluid conditions (e.g., T, $\mathrm{pH}$, redox) responsible for sericitization, and hence, phyllic alteration, are clearly identified; they require a relatively low temperature $\left(<300^{\circ} \mathrm{C}\right)$ and mildly acidic, oxidized hydrothermal fluid (equations in Figure 25; $[95,96,98,121-123])$. Based on the observations in the altered felsic units (i.e., moderate alteration degree; phyllic alteration assemblage; mass gain/loss in particular of $\mathrm{Na}$ and $\mathrm{Ca}$ ) these conditions were responsible for the alteration assemblage in the felsic units as well. Additionally, variations in illite composition show that sericitization of feldspars occurred at increasing temperatures since both I/S and illite close to endmember composition are present (Figure 18). This process of illitization (i.e., sequential formation of illite commonly from smectite with increasing temperature; $[66,107,124,125])$ is well observed in hydrothermal systems including geothermal fields [126], Zn-Pb hosted Irish-type deposits [127], VMS and seafloor massive sulfide deposits (e.g., [128,129]), and porphyry deposits [130]) and is a function of temperature. Illite/smectite is stable at temperatures of $<200-230{ }^{\circ} \mathrm{C}[119,124]$, whereas endmember illite stability is commonly achieved at temperatures of 230 to $360{ }^{\circ} \mathrm{C}[63,65,107,119,125]$. However, muscovite is not present in the altered felsic units indicating that illite formed at temperatures $<275^{\circ} \mathrm{C}$, since muscovite is unstable in this temperature range [65]. Fluid temperature was further determined by applying 
several geothermometers including: (1) K-Mg-Fe composition of illite [70] and (2) oxygen isotope geothermometry involving $\delta^{18} \mathrm{O}_{\text {illite-water }}$ and $\delta^{18} \mathrm{O}_{\text {quartz-water. Geothermometry }}$ using illite composition is debated since results vary even within the same alteration assemblage within a district [122]. However, Battaglia [70] showed that using K-Fe-Mg composition in illite can result in valid temperatures of phyllic alteration (Equation (5)):

$$
\mathrm{T}\left[{ }^{\circ} \mathrm{C}\right]=267.95 \mathrm{x}+31.50, \mathrm{x}=\mathrm{K}+|\mathrm{Fe}-\mathrm{Mg}|
$$

Using Equation (5) for all successful illite analyses resulted in an average temperature of $225 \pm 16^{\circ} \mathrm{C}$ (Table 3). However, there is a temperature gradient with fluid temperatures decreasing downwards from $\approx 230-240{ }^{\circ} \mathrm{C}$ to $\approx 220-200{ }^{\circ} \mathrm{C}$ (Figure 26; Supplementary Materials Table S7). Lower fluid temperatures $\left(200-220^{\circ} \mathrm{C}\right)$ coincide with I/S composition (e.g K $=0.50-0.69 \mathrm{apfu}$ ), whereas higher temperatures $\left(230-240^{\circ} \mathrm{C}\right)$ relate to illite composition close to endmember illite $(\mathrm{K}=0.69-0.80 \mathrm{apfu})$. Although temperature commonly increases downwards in VMS systems (e.g., [81,86,118]), an inverse temperature gradient has also been observed locally on the modern Tinakula seafloor massive sulfide deposit in the Solomon Islands [128]. The inverse temperature profile at the A6 Anomaly is related to zones of increased brittle deformation with abundant fractures and quartz veins that allowed for larger lateral fluid flow due to higher permeability and was not caused by lithological changes (i.e., coherent flows vs. overlying volcaniclastic rocks). Despite varying temperatures with depth, the alteration assemblage does not change significantly which contrasts with other hydrothermal systems (e.g., $[128,129])$ and displays the homogeneity of alteration assemblage over a relatively large area (ca. $0.5 \mathrm{~km}^{2}$ ). Although highest fluid temperatures coincide with areas of strong Na depletion, K enrichment (e.g., sericitization and illitization) and high AI, sulfide and base metal content rather correlate with lower temperatures and less alteration intensity (Figure 26).

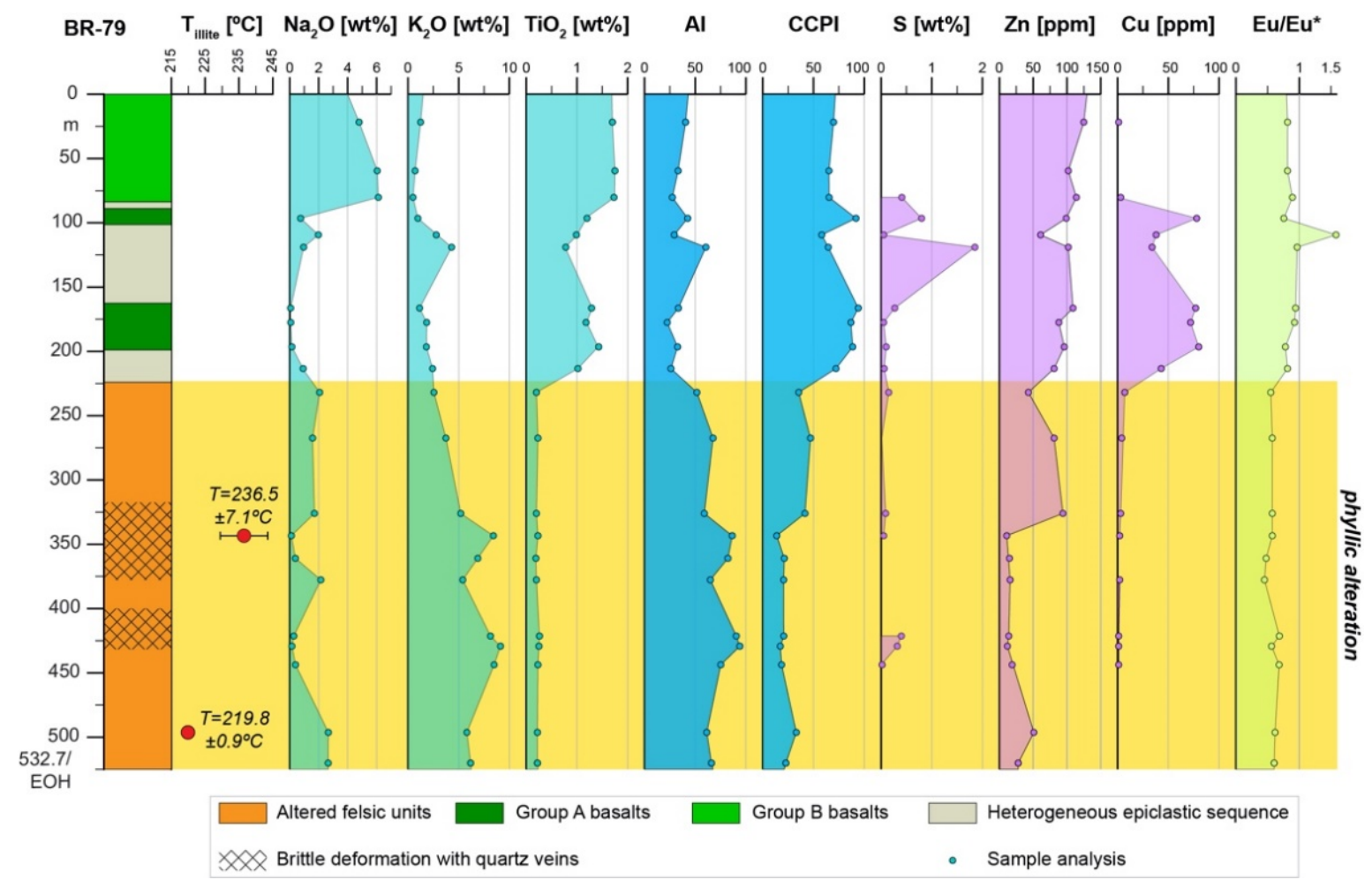

Figure 26. Vertical changes in major and minor element composition $\left(\mathrm{Na}_{2} \mathrm{O}, \mathrm{K}_{2} \mathrm{O}, \mathrm{TiO}_{2}\right)$, alteration intensity (AI, CCPI), $\mathrm{S}$ and base metal content $(\mathrm{Cu}, \mathrm{Zn})$, and Eu anomaly $\left(\mathrm{Eu} / \mathrm{Eu}^{*}\right)$ in lithologies at the A6 Anomaly based on drillhole BR-79, Note that phyllic alteration (yellow area) in altered felsic units is strongest at higher $\mathrm{T}$ that correlate with brittle deformation, $\mathrm{T}_{\text {illite }}$ is based on calculations using illite composition (Equation (6); [70]). 
Oxygen geothermometry is applied to confirm the temperatures of the illite geothermometer. Since neighboring quartz-illite pairs are analyzed, (Figure 19c,d), isotopic equilibrium is tested using the method described in Gregory and Criss [131] and Gregory et al. [132]. If isotopic equilibrium is established, $\delta^{18} \mathrm{O}$ composition of neighboring quartzillite pairs aligns in a positive linear array with a slope close to 1 , with strong correlation factor $R^{2}$ and an intercept of 0 . The slope is used to calculate the equilibrium temperature since it correlates to Equation (6):

$$
\delta^{18} \mathrm{O}_{\mathrm{qz}}-\delta^{18} \mathrm{O}_{\mathrm{ill}}=\Delta^{18} \mathrm{O}_{\mathrm{qz}-\mathrm{ill}} \approx 1000 \ln \alpha_{\mathrm{qz}-\mathrm{ill}}=\mathrm{A} \frac{10^{6}}{\mathrm{~T}^{2}}+\mathrm{B} \frac{10^{3}}{\mathrm{~T}}+\mathrm{C}
$$

where $\delta^{18} \mathrm{O}_{\mathrm{qz}, \text { ill }}$ is the oxygen isotope composition of quartz and illite, respectively; $\Delta^{18} \mathrm{O}_{\mathrm{qz}-\mathrm{ill}}$ is the difference in isotopic composition of neighboring quartz and illite; $\alpha_{\text {qz-ill }}$ is the fractionation factor between quartz and illite; $\mathrm{A}, \mathrm{B}$, and $\mathrm{C}$ are constants; and $\mathrm{T}$ is temperature in Kelvin. Isotherms ranging between 160 to $700{ }^{\circ} \mathrm{C}$ were calculated using $0.95,0$ and 0.9 for constants $A, B$, and $C$, respectively, at $\mathrm{T}=160-270{ }^{\circ} \mathrm{C}$ [133] and $0.735,0.912$ and 0 for constants $\mathrm{A}, \mathrm{B}$, and $\mathrm{C}$, respectively, at $\mathrm{T}=300-700{ }^{\circ} \mathrm{C}$ [110]. However, quartz-illite pairs from the felsic units neither show a positive slope, strong correlation or align parallel to an isotherm (Figure 27a), indicating isotopic disequilibrium between both phases. Geothermometric calculations than involved hydrothermal fluids and each phase, since isotopic equilibrium between hydrothermal fluid and illite or quartz in a fully open system can be assumed due to a constant evolved seawater input $[109,131,134]$. Fluid temperatures were calculated assuming $\delta^{18} \mathrm{O}_{\mathrm{H}_{2} \mathrm{O}}$ composition between 0.5 to $2.3 \%$ based on the data of hydrothermal fluids from active vents [135] and applying Equation (7) [109] and Equation (8) [108] for illite and quartz, respectively:

$$
\begin{gathered}
\delta^{18} \mathrm{O}_{\mathrm{ill}}-\delta^{18} \mathrm{O}_{\mathrm{H}_{2} \mathrm{O}}=\Delta^{18} \mathrm{O}_{\mathrm{ill}-\mathrm{H}_{2} \mathrm{O}} \approx 1000 \ln \alpha_{\mathrm{ill}-\mathrm{H}_{2} \mathrm{O}}=2.39 \times \frac{10^{6}}{\mathrm{~T}^{2}}-3.76 \\
\delta^{18} \mathrm{O}_{\mathrm{qz}}-\delta^{18} \mathrm{O}_{\mathrm{H}_{2} \mathrm{O}}=\Delta^{18} \mathrm{O}_{\mathrm{qz}-\mathrm{H}_{2} \mathrm{O}} \approx 1000 \ln \alpha_{\mathrm{qz}-\mathrm{H}_{2} \mathrm{O}}=4.28 \times \frac{10^{6}}{\mathrm{~T}^{2}}-3.5 \times \frac{10^{3}}{\mathrm{~T}}
\end{gathered}
$$

The results are shown in Figure 27b. Based on variations in illite composition (i.e., $\mathrm{I} / \mathrm{S}$ and close to illite endmember) and their stability at $\mathrm{T}=200-360^{\circ} \mathrm{C}$ (e.g., $\left.[63,65,119]\right)$, $\delta^{18} \mathrm{O}_{\mathrm{H}_{2} \mathrm{O}}$ composition of evolved seawater was most likely closer to $4 \%$ (Figure 27b). This 'heavier' oxygen composition in hydrothermal fluids has been observed in some VMSforming systems including Kuroko deposits $\left(\delta^{18} \mathrm{O}_{\mathrm{H}_{2} \mathrm{O}}=6-10 \%\right.$; $\left.[136,137]\right)$, Bathhurst mining Camp $\left(\delta^{18} \mathrm{O}_{\mathrm{H}_{2} \mathrm{O}}=4 \%\right.$; [138]) and seafloor massive sulfide systems $\left(\delta^{18} \mathrm{O}_{\mathrm{H}_{2} \mathrm{O}} \approx 5 \%\right.$; [128]). However, it is unclear if boiling, a magmatic component or both processes contributed to higher $\delta^{18} \mathrm{O}_{\mathrm{H}_{2} \mathrm{O}}$ composition at the A6 Anomaly based on the current data (e.g., unknown water depth; lack of bladed alteration phases). The hydrothermal fluid temperatures at the A6 Anomaly based on illite composition, illite geothermometry, and oxygen geothermometry ranged between $200-250^{\circ} \mathrm{C}$, and are higher than fluid temperatures responsible for the mineralization at Eskay Creek [37] (Figure 27b). 

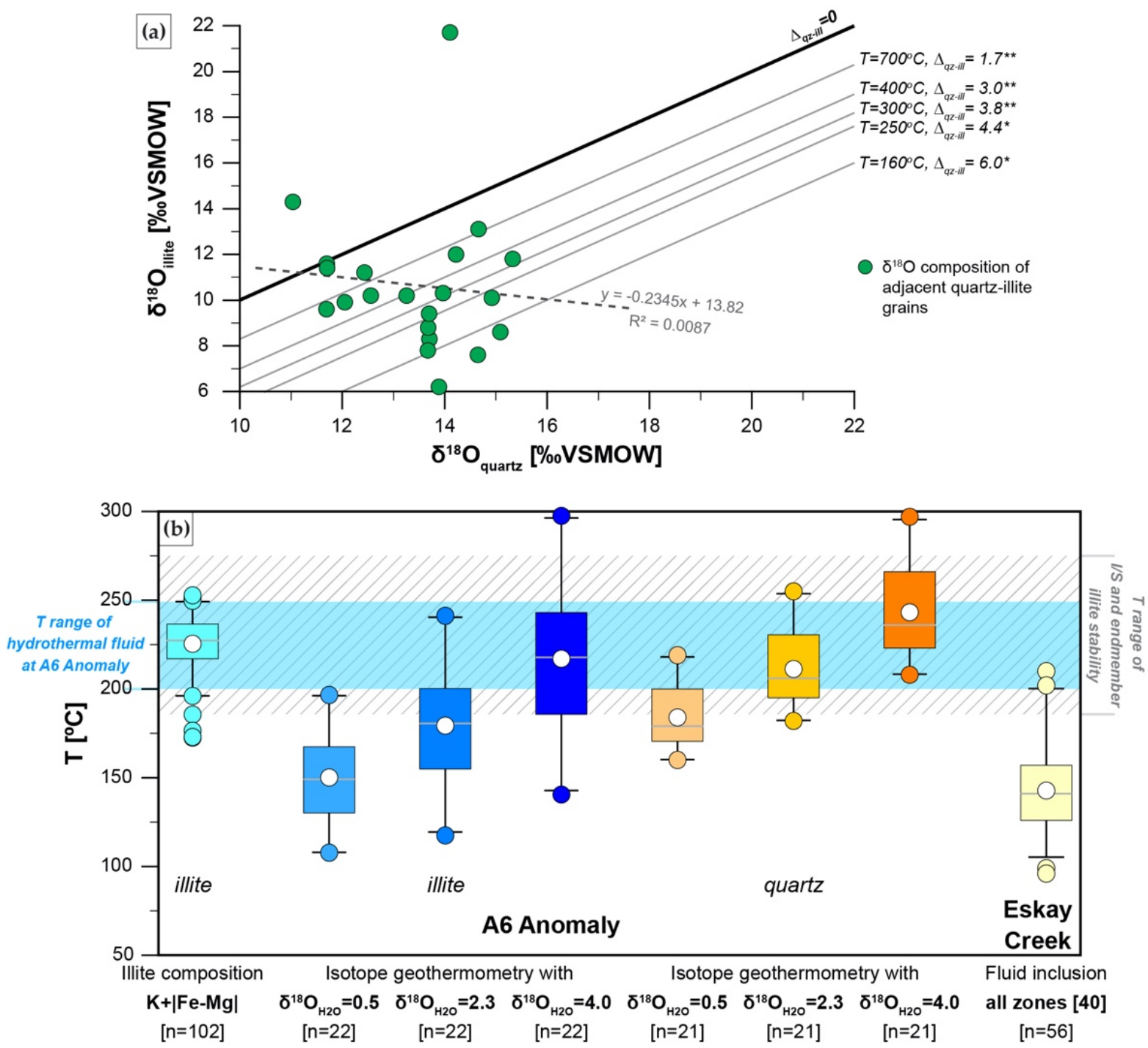

Figure 27. (a) $\delta-\delta$ plot of neighboring quartz and illite grains displaying that quartz and illite are not in isotopic equilibrium, since data points are widely scattered, very poorly correlated (dashed line, $R^{2}=0.0087$ ), do not align parallel to isotherms of 160 to $700{ }^{\circ} \mathrm{C}$, or even show reverse fractionation (above thick black line with $\Delta_{\mathrm{qz}-\mathrm{ill}}=0$ ) that is not observed in nature. Isotherms were calculated using: ${ }^{*} \Delta_{\mathrm{qz}-\mathrm{ill}}=\delta^{18} \mathrm{O}_{\mathrm{qz}}-\delta^{18} \mathrm{O}_{\mathrm{ill}} \approx 1000 \mathrm{lna}_{\mathrm{qz}-\mathrm{ill}}=0.95 \times 10^{6} / \mathrm{T}^{2}+0.9$ for $\mathrm{T}=160-270{ }^{\circ} \mathrm{C}[133]$ and ${ }^{* *} \Delta_{\mathrm{qz}-\text { ill }}=\delta^{18} \mathrm{O}_{\mathrm{qz}}-\delta^{18} \mathrm{O}_{\mathrm{ill}} \approx 1000 \operatorname{lna}_{\mathrm{qz}-\text { ill }}=0.735 \times 10^{6} / \mathrm{T}^{2}+0.912 \times 10^{3} / \mathrm{T}$ for $\mathrm{T}=200-900{ }^{\circ} \mathrm{C}$ [110], (b) Percentile box-whisker plot of calculated temperatures of the hydrothermal fluid using illite composition [58], isotope geothermometry for illite- $\mathrm{H}_{2} \mathrm{O}$ and quartz- $\mathrm{H}_{2} \mathrm{O}$ pairs after Sheppard and Gilg [109] and Sharp et al. [108], respectively, with assumed $\delta^{18} \mathrm{O}_{\mathrm{H}_{2} \mathrm{O}}=0.5,2.3$ and $4 \%$, and homogenization temperatures of fluid inclusions in quartz and sphalerite from Eskay Creek [37], light blue horizontal bar indicates temperature range of hydrothermal fluid responsible for alteration at the A6 Anomaly and shaded area is stability of I/S and endmember illite without the presence of muscovite, legend as in Figure 17. See text for details and calculations are summarized in Supplementary Materials Table S7.

Physico-chemical hydrothermal fluid conditions (i.e., $\mathrm{T}=200-250{ }^{\circ} \mathrm{C}$; mildly acid, oxidized) causing phyllic alteration in felsic units at the A6 Anomaly are common for $\mathrm{Zn} \pm \mathrm{Pb}$ VMS hosted within (bimodal-)felsic lithologies $[17,85,86,139]$. However, the lack of mineralization in the studied felsic altered units indicates either an insufficient metal source (e.g., altered units itself) or a yet undiscovered massive sulfide lens which would be rather distal to the studied drill holes. Although quartz-illite alteration can occur rather proximal to and in hydrothermal upwelling zones beneath ore lens(es) (e.g., $[128,140])$, the relative homogeneity of alteration assemblage in the felsic units over several hundred meters distance, the low temperature gradient laterally and horizontally, and the lack 
of pervasive sulfide stringers instead indicate distal alteration or alteration in a barren VMS system.

\section{Conclusions}

In this study, the stratigraphy and lithogeochemistry of igneous rocks, and the alteration assemblage of felsic units including the mineral composition and chemistry of the A6 Anomaly, were investigated to determine the VMS potential, alteration mineralogy, and hydrothermal fluid conditions, and provide a spatial context of the observed alterations. The following conclusions were drawn:

- Stratigraphy at the A6 Anomaly is comprised of altered felsic rhyodacites to trachytes that are overlain by a fining upward volcano-sedimentary sequence consisting of heterogeneous turbiditic sequence and mafic to intermediate volcanic rocks. This stratigraphy has late-Early to Middle Jurassic age (177-172.7 Ma) and is assigned here to the Iskut River Formation of the Upper Hazelton Group.

- Rhyodacites and trachytes have a calc-alkaline affinity and represent FII to minor FI rhyolites with $\mathrm{Zr}<200 \mathrm{ppm}$, and a weakly decreasing REE pattern that has a weakly negative Eu anomaly. These units were formed by partial melting of an amphiboleplagioclase precursor at a melting depth of $10-15 \mathrm{~km}$ in an evolving back-basin.

- Mafic units, which are distinguished into Group A basalts (tholeiitic, $\mathrm{Nb} / \mathrm{Yb}<1.6$; slightly decreasing REE pattern) and Group B basalts and andesites (transitional to calc-alkaline, $\mathrm{Nb} / \mathrm{Yb}>2.2$; strongly decreasing REE pattern), represent MORB with varying degrees of crust assimilation. Group B basalts, which occur spatially in the hanging wall of altered felsic units, are formed in a similar back-arc setting to those of rhyodacites to trachytes. In contrast, Group A basalts which occur predominantly in the upper part of the stratigraphy formed when the evolving back arc basin thinned due to extension, resulting in less crustal contamination compared to Group B rocks; this indicates the presence of a rift basin east of the main Eskay rift.

- Felsic and mafic units at the A6 Anomaly are ambiguous in their potential to host an ore-bearing VMS deposit, since they have characteristics of both barren VMS systems (e.g., absence of subvolcanic intrusion that provide heat and metals; felsic units with geochemistry common in VMS barren systems and low metal content; lack of distinct sulfide stringers common in stockwork zones beneath massive sulfide lenses) and ore-bearing VMS systems (e.g., association with shallow melting mafic units such as Group A basalts; pre-dominant FII affinity; formation in evolving back-arc rift common for VMS formation). Hence, further exploration in the area should focus on identifying a shallow subvolcanic tholeiitic felsic intrusion that could have provided heat and base metals, and on further identifying the stratigraphy and geochemistry of igneous units.

- The alteration assemblage in the altered felsic units is laterally and vertically homogeneous, defined by phyllic alteration with quartz-illite-K-feldspar \pm chlorite \pm pyrite \pm calcite \pm barite \pm rutile. Illite is of I/S and almost endmember illite composition and formed from feldspar (albite, plagioclase, K-feldspar) destruction by mildly acidic $(\mathrm{pH}=4-5.5)$, oxidized fluids at temperatures of $200-250{ }^{\circ} \mathrm{C}$. The alteration represents distal footwall alteration, presumably in a semiconformable alteration zone, and lacks significant sulfide stringers and metal enrichment. Hydrothermal fluids, despite favorable fluid conditions, in particular for $\mathrm{Zn} \pm \mathrm{Pb} \pm \mathrm{Ag}$ transport, were relatively metal barren.

Supplementary Materials: The following supplementary materials are available online at https: / / www.mdpi.com/article/10.3390/min11080867/s1, Table S1a: Diamond drill hole information, coordinates in UTM9, Table S1b: Sample information for whole rock lithogeochemistry, Table S1c: Sample information for mineralogy and in situ geochemistry of altered flows, Table S2a: Methods used by ALS to analyze major, minor and trace elements. Table S2b: Detection limits based on ALS methods for analyzed elements and different methods, Table S2c: Precision (RSD) and accuracy 
(RD) for reference materials (RMs) used for major, minor and trace element lithogeochemistry, Table S2c: Precision (RSD) and accuracy (RD) for reference materials (RMs) used for major, minor and trace element lithogeochemistry, Table S3: Results of SIMS measurement on in-house muscovite and quartz RMs, Table S4: Results of whole rock lithogeochemistry and calculated parameters, Table S5: Mineralogical composition altered felsic flows from XRD analyses, Figure S1. Mineralogical composition of altered felsic flows, Table S6a: K-feldspar composition with calculated mineral formula in altered felsic flows, Table S6b: Illite composition with calculated mineral formula in altered felsic flows, Table S6c: Pyrite composition with calculated mineral formula in altered felsic flows, Table S7: Calculated fluid temperature using illite composition for all drill holes.

Author Contributions: Conceptualization, H.G., S.M.B., R.S., S.W. and K.M.; methodology, S.M.B., G.J., S.W. and K.M.; software, S.M.B.; validation, S.M.B. and G.J.; formal analysis, G.J. and S.M.B.; investigation, S.M.B. and G.J.; resources, S.W., C.A. and K.M.; data curation, G.J. and S.M.B.; writingoriginal draft preparation, S.M.B.; writing-review and editing, all authors; visualization, S.M.B.; supervision, S.M.B.; project administration, S.M.B., S.W., C.A. and K.M.; funding acquisition, H.G. and S.M.B. All authors have read and agreed to the published version of the manuscript.

Funding: This research was funded by Pretivm Resources Inc. (Vancouver, BC) and Mineral Exploration Research Centre (Laurentian University) to SMB and by Pretivm Resource Inc. supporting analytical work for GJ's BSc honors thesis.

Data Availability Statement: All data collected for this research are published in this paper and the Supplementary File.

Acknowledgments: SMB thanks the geological and technical staff at Pretivm Resources Inc for their support in field and during core logging. Skeena Resources is thanked for providing access to drill core at Eskay Creek and the three samples used for geochemical analyses in this study. Special thanks go to Ravinder Sidhu (UofM) for supporting GJ at the SEM, Adrian Zhang, Huyun Zhou and Chris Gunning at SGS for their discussion on XRD results, Panseok Yang for his support during EMPA analysis, and to Ryan Sharpe for his assistance and support during SIMS preparation and analyses. The manuscript benefitted from discussion with James Macdonald and the constructive comments of two reviewers.

Conflicts of Interest: The authors declare no conflict of interest.

\section{References}

1. Board, W.S.; McLeish, D.F.; Greig, C.J.; Bath, O.E.; Ashburner, J.E.; Murphy, T.; Friedman, R.M. The brucejack Au-Ag deposit, Northwest British Columbia, Canada: Multistage porphyry to epithermal alteration, mineralization, and deposit formation in an island-arc setting. In Geology of the World's Major Gold Deposits and Provinces; Sillitoe, R.H., Goldfarb, R.J., Robert, F., Simmons, S.F., Eds.; Special Publication Number 23; The Society of Economic Geologists: Boulder, CO, USA, 2020; pp. $289-312$.

2. Childe, $\mathrm{F}$. U-Pb geochronology and $\mathrm{Nd}$ and $\mathrm{Pb}$ isotope characteristics of the Au-Ag-rich Eskay Creek volcanogenic massive sulfide deposit, British Columbia. Econ. Geol. 1996, 91, 1209-1224. [CrossRef]

3. Cutts, J.A.; McNicoll, V.J.; Zagorevski, A.; Anderson, R.G.; Martin, K. U-Pb geochronology of the Hazelton Group in the McTagg anticlinorium, Iskut River area, northwestern British Columbia. Geol. Fieldwork 2014, 2015-1, 87-101.

4. Gagnon, J.F.; Barresi, T.; Waldron, J.W.; Nelson, J.L.; Poulton, T.P.; Cordey, F. Stratigraphy of the upper Hazelton Group and the Jurassic evolution of the Stikine terrane, British Columbia. Can. J. Earth. Sci. 2012, 49, 1027-1052. [CrossRef]

5. Lewis, P.D. Geological maps of the Iskut river area, Northwest British Columbia $(104 \mathrm{~B} / 08,09,10$ \& part of 104B/01, 07, 11), 1:50,000-scale maps, legend and notes. Geosci. B. C. Rep. 2013, 5, 1.

6. Nelson, J.; Waldron, J.; van Straaten, B.; Zagorevski, A.; Rees, C. Revised stratigraphy of the Hazelton Group in the Iskut River region, northwestern British Columbia. Geol. Fieldwork 2018, 2018-1, 15-38.

7. Febbo, G.E.; Kennedy, L.A.; Nelson, J.L.; Savell, M.J.; Campbell, M.E.; Creaser, R.A.; Friedman, R.M.; van Straaten, B.I.; Stein, H.J. The evolution and structural modification of the supergiant mitchell au-cu porphyry, Northwestern British Columbia. Econ. Geol. 2019, 114, 303-324. [CrossRef]

8. Nelson, J.L.; Colpron, M.; Israel, S. The Cordillera of British Columbia, Yukon, and Alaska. In Tectonics, Metallogeny, and Discovery:The North American Cordillera and Similar Accretionary Settings; Colpron, M., Bissig, T., Rusk, B.G., Thompson, J.F.H., Eds.; Special Publication No. 17; The Society of Economic Geologists: Boulder, CO, USA, 2013; pp. 53-109.

9. Barresi, T.; Nelson, J.L.; Dostal, J.; Friedman, R.; Gibson, H. Evolution of the Hazelton arc near Terrace, British Columbia: Stratigraphic, geochronological, and geochemical constraints on a Late Triassic-Early Jurassic arc and Cu-Au porphyry belt. Can. J. Earth. Sci. 2015, 52, 466-494. [CrossRef]

10. Barresi, T.; Nelson, J.L.; Dostal, J. Geochemical constraints on magmatic and metallogenic processes: Iskut River Formation, volcanogenic massive sulfide-hosting basalts, NW British Columbia, Canada. Can. J. Earth Sci. 2015, 52, 1-20. [CrossRef] 
11. Bartsch, R.D. Eskay Creek area stratigraphy, update. Geol. Fieldwork 1993, 1992-1, 517-520.

12. Macdonald, A.J.; Lewis, P.D.; Thompson, J.F.H.; Nadaraju, G.; Bartsch, R.; Bridge, D.J.; Rhys, D.A.; Roth, T.; Kaip, A.; Godwin, C.I.; et al. Metallogeny of an early to middle jurassic arc, Iskut River area, northwestern British Columbia. Econ. Geol. 1996, 91, 1098-1114. [CrossRef]

13. Hart, T.R.; Gibson, H.L.; Lesher, C.M. Trace element geochemistry and petrogenesis of felsic volcanic rocks associated with volcanogenic massive $\mathrm{Cu}-\mathrm{Zn}-\mathrm{Pb}$ sulfide deposits. Econ. Geol. 2004, 99, 1003-1013. [CrossRef]

14. Gibson, H.; Galley, A. Volcanogenic Massive sulphide deposits of the Archean Noranda District, Quebec. In Mineral Deposits of Canada: A Synthesis of Major Deposit Types, District Metallogeny, the Evolution of Geological Provinces, and Exploration Methods; Goodfellow, W.D., Ed.; Special Publication No. 5; Mineral Deposits Division, Geological Association of Canada: St. John's, NL, Canada, 2007; pp. 533-552.

15. Piercey, S.J. An overview of the use of petrochemistry in the regional exploration for volcanogenic massive sulfide (VMS) deposits. In Proceedings of the Fifth Decennial International Conference on Mineral Exploration, Toronto, ON, Canada, 9-12 September 2007; pp. 223-246.

16. Piercey, S.J. An overview of petrochemistry in the regional exploration for volcanogenic massive sulphide (VMS) deposits. Geochem. Explor. Environ. Anal. 2010, 10, 119-136. [CrossRef]

17. Galley, A.; Hannington, M.; Jonasson, I. Volcanogenic massive sulphide deposits. In Mineral Deposits of Canada: A Synthesis of Major Deposit-Types, District Metallogeny, the Evolution of Geological Provinces, and Exploration Methods; Goodfellow, W.D., Ed.; Special Publication No. 5; Geological Association of Canada, Mineral Deposits Division: St. John's, NL, Canada, 2005; pp. 141-161.

18. Alldrick, D.J.; Nelson, J.L.; Barresi, T. Geology and mineral occurrences of the upper Iskut River area: Tracking the Eskay rift through northern British Columbia. Geol. Fieldwork 2005, 2004-2, 2-39.

19. Anderson, R.G. Anderson, R.G.A Mesozoic stratigraphic and plutonic framework for northwestern Stikinia (Iskut River area), northwestern British Columbia, Canada. In Mesozoic Paleogeography of the Western United States-II; Dunne, G.C., MacDougall, K.A., Eds.; Society of Economic Paleontologists and Mineralogists, Pacific Section: Tulsa, OK, USA, 1993; Volume 71, pp. 477-494.

20. Cas, R.A.F. Submarine volcanism; eruption styles, products, and relevance to understanding the host-rock successions to volcanic-hosted massive sulfide deposits. Econ. Geol. 1992, 87, 511-541. [CrossRef]

21. Gibson, H.; Morton, R.L.; Hudak, G.J. Submarine volcanic processes, deposits, and environments favorable for the loaction of volcanic-associated massive sulfide deposits. In Volcanic-Associated Massive Sulfide Deposits: Processes and Examples in Modern and Ancient Settings; Barrie, C.T., Hannington, M.D., Eds.; Society of Economic Geologists: Boulder, CO, USA, 1999; Volume 8, pp. 13-51.

22. Gibson, H.L.; Allen, R.L.; Riverin, G.; Lane, T.E. The VMS model: Advances and application to exploration targeting. In Proceedings of the Exploration 07: Fifth Decennial International Conference on Mineral Exploration, Toronto, ON, Canada, 9-12 September 2007; pp. 713-730.

23. Brueckner, S.M. Preliminary Geological and Geochemical Assessment of the A6 Anomaly as Potential Volcanogenic Massive Sulfide (VMS) Exploration Target; Personal Report: Vancouver, BC, Canada, 2020; p. 20.

24. Colpron, M.; Nelson, J.L.; Murphy, D.C. A tectonostratigraphic framework for the pericratonic terranes of the northern Canadian Cordillera. In Paleozoic Evolution and Metallogeny of Pericratonic Terranes at the Ancient Pacific Margin of North America, Canadian and Alaskan Cordillera; Colpron, M., Nelson, J., Eds.; GAC Special Paper: St. John's, NL, Canada, 2006; Volume 45, pp. 1-23.

25. Mihalynuk, M.G.; Nelson, J.; Diakow, L.J. Cache Creek terrane entrapment: Oroclinal paradox within the Canadian Cordillera. Tectonics 1994, 13, 575-595. [CrossRef]

26. Monger, J.W.H. Cordilleran tectonics: A Canadian perspective. Bull. Soc. Géol. France 1984, 26, 255-278. [CrossRef]

27. Monger, J.W.H.; Price, R.A. The Canadian Cordillera: Geology and tectonic evolution. Can. Soc. Explor. Geophys. Rec. 2002, 17-36.

28. Marsden, H.; Thorkelson, D.J. Geology of the Hazelton Volcanic Belt in British Columbia: Implications for the Early to Middle Jurassic Evolution of Stikinia. Tectonics 1992, 11, 1266-1287. [CrossRef]

29. Tipper, H.W.; Richards, T.A. Jurassic Stratigraphy and History of North-Central British Columbia; Bulletin 270; Geological Survey of Canada: Ottawa, ON, Canada, 1976.

30. Evenchick, C.A.; McNicoll, V.J.; Snyder, L.D. Stratigraphy, geochronology, and geochemistry of the Georgie River area, northwest British Columbia, and implications for mineral exploration. Can. J. Earth Sci. 2004, 41, 199-216. [CrossRef]

31. Evenchik, C.A.; Poulton, T.P.; McNicoll, V.J. Nature and significance of the diachronous contact between the Hazelton and Bowser Lake groups (Jurassic), north-central British Columbia. Bull. Can. Petrol. Geol. 2010, 58, 235-267. [CrossRef]

32. Cohen, K.M.; Finney, S.C.; Gibbard, P.L.; Fan, J.X. The ICS International Chronostratigraphic Chart. Episodes 2013, 36, 199-204. [CrossRef] [PubMed]

33. Nelson, J.; Kyba, J. Structural and stratigraphic control of porphyry and related mineralization in the Treaty Glacier-KSMBrucejack-Stewart trend of western Stikinia. Geol. Fieldwork 2014, 2014-1, 111-140.

34. Kirkham, R.V.; Margolis, J. Overview of the Sulphurets area, northwestern British Columbia. In Porphyry Deposits of the NorthWestern Cordillera of North America; Schroeter, T.G., Ed.; Special Volume 46; Canadian Institute of Mining, Metallurgy and Petroleum: Westmount, QC, Canada, 1995; pp. 473-483.

35. Macdonald, A.J. Lithostratigraphy and geochronometry, Brucejack Lake, northwestern British Columbia (104B/08E). Geol. Fieldwork 1993, 1993-1, 315-323. 
36. Barresi, T.; Nelson, J.L.; Alldrick, D.J.; Dostal, J. Pillow basalt ridge facies-detailed mapping of Eskay Creek equivalent stratigraphy. Geol. Fieldwork 2005, 2004-3, 41-52.

37. Sherlock, R.L.; Roth, T.; Spooner, E.T.C.; Bray, C.J. Origin of the Eskay Creek precious metal-rich volcanogenic massive sulfide deposit; fluid inclusion and stable isotope evidence. Econ. Geol. 1999, 94, 803-824. [CrossRef]

38. Kalanchey, R.; Elfen, S.; Weston, S.; Ulansky, S.; Dance, A.; Zurow, G.; Hamilton, W. Skeena Resources Limited, Eskay Creek Project, British Columbia, Canada: NI 43-101 Technical Report on Preliminary Economic Assessment; Ausenco Engineering Canada Inc.: Vancouver, BC, Canada, 2019; p. 364.

39. Barresi, T.; Dostal, J. Geochemistry and petrography of uppermost Hazelton Group volcanics: VHMS favourable stratigraphy in the Iskut River and Telegraph Creek map areas, northwest B.C. Geol. Fieldwork 2005, 2004-2, 30-40.

40. Barrett, T.J.; Sherlock, R.L. Geology, lithogeochemistry and volcanic setting of the Eskay Creek Au-Ag-Cu-Zn deposit, northwestern British Columbia. Explor. Min. Geol. 1996, 5, 339-368.

41. Roth, T.; Thompson, J.F.H.; Sillitoe, R.H. The precious metal-rich Eskay Creek deposit, northwestern British Columbia. In Volcanic-Associated Massive Sulfide Deposits: Processes and Examples in Modern and Ancient Settings; Barrie, C.T., Hannington, M.D., Eds.; Society of Economic Geologists: Littleton, CO, USA, 1999; Volume 8, pp. 357-373.

42. Febbo, G.E.; Kennedy, L.A.; Savell, M.; Creaser, R.A.; Friedman, R.M. Geology of the Mitchell Au-Cu-Ag-Mo porphyry deposit, northwestern British Columbia, Canada. Geol. Fieldwork 2015, 2015-1, 59-86.

43. Margolis, J. Geology and intrusion-related copper-gold mineralization, Sulphurets, British Columbia. Ph.D Thesis, University of Oregon, Eugene, OR, USA, 1993.

44. Tombe, S.P.; Richards, J.P.; Greig, C.J.; Board, W.S.; Creaser, R.A.; Muehlenbachs, K.A.; Larson, P.B.; DuFrane, S.A.; Spell, T. Origin of the high-grade Early Jurassic Brucejack epithermal Au-Ag deposits, Sulphurets Mining Camp, northwestern British Columbia. Ore. Geol. Rev. 2018, 95, 480-517. [CrossRef]

45. Pretivm Resouces Inc. U-Pb Geochronology on the Bowser Property; Pretivm Resouces Inc.: Vancouver, BC, Canada, 2020 ; p. 20.

46. Pouchou, J.L.; Pichoir, F. A new model for quantitative X-ray microanalysis, Part II: Application to in depth analysis of heterogeneous samples. Rech. Aérosp. 1984, 5, 349-367.

47. Riciputi, L.R.; Paterson, B.A.; Ripperdan, R.L. Measurement of light stable isotope ratios by SIMS: Matrix effects for oxygen, carbon, and sulfur isotopes in minerals. Int. J. Mass. Spec. 1998, 178, 81-112. [CrossRef]

48. Coplen, T.B. Guidelines and recommended terms for expression of stable-isotope-ratio and gas-ratio measurement results. Rapid Commun. Mass Spectrom. 2011, 25, 2538-2560. [CrossRef] [PubMed]

49. Coplen, T.B. Reporting of stable hydrogen, carbon, and oxygen isotopic abundances (Technical Report). Pure Appl. Chem. 1994, 66, 273-276. [CrossRef]

50. Coplen, T.B. Report of Stable Isotopic Composition Reference Material VSMOW (Hydrogen and Oxygen Isotopes in Water); United States Geological Survey, Reston Stable Isotope Laboratory: Reston, VA, USA, 2020; p. 4.

51. Gonfiantini, R. Standards for stable isotope measurements in natural compounds. Nature 1978, 271, 534-536. [CrossRef]

52. Kelly, J.L.; Fu, B.; Kita, N.T.; Valley, J.W. Optically continuous silcrete quartz cements of the St. Peter Sandstone: High precision oxygen isotope analysis by ion microprobe. Geochim. Cosmochim. Acta 2007, 71, 3812-3832. [CrossRef]

53. Ross, P.-S.; Bédard, J.H. Magmatic affinity of modern and ancient subalkaline volcanic rocks determined from trace-element discriminant diagrams. Can. J. Earth Sci. 2009, 46, 823-839. [CrossRef]

54. Rollinson, H.R. Using Geochemical Data: Evaluation, Presentation, Interpretation; Longman Scientific and Technical: London, UK, 1993.

55. Boynton, W.V. Geochemistry of Rare Earth Elements: Meteorite Studies. In Rare Earth Element Geochemistry; Henderson, P., Ed.; Elsevier: New York, NY, USA, 1984; pp. 63-114. [CrossRef]

56. Nakamura, N. Determination of REE, Ba, Fe, Mg, Na and $\mathrm{K}$ in carbonaceous and ordinary chondrites. Geochim. Cosmochim. Acta 1974, 38, 757-775. [CrossRef]

57. Pearce, J.A. A User's Guide to Basalt Discrimination Diagrams. In Trace Element Geochemistry of Volcanic Rocks: Applications for Massive Sulphide Exploration; Wyman, D.A., Ed.; Short Course Notes; Geological Assocaition of Canada: St. John's, NL, Canada, 1996; Volume 12, pp. 79-113.

58. Sun, S.S.; McDonough, W.F. Chemical and isotopic systematics of oceanic basalts: Implications for mantle composition and processes. Geol. Soc. Spec. Publ. 1989, 42, 313-345. [CrossRef]

59. Johnson, G. Alteration Mineralogy and Chemistry of Felsic Volcanic Flows of the Jurassic Iskut River Formation at the A6 Anomaly, North-Central British Columbia; University of Manitoba: Winnipeg, MB, Canada, 2021.

60. Battaglia, S. Variations in the chemical composition of illite from five geothermal fields: A possible geothermometer. Clays Clay Miner. 2004, 39, 501-510. [CrossRef]

61. Meunier, A.; El Albani, A. The glauconite-Fe-illite-Fe-smectite problem: A critical review. Terra Nova 2007, 19, 95-104. [CrossRef]

62. López-Quirós, A.; Sánchez-Navas, A.; Nieto, F.; Escutia, C. New insights into the nature of glauconite. Am. Min. 2020, 105, 674-686. [CrossRef]

63. Rieder, M.; Cavazzini, G.; D’yakonov, Y.S.; Frank-Kamenetskii, V.A.; Gottardi, G.; Guggenheim, S.; Koval', P.W.; Müller, G.; Neiva, A.M.R.; Radoslovich, E.W.; et al. Nomenclature of the Micas. Clays Clay Miner. 1998, 46, 586-595. [CrossRef]

64. Rosenberg, P.E. The nature, formation, and stability of end-member illite: A hypothesis. Am. Min. 2002, 87, 103-107. [CrossRef]

65. Aja, S.U. A Hydrothermal Study of Illite Stability Relationships between 25 and $250{ }^{\circ} \mathrm{C}$ and Pv $1 / 4 \mathrm{PH} 2 \mathrm{O}$; Washington State University: Washington, DC, USA, 1989. 
66. Aja, S.U. On the Thermodynamic Stability of Illite and I-S Minerals. Clays Clay Miner. 2020, 67, 518-536. [CrossRef]

67. Meunier, A.; Velde, B. Solid solutions in I/S mixed-layer minerals and illite. Am. Min. 1989, 74, 1106-1112.

68. Środoń, J.; Elsass, F.; McHardy, W.J.; Morgan, D.J. Chemistry of illite-smectite inferred from TEM measurements of fundamental particles. Clay Miner. 1992, 27, 137-158. [CrossRef]

69. Yates, D.M.; Rosenberg, P.E. Formation and stability of end-member illite: II. Solid equilibration experiments at 100 to $250{ }^{\circ} \mathrm{C}$. and

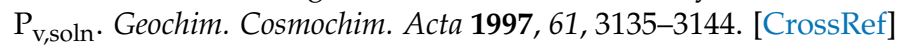

70. Reich, M.; Kesler, S.E.; Utsonomiya, S.; Palenik, C.S.; Chryssoulis, S.; Ewing, R.C. Solubility of gold in arsenian pyrite. Geochim. Cosmochim. Acta 2005, 69, 2781-2796. [CrossRef]

71. Newman, A.C.D.; Brown, G. The chemical constitution of clays. In Chemistry of Clays Clay Min; Newman, A.C.D., Ed.; Monograph No. 6; Longman Scientific and Technical: London, UK, 1987; pp. 1-128.

72. International Mineralogical Association. The New IMA List of Minerals-A Work in Progress 2021. Available online: http: / / cnmnc.main.jp/ (accessed on 28 May 2021).

73. Hokka, J. Geology, alteration and lithogeochemistry of the Paleoproterozoic Korpela VMS occurrence in Eastern Finland. Min. Dep. 2020, 55, 1581-1604. [CrossRef]

74. Lesher, C.M.; Goodwin, A.M.; Campbell, I.H.; Gorton, M.P. Trace-element geochemistry of ore-associated and barren, felsic metavolcanic rocks in the Superior Province, Canada. Can. J. Earth Sci. 1986, 23, 222-237. [CrossRef]

75. Lentz, D.R. Petrogenetic evolution of felsic volcanic sequences associated with Phanerozoic volcanic-hosted massive sulphide systems: The role of extensional geodynamics. Ore. Geol. Rev. 1998, 12, 289-327. [CrossRef]

76. Lentz, D.; Goodfellow, W. Re-evaluation of the petrochemistry of felsic volcanic and volcaniclastic rocks near the Brunswick No.6 and 12 massive sulphide deposits, Bathurst Mining Camp, New Brunswick. In Current Research-Part E; Paper 92-1 E; Geological Survey of Canada: Ottawa, ON, Canada, 1992; pp. 343-350.

77. Pilote, J.-L.; Piercey, S.J. Petrogenesis of the Rambler Rhyolite Formation: Controls on the Ming VMS Deposit and geodynamic implications for The Taconic Seaway, Newfoundland Appalachians, Canada. Am. J. Sci. 2018, 318, 640-683. [CrossRef]

78. Pilote, J.-L.; Piercey, S.J.; Mercier-Langevin, P. Evolution of the subseafloor hydrothermal system associated with the Ming VMS deposit, Newfoundland Appalachians, and its controls on base and precious metal distribution. Min. Dep. 2019, 55, 913-936. [CrossRef]

79. Campbell, I.H.; Coad, P.; Franklin, J.M.; Gorton, M.P.; Scott, S.D.; Sowa, J.; Thurston, P.C. Rare earth elements in volcanic rocks associated with $\mathrm{Cu}-\mathrm{Zn}$ massive sulphide mineralization: A preliminary report. Can. J. Earth Sci. 1982, 19, 619-623. [CrossRef]

80. Campbell, I.H.; Franklin, J.M.; Gorton, M.P.; Hart, T.R.; Scott, S.D. The role of subvolcanic sills in the generation of massive sulfide deposits. Econ. Geol. 1981, 76, 2248-2253. [CrossRef]

81. Franklin, J.M.; Lydon, J.W.; Sangster, D.F. Volcanic-associated sulfide deposits. In Econ. Geol. Seventy-Fifth Anniversary Volume; Skinner, B.J., Ed.; Society of Economic Geologists: Littleton, CO, USA, 1981; pp. 485-627.

82. Lydon, J.W. Volcanogenic massive sulphide deposits Part 2: Genetic models. Geosci. Can. 1988, 15, 43-65.

83. Leat, P.T.; Jackson, S.E.; Thorpe, R.S.; Stillman, C.J. Geochemistry of bimodal basalt-subalkaline/peralkaline rhyolite provinces within the Southern British Caledonides. J. Geol. Soc. 1986, 143, 259-273. [CrossRef]

84. Pearce, J.A.; Harris, N.B.W.; Tindle, A.G. Trace element discrimination diagrams for the tectonic interpretation of granitic rocks. J Petrol. 1984, 25, 956-983. [CrossRef]

85. Barrie, C.T.; Hannington, M.D. Classification of volcanic-associated massive sulfide deposits based on host-rock composition. In Volcanic-Associated Massive Sulfide Deposits: Processes and Examples in Modern and Ancient Settings; Barrie, C.T., Hannington, M.D., Eds.; Society of Economic Geologists: Littleton, CO, USA, 1999; Volume 8, pp. 1-11.

86. Franklin, J.M.; Gibson, H.L.; Jonasson, I.R.; Galley, A.G. Volcanogenic massive sulfide deposits. In Econ. Geol. 100th Anniversary Volume, 1905-2005; Hedenquist, J.W., Thompson, J.F.H., Goldfarb, R.J., Richards, J.P., Eds.; Society of Economic Geologists: Littleton, CO, USA, 2005; pp. 523-560.

87. Pearce, J.A. Immobile Element Fingerprinting of Ophiolites. Elements 2014, 10, 101-108. [CrossRef]

88. Rudnick, R.L.; Gao, S. Composition of the continental crust. In Treatise on Geochemistrty: The Crust; Rudnick, R.L., Ed.; Elsevier: Amsterdam, The Netherlands, 2003; Volume 3, pp. 1-64.

89. Shervais, J.W. Ti-V plots and the petrogenesis of modern and ophiolitic lavas. Earth Plan. Sci. Let. 1982, 59, 101-118. [CrossRef]

90. Pearce, J.A. Geochemical fingerprinting of oceanic basalts with applications to ophiolite classification and the search for Archean oceanic crust. Lithos 2008, 100, 14-48. [CrossRef]

91. Cabanis, B.; Lecolle, M. Le diagramme La/10-Y/15-Nb/8: Un outil pour la discrimination des séries volcaniques et la mise en évidence des processus de mélange et/ou de contamination crustale. Compt. Rend. Acad. Sci. 1989, 309, $2023-2029$.

92. Alldrick, D.J.; Stewart, M.L.; Nelson, J.L.; Simpson, K.A. Tracking the Eskay rift through northern British Columbia-geology and mineral occurrences of the Upper Iskut River area. Geol. Fieldwork 2003 2004, 1-18.

93. Hannington, M.D. Volcanogenic Massive Sulfide Deposits. In Treatise on Geochemistry: Geochemistrty of Mineral Deposits; Scott, S.D., Ed.; Elsevier: Amsterdam, The Netherlands, 2014; Volume 13, pp. 463-488.

94. Hannington, M.D.; De Ronde, C.E.J.; Petersen, S. Sea-floor tectonics and submarine hydrothermal systems. In Econ. Geol. 100th Anniversary Volume, 1905-2005; Hedenquist, J.W., Thompson, J.F.H., Goldfarb, R.J., Richards, J.P., Eds.; Society of Economic Geologists: Littleton, CO, USA, 2005; pp. 111-141. 
95. Gifkins, C.; Herrmann, W.; Large, R. Altered Volcanic Rocks: A Guide to Description and Interpretation; Centre of Ore Deposit Research: Hobart, Tasmania, 2005.

96. Thompson, A.J.B.; Thompson, J.F.H. Atlas of Alteration-A field and Petrographic Guide to Hydrothermal Alteration Minerals; Mineral Deposit Division, Geological Association of Canada: St. John's, NL, Canada, 1996.

97. Goodfellow, W.D. Metallogeny of the Bathurst Mining Camp, northern New Brunswick. In Mineral Deposits of Canada: A Synthesis of Major Deposit Types, District Metallogeny, the Evolution of Geological Provinces, and Exploration Methods; Goodfellow, W.D., Ed.; Special Publication No. 5; Mineral Deposits Division, Geological Association of Canada: St.John's, NL, Canada, 2007 ; pp. 449-469.

98. Large, R.R.; Gemmell, J.B.; Paulick, H.; Huston, D.L. The alteration box plot: A Simple approach to understanding the relationship between alteration mineralogy and lithogeochemistry associated with volcanic-hosted massive sulfide deposits. Econ. Geol. 2001, 96, 957-971. [CrossRef]

99. Lentz, D.; Goodfellow, W.D. Character, distribution, and origin of zoned hydrothermal alteration features at the Brunswick No. 12 massive sulphide deposit, Bathurst Mining Camp, New Brunswick. In Current Research; Abbott, S.A., Ed.; Information Circular 94-1; New Brunswick Department of Natural Resources and Energy, Minerals Resources: Fredericton, NB, Canada, 1994; pp. 94-119.

100. Grant, J.A. The isocon diagram-A simple solution to Gresens equation for metasomatic alteration. Econ. Geol. 1986, 81, 1976-1982. [CrossRef]

101. Grant, J.A. Isocon analysis: A brief review of the method and applications. Phys. Chem. Earth Parts A/B/C 2005, 30, 997-1004. [CrossRef]

102. Gresens, R.L. Composition-volume relationships of metasomatism. Chem. Geol. 1967, 2, 47-65. [CrossRef]

103. Maclean, W.H. Mass Change Calculations in Altered Rock Series. Min. Dep. 1990, 25, 44-49. [CrossRef]

104. MacLean, W.H.; Barrett, T.J. Lithogeochemical techniques using immobile elements. J. Geochem. Explor. 1993, 48, 109-133. [CrossRef]

105. Davies, J.F.; Whitehead, R.E. Alkali-Alumina and MgO-Alumina Molar Ratios of Altered and Unaltered Rhyolites. Explor. Min. Geol. 2006, 15, 75-88. [CrossRef]

106. Ishikawa, Y.; Sawaguchi, T.; Iwaya, S.; Horiuchi, M. Delineation of prospecting targets for Kuroko deposits based on modes of volcanism of underlying dacite and alteration haloes. Min. Geol. 1976, 26, 105-117.

107. Inoue, A.; Utada, M. Further investigations of a conversion series of dioctahedral mica/smectites in the Shinzan hydrothermal alteration area, northeast Japan. Clays Clay Miner. 1983, 31, 401-412. [CrossRef]

108. Sharp, Z.D.; Gibbons, J.A.; Maltsev, O.; Atudorei, V.; Pack, A.; Sengupta, S.; Shock, E.L.; Knauth, L.P. A calibration of the triple oxygen isotope fractionation in the $\mathrm{SiO} 2-\mathrm{H} 2 \mathrm{O}$ system and applications to natural samples. Geochim. Cosmochim. Acta 2016, 186, 105-119. [CrossRef]

109. Sheppard, S.M.F.; Gilg, H.A. Stable isotope geochemistrty of clay minerals. Clay Min. 1996, 31, 1-24. [CrossRef]

110. Vho, A.; Lanari, P.; Rubatto, D. An Internally-Consistent Database for Oxygen Isotope Fractionation between Minerals. J. Petrol. 2019, 60, 2101-2129. [CrossRef]

111. Mathieu, L. Quantifying Hydrothermal Alteration: A Review of Methods. Geosciences 2018, 8, 245. [CrossRef]

112. Leitch, C.H.B.; Lentz, D.R. The Gresens approach to mass balance constraints of alteration systems: Methods, pitfalls, examples. In Alteration and Alteration Processes Associated with Ore-forming Systems; Lentz, D.R., Ed.; Geological Association of Canada: St. John's, NL, Canada, 1994.

113. Sarbas, B.; Nohl, U. The GEOROC database as part of a growing geoinformatics network. In Proceedings of the Geoinformatics Conference, Potsdam, Germany, 11-13 June 2008; pp. 42-43.

114. Mukherjee, P.K.; Gupta, P.K. Arbitrary scaling in ISOCON method of geochemical mass balance: An evaluation of the graphical approach. Geochem. J. 2008, 42, 247-253. [CrossRef]

115. Gill, S.B.; Piercey, S.J.; Layton-Matthews, D.; Layne, G.D.; Piercey, G. Mineralogical, sulphur, and lead isotopic study of the Lemarchant $\mathrm{Zn}-\mathrm{Pb}-\mathrm{Cu}-\mathrm{Ag}-\mathrm{Au}-\mathrm{VMS}$ deposit: Implications for precious-metal enrichment processes in the VMS environment. In Targeted Geoscience Initiative 4: Contributions to the Understanding of Volcanogenic Massive Sulphide Deposit Genesis and Exploration Methods Development; Peter, J.M., Mercier-Langevin, P., Eds.; Open File 7853; Geological Survey of Canada: Ottawa, ON, Canada, 2015; pp. 183-195.

116. Large, R.R. Australian volcanic-hosted massive sulfide deposits: Features, styles, and genetic models. Econ. Geol. 1992, 87, 471-510. [CrossRef]

117. Galley, A.G. Characteristics of semi-conformable alteration zones associated with volcanogenic massive sulphide districts. J. Geochem. Explor. 1993, 48, 175-200. [CrossRef]

118. Shanks III, W.C.; Thurston, R. Scientific Investigations Report 2010-5070-C; Volcanogenic Massive Sulfide Occurrence Model; U.S. Geological Survey: Reston, VA, USA, 2012; p. 345.

119. Inoue, A. Formation of clay minerals in hydrothermal environments. In Origin and Mineralogy of Clays; Velde, B., Ed.; Springer: Berlin/Heidelberg, Germany, 1995; pp. 268-329. [CrossRef]

120. Bowers, T.S.; Jackson, K.J.; Helgeson, H.C. Equilibrium Activity Diagrams; Springer: Berlin/Heidelberg, Germany, 1984. [CrossRef]

121. Arndt, N.T.; Fontboté, L.; Hedenquist, J.W.; Kesler, S.E.; Thompson, J.F.H.; Wood, D.G. Future Global Mineral Resources. Geochem. Perspect. 2017, 6, 1-171. [CrossRef]

122. Fulignati, P. Clay Minerals in Hydrothermal Systems. Minerals 2020, 10, 919. [CrossRef] 
123. Pirajno, F. Hydrothermal Processes and Wall Rock Alteration. In Hydrothermal Processes and Mineral Systems; Pirajno, F., Ed.; Springer: Dordrecht, The Netherlands, 2009; pp. 73-164. [CrossRef]

124. Środoń, J.; Eberl, D.D. Illite. Rev. Mineral. 1984, 13, 495-544. [CrossRef]

125. Steiner, A. Clay Minerals in Hydrothermally Altered Rocks at Wairakei, New Zealand. Clays Clay Miner. 1968, 16, 193-213. [CrossRef]

126. Inoue, A.; Lanson, B.; Marques-Fernandes, M.; Sakharov, B.A.; Murakami, T.; Meunier, A.; Beaufort, D. Illite-smectite mixed-layer minerals in the hydrothermal alteration of volcanic rocks: I. One-dimensional XRD structure analysis and characterization of component layers. Clays Clay Miner. 2005, 53, 423-439. [CrossRef]

127. Riegler, T.; McClenaghan, S.H. Authigenic potassic silicates in the Rathdowney Trend, southwest Ireland: New perspectives for ore genesis from petrography of gangue phases in Irish-type carbonate-hosted $\mathrm{Zn}-\mathrm{Pb}$ deposits. Ore. Geol. Rev. 2017, 88, 140-155. [CrossRef]

128. Anderson, M.O.; Hannington, M.D.; McConachy, T.F.; Jamieson, J.W.; Anders, M.; Wienkenjohann, H.; Strauss, H.; Hansteen, T.; Petersen, S. Mineralization and Alteration of a Modern Seafloor Massive Sulfide Deposit Hosted in Mafic Volcaniclastic Rocks. Econ. Geol. 2019, 114, 857-896. [CrossRef]

129. Cagatay, M.N. Hydrothermal alteration associated with volcanogenic massive sulfide deposits: Examples for Turkey. Econ. Geol. 1993, 88, 606-621. [CrossRef]

130. Graham, G.E.; Kokaly, R.F.; Kelley, K.D.; Hoefen, T.M.; Johnson, M.R.; Hubbard, B.E. Application of Imaging Spectroscopy for Mineral Exploration in Alaska: A Study over Porphyry Cu Deposits in the Eastern Alaska Range. Econ. Geol. 2018, 113, 489-510. [CrossRef]

131. Gregory, R.T.; Criss, R.E. Isotopic Exchange in open and closed systems. Rev. Min. Geochem. 1986, 16, 91-127.

132. Gregory, R.T.; Criss, R.E.; Taylor Jr., H.P. Oxygen isotope exchange kinetics of mineral pairs in closed and open systems: Applications to problems of hydrothermal alteration of igneous rocks and Precambrian iron formations. Chem. Geol. 1989, 75, 1-42. [CrossRef]

133. Eslinger, E.V.; Savin, S.M. Mineralogy and oxygen isotope geochemistry of the hydrothermally altered rocks of the OhakiBroadlands, New Zealand, geothermal area. Am. J. Sci. 1973, 273, 240-267. [CrossRef]

134. Shanks III, W.C.P. Stable Isotope Geochemistry of Mineral Deposits. In Treatise on Geochemistry: Geochemistry of Mineral Deposit; Scott, S.D., Ed.; Elsevier: Amsterdam, The Netherlands, 2014; Volume 13, pp. 59-85.

135. Jean-Baptiste, P.; Charlou, J.L.; Stievenard, M. Oxygen isotope study of mid-ocean ridge hydrothermal fluids: Implication for the oxygen-18 budget of the oceans. Geochim Cosmochim Acta 1997, 61, 2669-2677. [CrossRef]

136. Ohmoto, H. Geologic setting of the Kuroko deposits, Japan: Part, I. Geologic history of the Green Tuff region. In The Kuroko and Related Volcanogenic Massive Sulfide Deposits; Ohmoto, H., Skinner, B.J., Eds.; Econ Geol Monograph No. 5; The Society of Economic Geologists: Littleton, CO, USA, 1983; pp. 9-24.

137. Ohmoto, H. Formation of volcanogenic massive sulfide deposits: The Kuroko perspective. Ore. Geol. Rev. 1996, 10, 135-177. [CrossRef]

138. Lentz, D.R.; Goodfellow, W.D. Intense silicification of footwall sedimentary rocks in the stockwork alteration zone beneath the Brunswick No. 12 massive sulphide deposit, Bathurst, New Brunswick. Can. J. Earth Sci. 1996, 33, 284-302. [CrossRef]

139. Piercey, S.J.; Peter, J.M.; Goodfellow, W.D.; Herrington, R.M. Zinc-rich volcanogenic massive sulfide (VMS) deposits. In Proceedings of the Abstract Zinc Conference, Cork, Ireland, 10-14 September 2010; p. 4.

140. Schardt, C.; Large, R.R. New insights into the genesis of volcanic-hosted massive sulfide deposits on the seafloor from numerical modeling studies. Ore. Geol. Rev. 2009, 35, 333-351. [CrossRef] 